\title{
Abastecimiento urbano, mercado local y control municipal: La provisión y comercialización de la carne en Burgos (siglo Xv)
}

\author{
Juan A. Bonachia Hernando *
}

\section{INTRODUCCIÓN}

Hasta hace muy pocas fechas, el problema del abastecimiento urbano era una parcela de la historia bajomedieval burgalesa prácticamente yerma. Todo lo más que se podia encontrar, tras un profundo rastreo a través de la producción historiográfica de autores y eruditos locales, no eran sino algunas breves noticias, por lo demás bastante parciales y deslabazadas. Es por eso que en un articulo escrito hace algunos años avisaba sobre la necesidad de abordar el análisis del mercado interior y señalaba que, sin duda, "la relevancia otorgada al tráfico internacional se correspondia con un cierto abandono en la profundización del estudio del comercio local»'.

Sin embargo, esas palabras deberian ser bastante matizadas en la actualidad. Sin que la cuestión haya sido abordada de una forma monográfica y global, no es menos cierto que algunas de las más recientes investigaciones, aparecidas a la luz en el último decenio, han prestado una considerable mayor atención al problema. Caben ser destacados en ese sentido las primeras aportaciones realizadas por mi mismo asi como por

* Dpto. H. Medieval. Universidad de Valladolid.

' Bonachia Hernando, J. A., "Algunas cuestiones en torno al estudio de la sociedad bajomedieval burgalesa", en La Ciudad de Burgos. Actas del Congreso de Historia de Burgos. Madrid 1985, págs. 59-82, en concreto, pág. 64 . 
Y. Guerrero Navarrete e H. Casado Alonso ${ }^{2}$. En lo referente, en concreto, al abastecimiento y comercialización de la carne en Burgos debo hacer mención, necesariamente, del espléndido trabajo de E. Hernández Esteve que, si bien sobrepasa los limites cronológicos estrictamente académicos, ofrece un completo modelo para el análisis del avituallamiento y consumo cárnico de cualquier centro urbano de época bajomedieval ${ }^{3}$.

No parece, por otra parte, que este problema haya sido muy estudiado en otras ciudades españolas. No obstante, también cabe señalar aqui una relativa proliferación de estudios en los últimos tiempos, bien sea a través de aproximaciones monográficas a los problemas de abastecimiento y consumo en determinadas localidades, bien mediante capitulos dedicados ex profeso a la cuestión en investigaciones sobre ciudades y concejos medievales ${ }^{4}$. Por lo que concierne, en particular, a la comercialización

Guerrero Navarrete, Y., Organización y gobierno en Burgos durante el reinado de Enrique IV de Castilla. 1453-1476. Madrid 1986, en especial págs. 317-383. Idem, "La economia de Burgos en la Edad Media", en Historia de Burgos. II: Edad Media (1). Burgos 1986, págs. 425-485. Casado Alonso, H., Señores, mercaderes y campesinos. La comarca de Burgos a fines de la Edad Media. León 1987, en concreto, págs. 210 ss. Bonachia Hernando, J. A., en VV.AA., Burgos en la Edad Media. Valladolid 1984, págs. 296-317.

${ }^{3}$ Hernandez Esteve, E., Noticia del abastecimiento de carne en la ciudad de Burgos (15361537). Libro Mayor del Obligado de las Carnicerias (En prensa. Trabajo realizado para "The Sixth World Congress of Accounting Historians". Kyoto, agosto-1992, que he conocido por amabilidad del autor, a quien públicamente agradezco su deferencia).

${ }^{4}$ VV.AA., Bizcaya en la Edad Media, San Sebastián 1985, t. II, págs. 302 y ss. ARIzAGA Bolumburu, B., "El abastecimiento de las vilias vizcainas medievales: politica comercial de las villas respecto al entorno y a su interior", en La Ciudad Hispánica durante los siglos xIII al $x \%$. Madrid 1985, t. I, págs. 293-316. ldem, "La alimentación en el Pais Vasco en la Baja Edad Media: el caso de Guipúzcoa», en Manger et boire au Moyen Age. Nice 1984, t. II, págs. 197-208, y, en general, los dos volúmenes de este Congreso. GonzAlez Minguez, C., "Algunos aspectos del abastecimiento de Vitoria en la Edad Media", en Vitoria en la Edad Media. Actas del / Congreso de Estudios Históricos. Vitoria 1982, págs. 562-602. PRIETo BANCES, R., “El abasto de Oviedo en el siglo xiv y sus problemas". Homenaje a don Ramón Carande. Madrid 1963, t. Il, págs. 357-380. MACKAY, A., "Comercio-mercado interior y la expansión económica del siglo xv", en Actas del I/ Coloquio de Historia Medieval Andaluza. Sevilla 1982, págs. 103-123. Monsalvo Antón, J. M. ${ }^{\star}$, El sistema politico concejil. El ejemplo del señorio medieval de Alba de Tormes y su Concejo de Villa y Tierra. Salamanca 1988. págs. 441-489. Martín CEA, J. Carlos, El mundo rural castellano a fines de la Edad Media. El ejemplo de Paredes de Nava en el siglo xv. Valladolid 1991, págs. 303 y ss. GonzALEz JimÉnEz, M., El Concejo de Carmona a fines de la Edad Media (1464-1523). Sevilla 1973. AsENJo GonzAl.ez, M., Segovia. La Ciudad y su Tierra a fines del Medievo. Segovia 1986, págs. 217-258. Ladero Quesada, M. F., La ciudad de Zamora en la época de los Reyes Católicos. Economia y gobierno. Zamora 1991, págs. 54-85. Luis López, C., La Comunidad de Villa y Tierra de Piedrahita en el tránsito de la Edad Media a la Moderna. Ávila 1987, págs. 443-462. ARGENTE del CAstillo, C., La ganaderia medieval andaluza. Siglos xil-xvi (Reinos de Jaén y Córdoba), Jaén 1991. Bennassar, B., Valladolid en el siglo de oro. Una ciudad de Castilla y su entorno agrario en el siglo xvi. Valladolid 1983, págs. 55 ss. YUN CASALILLA, B., Crisis de subsistencias y conflictividad social en Córdoba a principios del siglo xvi. Córdoba 1980. SanCHEZ Benito, 
Abastecimiento urbano, mercado local y control municipal: ...

de la carne, la producción es escasa aunque contamos con muy interesantes análisis sobre las carnicerías de algunos núcleos como Segovia, Murcia y Cuenca ${ }^{5}$.

Este trabajo pretende presentar, en el contexto más amplio de un estudio general sobre mercado interior, abastecimiento urbano y consumo en Burgos durante la Baja Edad Media, una panorámica de los problemas sugeridos por el aprovisionamiento y comercio de carne en esta ciudad, incorporando las ricas aportaciones de los autores anteriormente citados y exponiendo, en la medida que lo permiten las fuentes, una visión global del problema durante la última centuria medieval. A lo largo de él se podrán ofrecer datos referidos a los procedimientos utilizados en esos momentos para atender al avituallamiento y venta de este producto en Burgos, los protagonistas (individuos e instituciones) implicados en ello, los lugares y precios de venta de la carne, las normas municipales que regulan las transacciones, etc..., aspectos que, ciertamente, no manifiestan diferencias sustanciales con el cuadro ofrecido por las restantes ciudades castellanas a fines de la Edad Media. De otra parte, un análisis de todas estas cuestiones penetrará inevitablemente en una compleja casuistica que trasciende los asuntos anteriormente citados; así, aparecen planteados o sugeridos al menos problemas tan variados como los referentes a la propiedad urbana, la organización municipal de los pastizales y su aprovechamiento por los abastecedores o la política fiscal y los medios de obtención de renta por el Concejo.

\section{CONTROL DEL ABASTECIMIENTO E INTERVENCIONISMO DE LOS CONCEJOS}

Como ya se ha dicho en múltiples ocasiones ${ }^{5}$, la necesidad cotidiana y primordial de procurarse alimentos que cualquier individuo debe satis-

\footnotetext{
J. M., "Crisis de abastecimientos y administración concejil. Cuenca, 1499-1509", en En la España Medieval, 14. Madrid 1991, págs. 275-306, etc... Dada la identidad de los problemas planteados en los diversos núcleos evitaré reincidir innecesariamente en la bibliografía apuntada.

${ }^{5}$ Aguade S. y Cabañas, M." D., "Comercio y sociedad urbana en la Castilla Medieval. La comercialización de la carne en Cuenca (1177-1500), AEM., 14, 1984, págs. 487-516. Marin Garcla, M." Ángeles, "Las carnicerias y el abastecimiento de carne en Murcia (1450-1500)", Miscelánea Medieval Murciana, 14,1987-1988, págs. 51-99. Grau, M., "Las carnicerias de Segovia en el siglo xv", Polvo de Archivos, 2. "Serie. Segovia 1967, págs. 15-23.

${ }^{6}$ Sirvan como ejempio, Martin Cea, J. C., El mundo rural..., pág. 303. Arizaga Bolumburu, B., "La comida en Guipúzcoa en el siglo xv», Homenaje a J. Ignacio Tellechea Idigoras, 16 17, I, 1982-1983, págs. 176-194.
} 
facer para asegurar su supervivencia es, durante la Edad Media, más allá de cualquier otra consideración, un problema. La extrema dependencia de las condiciones naturales, el empleo de unos recursos técnicos atrasados y débiles, y unos rendimientos y productividad de la tierra escasos ofrecen como resultado la amenaza persistente y tenaz de carestias y desabastecimientos $y$, en consecuencia, el perenne temor del ser humano a las crisis periódicas de subsistencias y al hambre. La alimentación, la necesidad de proveerse de recursos suficientes para sobrevivir, se transforma, por consiguiente, en una obsesión sentida de modo acuciante por todos los individuos de la sociedad medieval. Burgos, como otras muchas ciudades, no es una excepción. En la mente del hombre burgalés de los siglos XIV y XV, el aprovisionamierito de la urbe no es tari sólo un factor elemental para su subsistencia sino que se erige también en un motivo de preocupación cotidiana.

Por otro lado, la precariedad, debilidad e imperfección de la estructura del mercado local en una economia precapitalista hacen necesaria la intervención del poder politico como mecanismo regulador de los previsibles desajustes entre oferta, demanda y precios '. Como consecuencia, por lo tanto, se genera un fuerte intervencionismo de los concejos en todo el proceso de circulación y consumo de mercancias, asi como un progresivo y cada vez más perfeccionado y rigido control sobre todas las transacciones ${ }^{8}$.

Habida cuenta de todas estas premisas, no es nada extraño que el abastecimiento urbano se transformara en una de las cuestiones que mayor actividad reguladora generó desde el aparato administrativo concejil. Por eso mismo, los Libros de Actas municipales se convierten en una fuente de información excepcional a partir de la cual pueden ser abordados aspectos tan interesantes como la demanda ciudadana de artículos de consumo y de primera necesidad, la mayor o menor influencia de las contingencias externas en la estabilidad del mercado, los establecimientos y lugares de compraventa, mercados y ferias, la infraestructura comercial urbana y su transformación en el interior del perimetro amurallado, los nexos entre el sistema fiscal municipal, el desarrollo mercantil y el consumo, la regulación municipal del comercio interior y otros muchos ${ }^{9}$. En resumen, esa preocupación por el aprovisionamiento, per-

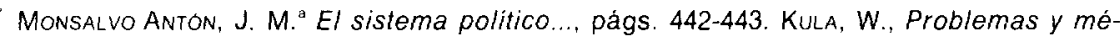
todos de la Historia económica. Barcelona 1973, en concreto el capitulo dedicado a "La estructura del mercado en la economia preindustrial», págs. 459-466.

${ }^{6}$ Aguade S. y Cabañas, M. ${ }^{a}$ D., “Comercio y sociedad...", págs. 488.489.

9 Bonachia, J. A., Algunas cuestiones..., págs. 64-65.
} 
Abastecimiento urbano, mercado local y control municipal: ...

manentemente reflejada en las Actas de la época, y el control ejercido por el Concejo sobre los intercambios han dejado una constancia documental que nos permitirá saber, entre otras cosas, qué carne se come en Burgos y cuándo se come, cómo se gestiona su venta y quiénes la venden, cuánto cuesta y dónde se expende o cómo y en qué condiciones la ofrecen los comerciantes.

La finalidad primordial del Concejo, igual que en todas las partes, es garantizar un aprovisionamiento regular de vituallas y productos de primera necesidad en condiciones de ser asequibles para la comunidad urbana. La política comercial municipal responde a un objetivo prioritario que es la protección y defensa del consumidor ciudadano, en un juego contradictorio en el que abastecimiento y precios se encuentran íntimamente imbricados.

Para lograr ese objetivo se disponen medidas de indole claramente intervencionista. Por un lado, amparo de la capacidad autoabastecedora y de la producción local, en una tendencia claramente medieval que se orienta a primar la autosubsistencia y evitar una excesiva servidumbre de los recursos importados ${ }^{10}$. De otra parte, y cuando las necesidades de aprovisionamiento lo exigen debido a los déficits de la producción local, se trata de asegurar los aportes exteriores, incentivando, en tal caso, el suministro, apoyando la importación o limitando la reexportación de productos ". Se tiende, por último, a estimular la fluidez de los intercambios procurando una oferta suficiente para la demanda, evitando los acaparamientos, la especulación y las consiguientes tendencias alcistas de los precios mediante la prohibicion, freno o regulación de las actividades de la "regatonería" y, en general, a través de la adopción de todas aquellas normas de control que ayuden a alcanzar los objetivos fijados: protección de los abastecedores, prácticas monopolistas en determinadas ramas del mercado (carne, pescado,...), tasación de precios máximos de venta, controles sobre los pesos y medidas, sobre la calidad, etc...

Unos objetivos y una actuación normativa en defensa de los intereses consumidores de la comunidad urbana que, como se verá más adelante, entran en competencia y crean tensiones, de forma inevitable, con los márgenes de ganancia de los abastecedores y comerciantes y con la consecución de recursos fiscales para la Hacienda del Concejo desde el mismo instante en que la alimentación (vino, carne, harina...) se transforma,

${ }^{10}$ Bonachia, J. A., Burgos en la Edad..., págs. 297, 300, 316. Martín Cea, J. C., El mundo rural..., pág. 317. VV.AA., Bizcaya..., págs. 326 y 329. Monsalvo Antón, J. M. a , El sistema politico..., págs. 444 y ss.

'Bonachia, J. A., Burgos en la Edad..., pág. 316. VV.AA., Bizcaya..., págs. 302, 310. 
como en muchos lugares, en un soporte fundamental de las arcas municipales ${ }^{12}$.

\section{BURGOS, ¿CIUDAD DE ACARREO?}

El abastecimiento de carne en Burgos se muestra como un propósito permanente del Regimiento por prevenir la escasez. Tradicionalmente, los historiadores han considerado a la Cabeza de Castilla como una "ciudad de acarreo». Este rasgo supondria que la satisfacción de sus necesidades más perentorias no dependía sólo de sus posibilidades de autoabastecimiento, sino, principalmente, de la capacidad que tuviera para importar los productos del exterior. A su vez, este carácter explicaría la firme política del Concejo tendente, entre otras medidas, a estimular la afluencia de mantenimientos a la ciudad. Son varios los factores que se han argüido para razonar esta supeditación a los aportes foráneos: las condiciones geográficas y climáticas de la comarca burgalesa, el progreso demográfico urbano de los siglos finales de la Edad Media, el signo deficitario de la producción agropecuaria en Burgos o el desarrollo del comercio lanero como eje monopolizador de las actividades económicas ciudadanas $^{13}$. Por otro lado, la necesaria dependencia del mercado exterior para atender la demanda y necesidades alimenticias de una población en constante crecimiento se veia favorecida por el crecimiento de la riqueza urbana y las óptimas condiciones de ubicación del núcleo en una magnifica red de comunicaciones ${ }^{14}$.

17 Monsalvo, J. M. ${ }^{*}$, El sistema político..., pág. 444. Es referencia obligada para Burgos el excelente artículo de Pardos Martínez, J. A., "La renta de Alcabala Vieja, Portazgo y Barra... del Concejo de Burgos durante el siglo xv (1429-1503)", Historia de la Hacienda Española (Épocas Antigua y Medieval). Homenaje al profesor Garcia de Valdeavellano. Madrid 1982, págs. 607-689. El caso de Murcia es significativo en este orden de cosas. Véanse, como muestra, Menjot, D., Fiscalidad y sociedad. Los murcianos y el impuesto en la Baja Edad Media. Murcia 1986. Pioueras Garcia, M." Belén, Fiscalidad real y concejil en el reinado de Enrique IV: el ejemplo de Murcia (1462-1474). Murcia 1988, o Veas Arteseros, M. ${ }^{a}$ del Carmen, Fiscalidad concejil en la Murcia de fines del Medievo. Murcia 1991.

${ }^{13}$ Rıız, T. F., «La estructura económica de la zona de Burgos», en Sociedad y poder real en Castilla. Barcelona 1981, págs. 49 y ss. GonzAlez, N., Burgos. La ciudad margina! de Castilla. Burgos 1958, págs. 142- 143. Casado, H., Señores, mercaderes..., págs. 22 y ss. Bonachia, J. A., Burgos en la Edad..., págs. 311-313.

${ }^{14}$ Consúltese el clásico trabajo de Molenat, J. P., "Chemins et ponts du Nord de la Castille au temps des Rois Catholiques", Melanges de la Casa de Velazquez, t. VII, 1971, págs. 155-162. Igualmente, el capitulo dedicado por CAsauo H. a las comunicaciones en la comarca burgalesa (Señores, mercaderes..., págs. 252-260). 
Los testimonios de la época dan fe de esta doble imagen de deficitaria producción local y subordinación externa. En 1429, en la respuesta dada al rey por el Concejo a su petición de pertrechos y mantenimientos para cubrir las necesidades de sus campañas militares, se ruega al monarca que considere «que todo lo más del mantenimiento que Burgos ha mester le viene de acarreo. $Y$ por ende no puede complir tanto como las otras çibdades y villas que son abastadas de suyo de pan y de vino y de carne y las otras cosas" ${ }^{15}$ Asimismo, cuando la ciudad solicitó mercado franco al principe Alfonso, en 1465, argumentó que lo necesitaba «segund es populosa e tiene todas las cosas de acarreo" ${ }^{16}$. Por su parte, A. Navaggiero señalaba que «hasta el sol se trae a Burgos de otras partes", y añadia: «En la tierra de Burgos se cría poco vino y el trigo que se coge no es bastante, por lo que todo se trae a la ciudad en carros y mulos, pero no falta nada de lo necesario para la vida" "

Sin embargo, ¿hasta qué punto es ésta una estampa exacta de la ciudad o se trata, por el contrario, de una imagen distorsionada de la realidad? Y. Guerrero, en sus trabajos sobre la Cabeza de Castilla, ha puesto en duda este panorama, asegurando que es preciso revisar, al menos parcialmente, esa opinión compartida por toda la bibliografia local y concluyendo que "Burgos no es propiamente dicho una ciudad de "acarreo" por entero... sino que, al menos en la segunda mitad del siglo xv, se autoabastece de productos básicos para su consumo». El desarrollo de una área económica dependiente de Burgos, autosuficiente en muchos aspectos, vendria a suplir las insuficiencias productivas de la propia ciudad, de tal forma que si algunas mercancias procedian de fuera (vino, pescado,

${ }^{15}$ Por si fuera poco, el trasiego por la ciudad de gentes que acudian a la llamada de su alteza hacia más indispensable un buen abastecimiento de viandas (AMB, Actas, 1429, fol. $\left.58^{\prime}\right)$.

16 "...plega a Su Alteza de fazer merced que en la dicha çibdad aya mercado franco que sea el juebes de cada una semana de todo lo que de fuera parte se traxiere a vender e se vendiere en el dicho dia. La qual merced de semejantes mercados está otorgada a muchas çibdades y villas de sus regnos e pues esta çibdad lo ha muy más nesçesario que otro lugar alguno segund es populosa e aver todas las cosas de acarreo que lo terriá en muy grand merced" (AMB, Actas, 1465, fol. 69')

"Viaje a España del Magnifico Señor Andrés Navagero, Ed. de Alonso Gamo, José M. Valencia 1951, pág. 94. Es éste un fenómeno permanente del que tambièn darán testimonio las fuentes del siglo xvı, a diferencia de lo que el viajero veneciano señalaba, por ejemplo, para la vecina ciudad de Valladolid, aunque éste fuera un caso excepcional en el conjunto de las ciudades de la región. Por oposición a la irregularidad y dificultades para el abastecimiento que sufria Burgos, las provisiones de Valladolid eran abundantes, hasta el punto, señala Navaggiero, que era la única ciudad de Castilla en la que la presencia de la Corte no provocaba un alza inmediata de los productos alimenticios (Vid. Bennassar, B., Valladolid en el Siglo de Oro..., págs. 55-7. 
carbón...), muchas otras como el pan, la carne, las verduras, los tejidos o el calzado eran abastecidas a la ciudad por su ámbito jurisdiccional ${ }^{18}$.

El problema es ciertamente complejo, habida cuenta de las lagunas informativas que padecemos en bastantes aspectos. Pero, con independencia de lo que ocurra en otras ramas del abastecimiento ${ }^{19}$, me interesa centrar ahora el análisis en el avituallamiento de carne. Para la citada autora, la produción ganadera de Burgos y su área habria sido más que suficiente para proceder a la satisfacción de la demanda de carne urbana, siendo absolutamente escasas las ocasiones en que los ganados fueron importados desde el exterior.

A mi juicio, esta interpretación debe ser algo matizada. Ciertamente, la ciudad tuvo que recurrir en no pocas ocasiones a la importación de cabezas de ganado de fuera; e igualmente parece claro, como ha expuesto $\mathrm{H}$. Casado ${ }^{20}$, que esas reses se buscaron principalmente en los pueblos y aldeas del área periurbana, sobre todo en aquel sector, oriental y sudoriental, donde se alcanzó una cierta especialización ganadera. En la cornarca de Burgos la actividad pecuaria, dependiente de la explotación agraria, es omnipresente y se mueve en función de la urbe y del abastecimiento de su mercado. Ahora bien, no hay que olvidar que la producción campesina se destina principalmente al autoconsumo y la reproducción simple. Los excedentes ganaderos obtenidos para la comercialización son reducidos. Sólo una escasa parte de la producción termina en el mercado de Burgos. Es previsible, por lo tanto, que los rebaños campesinos fueran insuficientes para subvenir por ellos sólos las necesidades de la ciudad.

Habria que pensar mejor en medios y grandes dueños de manadas, laicos y religiosos, gentes de la ciudad y de fuera de ella, con propiedades y señorios en la comarca, que invierten en ganado para comercializar la lana y suministrar carne en la plaza burgalesa ${ }^{21}$. En 1441, los oficiales del Ayuntamiento encargaban a Juan Sánchez de Estrada que se presen-

${ }^{18}$ Guerrero, Y., Organización y gobierno..., págs. 327, 343-4, 382-3. Más matizado en algunos aspectos, en La economia de Burgos..., págs. 440 y ss.

${ }^{19}$ No me parece, por ejemplo, que Burgos fuera autosuficiente con su propia producción cerealera. Hay también aqui una extrema dependencia externa. Asi, en 1465, en el documento citado anteriormente (nota 16), resaltaba una frase: «por razón que todos los mantenimientos nesçesarios a esta çibdad son todos de fuera parte e de acarreo, e en espeçial del principal mantenimiento que es el pan....". Por otra parte, aun siendo insuficiente la producción de materiales de combustión, CASADO ALONSO H., ha demostrado que la Cabeza de Castilla se aprovisionaba en su mayor parte de estos productos, leña y carbón, en las serranias de Arlanzón y los Juarros (Señores, mercaderes..., pág. 233).

${ }^{20}$ Casado, H., Señores, mercaderes..., págs. 210 y ss.

"Kula, W. Problemas y métodos..., pág. 461. 
tara ante la Condesa de Alba, señora de Mazuelo de Muñó, y contratara con ella el abastecimiento de 500 vacas y 4.000 o 5.000 carneros. Por las mismas fechas, Bartolomé Sánchez Panero, tejedor, vecino de Burgos - un propietario que habia provisto al rey de "çiertas cabeças de ganado bacuno, toros e nouillos e vacas, las quales mandamos correr asy aqui en la dicha çibdad como fuera della a cauallo»_, entrega a la ciudad 140 vacas "que él tenia en el término de Burgos" "2. Pueden agregarse los casos de Fernando García Orense o el mercader Lope Alfonso de Burgos, el encuadernador Pero Sánchez, el escribano Gonzalo Garcia de Medina y algunos más que, de una forma u otra, abastecieron de reses al mercado cárnico de la ciudad ${ }^{23}$. No significa esto que sus aportaciones ganaderas fueran originarias de la comarca, pero el hecho de ser propietarios de tierras y ganado en las cercanias de Burgos puede abundar una interpretación en ese sentido ${ }^{24}$. En consecuencia, es necesario tener en cuenta una primera distinción en cuanto a los distribuidores de carne y el volumen de sus suministros.

Por otra parte, no cabe olvidar ciertos factores que, cuando menos, dificultarian la labor de abastecimiento comarcal de las carnicerias. Por un lado, la prohibición y condena de compra de carne en un radio de cinco leguas alrededor de Burgos, norma que se repite insistentemente a lo largo de todo el siglo, tornaria bastante laboriosa la adquisición de ganado por los carniceros locales, obligándoles a desplazarse a lugares más apartados. Además, y como ocurre en prácticamente todas las partes, los problemas ganaderos y sus insuficiencias crecieron a medida que avanzaba el siglo, cuando los prados y pastos se vieron en dificultades por el avance del proceso roturador.

En todo caso, parece obvio que el Concejo tuvo que desplazarse a buscar las reses, en no pocos momentos, a mercados bastante alejados de la ciudad. Es posible que en ocasiones no se debiera a dificultades de la producción local, sino simplemente al efecto de las discrepancias sostenidas con los carniceros burgaleses. Lo cierto es que cuando se producen problemas de desabastecimiento debido a la falta de acuerdo con

AMB, Actas, 1441 , fols. 42 y ss.

"El primero de ellos recibe seguro de la ciudad por cuanto quiere traer a ella 2.000 carneros (AMB, Actas, 1441, fol. 43'). Lope Alfonso se obliga a matar todas las vacas que pueda desde inicios de julio hasta San Miguel, y desde esta fecha en adelante 4 vacas cada semana (AMB, Actas, 1453, fol. 52'). Pedro Sánchez abastece a la ciudad con 500 corderas (Idem, ibidem, fol. 37). No sabemos las cabezas que aportó Gonzalo Garcia, pero si conocemos su demanda de liberación de la alcabala que le pedian «de los carneros que mercó por mandado de la çibdat e se vendieron en esta çibdat." (AMB, Actas, 1450, fol. 28)

${ }^{24}$ Casado, H., Señores, mercaderes..., pág. 225 
los abastecedores - «la gran necesidad de la carne» que relata alguna fuente ${ }^{25}$ - la ciudad no parece poner mayor reparo a su recurso al exterior. En 1411 la vemos buscar abasto en los lugares de la Tierra de Guipúzcoa, en Salvatierra, Segura, Mondragón y Vitoria ${ }^{26}$; la feria de Medina fue una buena suministradora de carne en varias ocasiones ${ }^{27}$; también se buscaron carniceros en Valladolid, Villalón y Dueñas ${ }^{28}$; en 1461, por fin, se despachaban varios emisarios a buscar carneros en Nueve Villas, Los Cameros y otras partes, se decidia comprar a Pedro Gómez de Porres, señor de Agoncillo, 3.000 carneros de tres años que habia ofrecido en venta, y se acordaba enviar a dos escuderos «por todas las comarcas a les facer saber cómo no tenían carneros e por merçed que les rogauan que veniesen a vender a esta çibdat sus ganados" "29. Cualquier contingencia desfavorable compelia, por lo tanto, a apelar a importaciones desde mercados y lugares distantes.

Por último, cabria valorar igualmente, como hipótesis, una relativa diferencia en la sujeción al exterior según el tipo de cabeza de ganado de que se trate, siendo posiblemente mayor respecto a los bóvidos y más reducida en lo que se refiere a la cabaña ovina, cuya dedicación a la recria para la venta de carne es muy clara en la comarca ${ }^{30}$.

La recurrencia a territorios apartados se observa algunos años más tarde -es previsible que la situación no fuera extremadamente desigual-, al contemplar los lugares de procedencia de los animales que Gregorio Guerra, obligado de las carnicerias, adquirió para abastecer la ciudad en el ejercicio de $1536-1537^{31}$. Los principales mercados proveedores de ganado vacuno fueron castellano-leoneses, siendo las ferias de Segovia y Benavente las más destacadas, al proporcionar, sólo entre ellas dos, cerca del 40 por 100 de las cabezas adquiridas. En conjunto, el 89 por 100 de los animales procede de éstos y otros mercados de fuera de la cornarca ${ }^{32}$. El resto, algo más del 10 por 100 , fue adquirido en el mercado de Burgos o en localidades próximas. La situación cambia, sin embargo, si nos referimos al ganado ovino. Aqui, fue Burgos, con mucho, el lugar más importante de compra de carneros, aunque bien es cierto

$2 b$ AMB, Actas, 1461, fol. 22.

26 AMB, Actas, 1411, fols. 3 y 18.

27 AMB, Actas, 1445, fols. 23 y 31'. Idem. Actas, 1447, fols. 99, 100 y 101

${ }^{28}$ AMB, Actas, 1447, fol. 108

${ }^{29}$ AMB, Actas, 1461 , fols. 36-36' y 44 '.

${ }^{30}$ Casado. H., Señores, mercaderes..., págs. 214-5.

31 Hernandez Esteve, E., Noticia del abastecimiento..., págs. 21, 30 y ss., y 102

32 Alba, Cervera, Medina de Rioseco, Reinosa, Saldaña, Villadiego, Montorio, Herrera, León, Melgar, El Espinar, Medellin..., son otros lugares de compra (Hernández Esteve, E., Op. cit., págs. $21-25$ y 30 ) 
que se producian algunas circunstancias especiales y las reses adquiridas no tenian por qué ser necesariamente originarias de la comarca ${ }^{33}$. Sin embargo, entre los vendedores hay poderosos mercaderes y propietarios ganaderos como Diego López Gallo. No obstante, también se trajeron cantidades importantes de mercados foráneos: Villadiego, Palenzuela, Saldaña, Puente del Arzobispo, El Espinar o Peñaranda, despuntando en sus aportaciones la feria de Medina de Rioseco y los mercados de Mérida y Badajoz.

\section{LUGARES DE VENTA: PROPIEDAD, EMPLAZAMIENTO $Y$ DENOMINACIONES}

A mediados de abril de 1260 Alfonso $X$ concedia al Concejo de Burgos todas las carnicerías de la ciudad con sus rentas, al tiempo que prohibia que nadie tuviera bancos para vender carne ni les construyera en adelante en ningún lugar, salvo los cuatro que previamente habia entregado a la Catedral, situados en la calle Tenebregosa ${ }^{34}$. La donación tiene que ver con la expansión demográfica y urbana experimentada por Burgos desde la segunda mitad del siglo xII, el consiguiente incremento cuantitativo y cualitativo de la demanda y el consumo, y es representativo de la magnitud que, a comienzos de la segunda mitad del siglo XIII, ha alcanzado esta rama de la alimentación en los intercambios locales ${ }^{35}$. Tampoco puede pasar desapercibida su significación dentro del proceso de reestructuración de la propiedad y configuración urbana que viene pro-

${ }^{33}$ Hernandez Esteve, E., Op. cit., págs. 43-44.

${ }^{34}$ "...establecemos que todas las carnecerias de Burgos poroquier que fueren que sean del Conceio e que ayan las rendas dellas libres e quietas para meterlas en pro de su Conceio. E defendemos que ninguno no aya carneceria ni bancos en la villa pora vender carne ni los faga daqui adelante en su casa ni en otro logar fueras ende los quatro bancos que Nos diemos a la Eglesia desa misma cibdat por nuestra carta plomada, que son en la mayor carneceria que es en la cal Tenebregosa sobre la Barguiella" (AMB, SH, nr. 116; 1260-IV12. Soria). Pub. GonzÁlez Diez, E., Colección Diplomática del Concejo de Burgos (884-1369). Burgos 1984, págs. 113-116. La merced que cita el monarca habia sido efectuada dos dias antes, también en Soria. Por ella concedia al cabildo de la catedral de Burgos «que ayan quatro bancos en la mayor carneceria de Burgos, que es en la cal Tenebregosa, sobre la Varguiella, e que los ayan en logar mesurado, que non sean de los meiores ni de peores. e que non ayan otros en toda la villa ni los puedan y fazer (...) que los ayan libres e quitos (por) iuro de heredat pora dar, pora uender, pora empennar, pora arrendar e pora fazer dellos cuemo de lo suyo mismo" (Pub. Pereda Lllarena, F. J., «Documentación de la Catedral de Burgos (1254-1293)", Fuentes Medievales castellano-leonesas. Burgos 1984, págs. 67-68).

${ }_{35}$ Fenómenos paralelos al desarrollo de la especialización artesanal que está teniendo lugar en la ciudad (Estepa Diez, C., Burgos en la Edad..., págs. 60-61). 
duciéndose desde la segunda mitad del siglo xll y durante toda la primera parte del xIII, en el que los establecimientos artesanales y mercantiles tienen un papel preponderante. De hecho, y en lo que se refiere a la carnicería de San Esteban, los años anteriores son testigos de una reordenación de los derechos de propiedad y de una politica agresiva de adquisición de buena parte de ellos por parte del Cabildo ${ }^{36}$. Ello hace pensar en el dominio efectivo de estos establecimientos por individuos o instituciones disociadas de la actividad de la carniceria, asi como en el establecimiento de unas relaciones de dependencia ejercidas mediante el pago de censos por los comerciantes ${ }^{37}$. Por otra parte, el privilegio se otorga en un período de transformación institucional, progresiva elitización de las estructuras politicas burgalesas, y génesis de los recursos fiscales municipales de mayor envergadura; asi mismo, es coincidente también con otra serie de sintomas que indican un marcado propósito del Concejo por regular los términos de los intercambios en la urbe ${ }^{38}$.

En relación con todas estas implicaciones, el documento de 1260 reserva al Concejo $y$, en menor medida, al Cabildo, la propiedad de los bancos de carniceria de Burgos y de las rentas por ellos generadas. De hecho, el privilegio tiende a sancionar juridicamente una situación de control del mercado, monopolio de la propiedad y extracción de renta a través de los derechos generados por los anteriores (impuestos sobre la comercialización de la carne y censos).

Sin embargo, esta situación de monopolio no se muestra tan clara en los decenios finales del siglo xIV y durante el siglo $\mathrm{xV}^{39}$. Por el contrario,

\footnotetext{
${ }^{36}$ Sobre todo en los años iniciales del siglo xIII. En 1212, Diego Bustillo cede a Pedro Miguel y su mujer la parte que tiene en una carnicería de San Esteban a cambio de una pasada de tierra y seis mrs. (1212-11-7). En enero de 1213, Juan Pérez de Vega cede al Deán y cabildo de Burgos una parte de la carniceria que posee en dicho Barrio por una pasada de tieira y 14 mrs. (1213-l-s. d.). En abril del mismo año, cuatro carniceros cederán las partes que tienen en una carniceria de San Esteban por una pasada de tierra (1213-IV-s. d.). (Pub., Garrido Garrido, J. M., "Documentación de la Catedral de Burgos (1184-1222)", Fuentes Medievales Castellano-leonesas, 14. Burgos 1983, págs. 252-3, 258-9 y 266-8 respectivamente). Vid. igualmente, Estepa Diez, C., Burgos en la Edad..., págs. 37 y ss., y 57 y ss. Sobre las pasadas de tierra, Vid. Martinez Garcia, L., "La concentración de la propiedad urbana burgalesa mediante la concesión de "pasadas de tierra" (1150-1250)", La Ciudad de Burgos. Actas del Congreso de Historia de Burgos. Madrid 1985, págs. 85-95.

37 Estepa, C., Burgos en la Edad..., págs. 77-78.

38 Ruiz, T. F., Burgos en la Edad..., págs. 128 y 163 y ss. Pardos Martinez, J. A., “La renta de Alcabala Vieja...", págs. 623-641.

${ }^{39}$ Debo observar que sólo he utilizado, dadas las características del tema, documentación concerniente, en su inmensa mayoria, al Concejo y no a otras instituciones (y básicamente, como señalé al principio del trabajo, los Libros de Actas Municipales). lo cual ocasiona previsibles lagunas, como pueden ser el desconocimiento total de la evolución de la
} 
propiedad y derechos - salvo los referidos a la fiscalidad del municipioaparecen fraccionados, en poder de diversas instituciones y particulares de la ciudad. Los datos que poseemos pueden ser expresivos. Contemplamos, por un lado, que el Concejo percibe censos colocados en diversas carnicerías de la ciudad (Vid. Cuadro I). Esa actuación como censualista implica un tipo determinado de propiedad feudal pero en absoluto excluye, como veremos, la existencia de otros posesores y beneficiarios. Además, el cobro de censos sobre los bancos de carnicerias no implica tampoco, necesariamente, propiedad del suelo donde se asientan las tablas. Durante el siglo $x v$ el Cabildo percibe rentas, a través de censos perpetuos, sobre diversos bancos ${ }^{40}$. Por otra parte, a comienzos de esa centuria, se habia entablado una agria contienda entre el Concejo y la Catedral debido, entre otros motivos, al derribo por el municipio de «çiertos bancos de tajar carne que estauan çerca de la Villa Nueva" por cuanto se encontraban en suelo y calles que eran propiedad de la ciudad. La resolución decidida por los jueces compromisarios, por razones de higiene y salubridad, y para evitar costas innecesarias, fue denegar su restitución a la Catedral y prohibirle la futura construcción de otros nuevos, a cambio de adjudicar a la Iglesia el suelo donde se encontraban dichas

CUADRO I *

\begin{tabular}{|c|c|c|c|c|c|}
\hline AÑO & C. MERCADO & C. MEDIO & ViLLANUEVA & JUDERIA & SAN PEDRO \\
\hline 1461 & $1.514 \mathrm{mrs}$. & $450 \mathrm{mrs}$. & $\begin{array}{c}140 \mathrm{mrs} . \\
(1 \mathrm{florin})\end{array}$ & & \\
\hline 1491 & & $450 \mathrm{mrs}$. & $\begin{array}{c}265 \mathrm{mrs} . \\
(1 \mathrm{florin})\end{array}$ & $\begin{array}{r}93 \mathrm{mrs} . \\
(3 \mathrm{reales})\end{array}$ & \\
\hline 1503 & $1.150 \mathrm{mrs}$ & $450 \mathrm{mrs}$. & $\begin{array}{l}265 \mathrm{mrs} . \\
(1 \mathrm{florin})\end{array}$ & & $200 \mathrm{mrs}$. \\
\hline
\end{tabular}

* Los datos de 1461 en el Libro de Actas de ese año, fs. 145' y ss. Los de 1491, en AMB $\mathrm{SH}, \mathrm{nr}$. 4470. Y los de 1503, en AMB, SH, nr. 3096. En otras listas de rentas percibidas por el Concejo, como las de 1502 (AGS, Cámara-Pueblos, leg. 4, fol. 108) y 1510 (Idem, Ibidem, leg. 4, fol. 55) no se especifican al estar englobados los censos, en un mismo bloque, con el resto de rentas de casas, tiendas y heredades.

propiedad y derechos sobre las carnicerias desde mediados del siglo $x: 1$ hasta finales del sigio xiv, o su situación real, en estos términos, durante el Cuatrocientos. Todo ello da lugar a que nos movamos en estos aspectos en el terreno de las hipótesis.

${ }^{40}$ Casado Alonso, H., La propiedad eclesiástica en la ciudad de Burgos en el siglo xv: el Cabildo catedralicio. Valladolid 1980, pág. 107. 
tablas ${ }^{41}$. Igualmente, otras personas e instituciones religiosas poseen derechos de muy diverso tipo. La abadesa del Monasterio de las Huelgas ilene titulos en la carniceria del Medio ${ }^{42}$, y en 1537 recibe de Gregorio Guerra un censo de $3.000 \mathrm{mrs}$. sobre las carnicerias arrendadas por este abastecedor ${ }^{43}$. Por su parte, $T$. López Mata apunta que el mayordomo de la fábrica de la Iglesia de S. Esteban recibia en 1473 una renta de 400 mrs., "cantidad incrementada en el año de 1515 en mil seiscientos veinticinco maravedis, de los bancos y corral y casa de la carnecería..." ${ }^{44}$. Individuos particulares también exhiben derechos de propiedad a título persona' El regidor Pedro Sánchez de Frias tiene «çiertos vancos de tajar carne en la Carneçería Mayor del Mercado..." ${ }^{45}$. En 1484, Catalina Rodríguez, viuda del licenciado Juan Alonso de Burgos, solicita que le sean respetados los justos títulis que habia heredado de su difunto marido en una banco «de la carneçeria e mercado» de Burgos, especialmente el derecho de seguir cobrando la renta anual que llevaba cada año por pesar carne en él ${ }^{46}$. Los traslados de los emplazamientos de las carnicerias que son propuestos durante el siglo XV y comienzos del XVI plantean problemas de esta indole. Asi, el que ordena doña Juana en los primeros años de esta centuria se enfrenta con la dificultad que se deriva del hecho de que existan algunas personas, iglesias o monasterios que tienen bancos en las carnicerias viejas. La solución dada por la reina consiste en dar «a los dueños de los dichos vancos, otros tales vancos en las dichas carniçerias nuevas que agora se hacen como los que tenian en las dichas carniçerías viejas (y) que el suelo donde agora están los dichos vancos en las carniçerias viejas quede libremente para esa dicha çibdad..." ${ }^{47}$.

El cambio de ubicación de la Carniceria del Medio pone de manifiesto la compartimentación de derechos y titulos señoriales que existe en relación con estos establecimientos. Uno de los elementos de la discusión, en las conversaciones entabladas para su traslado entre el Ayuntamiento y Sancho Diaz de Almotar, era el «tributo de çiertos maravedís» que la ciudad poseia en ella. El compromiso inicial del mercader, en 1429, consistía en que los censos colocados en la carnicería antigua se mantuvieran en el nuevo edificio que él se proponía construir, al tiempo que el suelo continuaba bajo su propiedad. En el transcurso del debate, algunos

\footnotetext{
${ }^{41}$ AMB, SH, nr. 1155 (1406, diversas fechas).

4. AMB, Actas, 1430, fol. 105.

${ }^{43}$ Hernández Esteve, E., Noticia del abastecimiento..., pág. 110.

${ }^{44}$ Lopez Mata, T., El Barrio e Iglesia de San Esteban. Burgos 1946, pág. 28.

${ }^{45}$ AMB, SH, nr. 808 (1434-XII-15, Madrid).

${ }^{46}$ AGS, RGS, II-84, fol. 35 (1484-\|-20, Agreda).

47 AMB, SH, nr. 2389 (Valladolid, 1513-X-21).
} 
Abastecimiento urbano, mercado local y control municipal: ...

meses más tarde, ya en 1430, surgieron dos cuestiones centrales: en primer lugar, la petición que realizaron ciertos oficiales para que Sancho Diaz otorgara un censo superior al que la ciudad poseia con antelación, en contrapartida por la merced que se le hacia; $y$, en segundo término, que fueran investigados los posibles perjuicios que se podian ocasionar con el traslado a quienes tuvieran títulos en las instalaciones, como el carnicero Sancho Fernández o la abadesa de las Huelgas. Cuando a finales de 1431 se acordó que la construcción en el nuevo emplazamiento se llevara definitivamente a cabo, se hizo bajo algunas condiciones. Una de ellas fue que Sancho llegara a un acuerdo con los herederos "que tienen bancos en la dicha carniçeria"; otra consistió en dar seguro a la ciudad del censo que poseia, que se fijaba ahora en $225 \mathrm{mrs}$. de moneda vieja (los $450 \mathrm{mrs}$. que aparecen en algunas cuentas en años posteriores. Cuadro 1) ${ }^{48}$. Por último, los dos bancos de vaca y carnero y el peso de trigo y harina otorgados a los vecinos y moradores del Barrio de San Pedro en su carnicería, por un censo de $900 \mathrm{mrs}$. anuales, fueron cedidos con la restricción de que los censatarios no pudieran vender las carnicerias sin conocimiento y licencia previos de su concejo ${ }^{49}$.

Como se puede observar, hay diversos censualistas y propietarios de tablas y suelos de las carnicerias (Concejo, Cabildo, Huelgas, Iglesia de San Esteban, particulares...) que, a través de los censos y alquileres cobrados a los abastecedores y explotadores de los bancos, participan indirectamente en los beneficios originados por el comercio de la carne. Las condiciones decretadas en 1436 para el abastecimiento del producto son esclarecedoras en este orden de cosas: el arrendador y proveedor de las carnicerias se compromete a pagar los censos de los bancos a la ciudad y abonar una cantidad razonable a los dueños de las tablas ${ }^{50}$. La trama de derechos de propiedad que recaen sobre éstas puede ser bas-

${ }^{48}$ AMB, Actas, 1429, fol. 42'; Idem de 1430, fol. 105; Idem de 1431, fols. 21-21', 30' y 31'

${ }^{49}$ AMB, Actas, 1484, fols. 5 ' y ss. (También, en AGS, RGS, X-86, fol. 1; 1486-X-3, Santiago, en confirmación de Fernando e Isabel). En el contrato firmado por ambas partes se estipula que durante el primer año fueran abonados a los arrendadores de la barra $700 \mathrm{mrs}$. Como compensación por el trigo que fuera llevado al peso tomado a censo, ya que en las condiciones de dicha renta entraban los pesos de las harinas-y los $200 \mathrm{mrs}$. restantes al mayordomo de la ciudad. Durante los años siguientes deberían pagarse íntegramente los 900 mrs. No debió suceder asi, por cuanto se puede comprobar que la cantidad asentada en las cuentas de 1503 era sólo de 200 mrs (Cuadro 1).

so Condiciones de la carne de 1436: "Otrosy, que la dicha cibdad sea obligada de dar las carnesçerias acostunbradas desenbargadas donde el arrendador faga vender las dichas carnes donde se suelen vender fasta aquí, pagándolo el que lo asy arrendare los ençiensos de la dicha çibdad de los dichos vancos".- "Otrosy, al dueño de los tales vancos quel dicho arrendador que le de e pague por cada uno de los dichos vancos el preçio razonable segund suelen pagar en los años pasados». (AMB, Actas, 1436, fol. 15'). 
tante compleja, pero no es menos claro que no se encuentran monopolizados en sentido estricto en manos de una sola persona jurídica, existiendo por el contrario una cierta tragmentación ${ }^{51}$.

¿Existe alguna evolución hacia un mayor control de las carnicerias por el Regimiento? El pleito de 1406 con el Cabildo pareceria apuntar en ese orden de cosas. Pero no hay otros datos que sugieran una orientación muy activa en ese sentido. Parece bastante seguro que el Concejo era ya el mayor señor de derechos sobre las instalaciones de la ciudad. El episodio del censo tomado en 1484 por los vecinos de San Pedro implica una muy amplia capacidad de posesión del concejo sobre las carnicerias de ese barrio, y es muy posible que asi ocurriera con la mayor parte de las tablas urbanas. Por lo demás, los ingresos que obtiene en forma de censo son relativamente sustanciosos, al menos por comparación con los que recaudan otras entidades ciudadanas o los que perciben los Concejos de otras ciudades castellanas ${ }^{52}$.

Pero si no hay ur monopolio absoluto del Concejo sobre la propiedad de las carnicerias, si existe, por el contrario, un control pleno de todo el proceso de abastecimiento ${ }^{53}$. Las posibilidades de consumo de carne en la ciudad dependen fundamentalmente de un correcto funcionamiento de los cauces de aprovisionamiento. Durante todo el siglo xv se puede contemplar, por lo tanto, una extrema vigilancia del Concejo sobre este sector de la alimentación y una manifiesta politica intervencionista que afecta tanto a la circulación como a la venta.

Uno de los signos más sobresalientes de ese notable intervencionismo municipal se encuentra en la fijación de los lugares de venta de los productos. Los carniceros, al igual que los comerciantes de otras ramas del sector alimenticio (panaderos, fruteros, pescaderos, taberneros...), deben efectuar sus ventas en lugares expresamente asignados por la autoridad ciudadana, localizados en diversos puntos del espacio burgalés. El Concejo actúa como ente regulador de la ubicación urbana de los establecimientos que comercian con la carne. Dicha regulación le permite garantizar un mejor control sobre las mercancias y las ventas y facilita la labor

Vid., a este respecto, los casos de Murcia y Cuenca (Op. cit.)

"CASAdo, H., afirma que las rentas recogidas por el Cabildo son muy escasas (La propiedad eclesiástica..., pág. 107). En 1497, las carnicerias de Cuenca rentaban 1.355 mrs., cifra algo inferior a los 2.065 mrs. recaudados por el Concejo burgalés en 1503, y superior a los 808 mrs. que se anotan en las cuentas de 1491, aunque aqui no se han contabilizado los producidos por las Carnicerias del Mercado. ( Aguade, S. y Cabañas, M. D. "Comercio y sociedad...", pág. 506).

53 Lo que Marin Garcia M. a Ángeles, denomina - para el caso de Murcia, bastante más evidente- una dicotomia entre la propiedad de los inmuebles y el abastecimiento de carne ( «Las carnicerias y el abastecimiento...”, págs. 55 y 59). 
de vigilancia de los fieles en el cumplimiento de la normativa municipal (umbrales de precios, utilización de pesos adecuados, calidad de los productos, etc.). En segundo lugar, simplifica las vias de percepción por parte de arrendadores y recaudadores de los impuestos que recaen sobre las transacciones ${ }^{54}$. Por corisiguiente, sólo en los lugares señalados por el Concejo pueden realizarse las ventas ${ }^{55}$.

Las carnicerias burgalesas estaban repartidas por todo el casco urbano. La más importante era la "Carnicería del Mercado" o "Carnicería Mayor», emplazada cerca del Mercado, junto al rio Vena ${ }^{56}$. La "Carnicería de Enmedio" se localizaba, en un principio, en la calle Tebregosa ${ }^{57}$. Durante el segundo cuarto del siglo $x v$ se produjo su traslado a un lugar cercano, en la ladera del Castillo, en los aledaños de la Iglesia de San Román. El suelo para las nuevas instalaciones fue ofrecido al Concejo por el mercader Sancho Díaz de Almotar en junio de 1429, pero sólo dos años y medio más tarde se dió el definitivo permiso municipal para mudar la carniceria. El traslado se consumó en 1441, provocando de inmediato las quejas de los vecinos de San Román. No en vano las razones que unos años antes habían convencido a los oficiales para efectuar el cambio de ubicación habian sido, además de la mayor amplitud de los nuevos es-

${ }^{54}$ En 1495, se dan noticias de los guardas de los siseros (AMB, Actas, 1495, fol. 145'). En 1496, se otorga licencia a Diego de Villanueva, arrendador de la sisa de la carne, para poner guardas que puedan entrar en las carnicerias y controlar las ventas, al igual que lo hacen los arrendadores de las alcabalas de sus altezas (Idem, Actas, 1496, fol. 61'). En (484, se sugiere que los arrendadores y cogedores de la alcabala pueden escribir mejor la carne que se pesa y vende en la carniceria y asi recibir y recaudar el alcabala de ello (AGS, RGS, I -1484 , fol. 35; 1484-II-20, Agreda). En ocasiones, es el mismo abastecedor quien se hace cargo de las rentas de la carne: "Otrosy, con tal condiçión quel arrendador en quien se rematare esta dicha renta que sea tenudo e obligado de tomar los derechos que pertenesçen a la çibdad en las carnes muertas en los años de treynta e siete e treynta e ocho e treynta e nueue, en quantía de setenta e çinco mill mrs. cada año e que faga recabdo al mayordomo en cada vno de los tres años, e dé fiadores a cada mayordomo de los dichos tres años". (AMB, Actas, 1436, fols. 16).

${ }_{55}$ El 29-VIII-1476, junto a otros preceptos sobre la venta de carne, se prohíbe que nadie "pueda vender ningunos carneros ni vacas dentro en las botycas ni en otras partes de la carneçeria salvo en los logares e vancos públicos porque no puedan encobrir ni puedan dezir que an dado la carne que están obligados..." (AMB, Actas, 1476, fol. 60'). Por su parte, los carniceros de la Corte, cuando ésta se encuentra en la ciudad. pueden vender carne en el rastro a cualquier persona, pero siempre bajo las condiciones impuestas por el municipio (AMB, Actas, 1463, fol. 75; AGS, Cámara-Pueblos, leg. 4, fol. 116; 1476-1-20, inserto en conf. de doña Juana de 1506-1-24).

:6 “...en las Carneçerías Mayores, que son çerca del Mercado...” (AMB, Actas, 1458, fol. 11); "...tiene ciertos vancos de cortar carne en la carneçeria mayor desa dicha çibdad, detrás de las quales corre un rio que se llama río Vena..." (AMB, SH, nr. 808).

"B «Bien sabedes que la çibdad tiene la carneçeria de Medio en la cal Tenebregosa..." (AMB, Actas, 1429, fol. 42'). A mediados del siglo xill era la mayor de la ciudad según expresa el privilegio del Rey Sabio anteriormente citado (Vid. n. 34). 
tablecimientos, motivos de higiene (insalubridad y molestias ocasionadas a la vecindad por sus malos olores, sobre todo durante el verano), y prestancia urbana (por encontrarse la carniceria antigua en una «calle de las honrradas de Burgos», por donde pasaba el Rey siempre que llegaba a la ciudad, y no ser adecuada, por tanto, al «bien parecer» de ella) ${ }^{58}$.

Las anteriores no son las únicas carnicerias burgalesas, aunque sí las más sobresalientes. Hay otras tres en San Esteban, San Martín y el arrabal de San Pedro. Esta es la única que se ubica extramuros de la ciudad, junto al puente de los Anadinos. Como se ha visto, dos de sus bancos, uno de vaca y otro de carnero, fueron censados por el Concejo a los vecinos y moradores del Barrio en 1484, para que fueran abastecidos por ellos mismos ${ }^{59}$. La documentación también menciona la existencia de una carniceria de la Villa Nueva o "çerca de la Villa Nueva" ${ }^{60}$. Posiblemente se confunda o haya sido absorbida por la de San Martín. Aunque a comienzos del siglo xv/ el Concejo sigue percibiendo un censo bajo ese concepto (Vid. Cuadro I), de hecho, en la documentación de finales del último cuarto del $x v$, no aparece mencionada entre las carnicerias que deben ser provistas y cuando se habla de "todas las carneçerias de esta çiudad" sólo se enumeran las cinco anteriores ${ }^{61}$. Finalmente, es muy dificil evaluar, dada la penuria de la información de que disponemos, la presencia y particularidades de las carnicerias de las minorias étnico-religiosas, aunque es obvio que sobre ellas también recaia el control concejil ${ }^{62}$.

${ }^{58}$ Toda la secuencia del traslado puede verse en AMB, Actas, 1429, fol. 42'; 1430 , fol. 102 ' a $105 ; 1431$, fols. $21-21$ 'a 31 '; 1432 , fol. 61 y 1441 , fols. 29 ' a 31

s9 Vid. n. 49.

${ }^{60}$ AMB. Actas, 1432, fol. 82. Según GonzÁlez Diez, Emiliano, el nombre de Villa Nueva o Puebla Nueva parece referirse al espacio comprendido entre Santa Maria la Blanca y la Calle de ias Armas (El Concejo burgalés (884-1369). Marco histórico-institucional. Burgos 1983, pág. 272). Para Lopez MATA, T., cel núcleo principal de la juderia parecia centrarse, a principios del siglo $\times V$, en el barrio conocido con el nombre de Villa Nueva, al sur de la Calle de las Armas...» (“Moreria y juderia», BRAH, t. 129, 1951, págs. 340 ss.).

${ }^{61}$ Compromiso para abastecer los bancos de las carnecerias del Mercado, y los de las Carnecerias de Medio, San Esteban, San Martin y San Pedro (AMB, Actas, 1484, fol. 26). Compromiso "de dar avasto en las carneçerias desta çibdad todas que son... en las carneçerías mayores..., en la carneçeria de medio... en la carneçeria de Sant Esteban.... en la carneçeria de Sant Martín..., e en las carneçerias de Sant Pedro..." (AMB, Actas, 1497, fol. 95).

${ }^{62}$ En el contrato de abastecimiento que suscribe en 1436, Juan Sánchez de Estrada se obliga a proveer de carnero y vaca las carnicerias de los judios y moros de la ciudad (AMB, Actas, 1436, fol. 26'). En 1493, los parroquianos y clérigos de Santa María la Blanca y Santa María de Vieja Rúa denuncian los agravios que hacen los moros con su carniceria ya que muy cerca de ella "pasan el Cuerpo de Dios y las cruces" (AMB, Actas, 1493, fol. 68). Sobre ellas también caen los impuestos y los derechos de los arrendadores (Idem, Actas, 1398, fol. $40 ;$ y 1436, fols. 14' y ss.). Ni CANTERA, Francisco, "La judería de Burgos", SEFARAD, 1952, págs. 59-104, ni LOPEZ MATA, T., Op. cit., ofrecen datos sobre este particular. 
El intervencionismo concejil en la regulación de los puntos de venta se refleja lógicamente en cualquier reforma que se realice, ya sea en los traslados de las carnicerias, en eventuales modificaciones de la ubicación de los bancos ${ }^{63}$, o en la edificación de otras instalaciones adyacentes. En la dispersión de los establecimientos por el recinto ciudadano y sus cambios de emplazamiento hay un propósito de embellecer la fisonomia urbana y mejorar las condiciones higiénicas de la comunidad, intención acorde con el momento de notable impulso económico y demográfico que vive la ciudad y que la lleva a experimentar una importante remodelación de su estructura urbanistica. Se ha comprobado con el traslado de las Carnicerías del Medio: del mismo modo, será la razón primordial argüida para efectuar la nueva mudanza que tiene lugar en los inicios del siglo $X V I^{64}$.

Pero ese control también tiene que ver con un permanente esfuerzo por dominar el espacio ciudadano, su utilización económica y las actividades comerciales en él desarrolladas, sin que, por otra parte, se produzca merma alguna en sus derechos ${ }^{65}$. Una idea central en el traslado propuesto por Sancho Diaz de Almotar en 1429 era mantener y, en todo caso, aumentar los censos que la ciudad tenia en la Carnicería. Cuando en 1488 los judíos solicitaron que fuera cambiada la carniceria junto a la cerca - ila de la juderia?, ¿la de San Martin?--, lo pidieron sin menoscabo para el censo de la ciudad ${ }^{60}$. En 1430 , el regidor Pedro Sánchez de Frías solicitó licencia para edificar unas casas junto al rio Vena, en las traseras de las carnicerias, sobre unos solares y ejidos del Concejo, en las cuales pudiera tener la carne y el ganado que matase y se cortara en los tableros de los que él era propietario. Se le concedió el permiso porque el lugar estaba despoblado, no rendia nada a la ciudad y, según muchos testigos, seria más provechoso para el municipio hacer un edificio que a nadie perjudicaba antes que tener un lugar estéril ${ }^{67}$.

\footnotetext{
${ }_{63}$ Los oficiales impiden que los dueños de los bancos y los carniceros saquen aquéllos de los limites en que solían estar (AMB, Actas, 1489, fol. 240)

${ }_{64}$ «...que mudasedes las carniçerias de esa dicha çibdad de donde agora están porque están en lugar muy perjudiçial a la salud de todos los vezinos de esa dicha çibdad y espeçialmente de los vezinos de las dichas calles - Huerto del Rey y Salineria - e porque estaua ocupado con ellas el mejor lugar y paso de toda esa dicha çibdad, por donde contynuamente pasan todas las personas que en ella están y porque a cabsa de los malos olores que salen de las dichas carniçerias se enponçonan todos los que por alli pasan..... (AMB. $\mathrm{SH}$, nr 3030; 1512-XII-27, Burgos). También en AMB, SH, nr. 2388 (1513-VIII-20, Valladolid) y 2389 (1513-X-21-Valladolid). Vid. IBAÑEZ, A. C., Burgos y los burgaleses en el siglo xvi. Burgos 1990, págs. 196-7.

is Aguade S. y Cabañas, M. ${ }^{a}$ D., Comercio y sociedad..., págs. 504-505

${ }^{66}$ AMB, Actas, 1488, fol. 184.

6r AMB, Actas, 1430, fol. 97'; AMB, SH, nr. 808 (1434-X|I-15, Madrid).
} 
El número de tablas de las carnicerias es variable y refleja el volumen de despacho de cada establecimiento. Sin lugar a dudas, la que tiene mayor número de bancos es la Carniceria Mayor, a la que hemos contabilizado, en 1436, hasta 19 tablas, 10 de carnero y nueve de vaca ${ }^{68}$. La del Medio debia tener un máximo de 10 bancos según las condiciones de traslado impuestas en 1431 a Sancho Diaz ${ }^{69}$. A medida que avanza el siglo, se observa en los contratos de obligación de los abastecedores una diseminación de los despachos por las cinco carnicerias de la ciudad y una paralela disminución de los bancos que debian ser abastecidos en las dos citadas. Así, en 1497, y teniendo en cuenta que los carniceros se obligan a proveer todas las carnicerias, se especifican en el contrato 12 bancos en el Mercado y dos en cada una de las restantes ${ }^{70}$. En conjunto, el total de tablas que son abastecidas oscila en el último cuarto de siglo entre 20 y $24^{71}$. No puede olvidarse, además, que en Burgos los únicos que son regulados son los bancos de vaca y carnero; por el contrario, no se establecen nunca las tablas de las otras carnes o se mencionan de forma indeterminada ${ }^{72}$.

\section{LA REGULACIÓN DE LA CIRCULACIÓN}

Ya se ha señalado que el objetivo prioritario de los Concejos es facilitar un buen abastecimiento de la población intramuros a un precio razonable. El intervencionismo municipal en la comercialización de alimentos afecta también a la circulación de las mercancias. De tal modo, se habilitan medidas de control de las importaciones y exportaciones, tales como vedar la salida de provisiones, retener las vituallas que transitan por la ciudad o intervenir en el comercio de los productos de su entorno rural.

La prohibición de saca tiene una finalidad obvia: proteger la producción propia para evitar posibles desabastecimientos y carestias con su

${ }^{68}$ AMB, Actas, 1436, fol. 14' y ss

69 AMB, Actas, 1431, fol. 31'.

70 AMB Actas, 1497, fol. 95.

7 Frente al dato anterior, en 1496, y debido a la falta de acuerdo con los carniceros, las vecindades de la ciudad se comprometieron a abastecer las carnicerias por ellas mismas y se repartieron, sin especificar dónde, un total de 24 bancos, 13 de carnero y 11 de vaca (AMB, Actas, 1496, fol. 66). (Vid. Cuadro V).

"Del estilo "quantos bancos quisiere de las otras carnes" (AMB, Actas, 1436, fols. 14" y ss.) 
consecuente presión inflacionista sobre los precios. Es ésta una norma que veremos aplicar en Burgos con bastante asiduidad en otros productos, como el vino o el pan, pero no así en la carne ${ }^{73}$. La razón de este silencio se debe, probablemente, a su mayor dependencia del exterior en este sector y la propia dificultad de abastecimiento por los carniceros, que evitaría la reexportación. Esa supeditación y la debilidad de los pastos concejiles explican igualmente alguna medida aislada que impide la estancia en Burgos de ganados foráneos no destinados al mantenimiento local, penándose la infracción con su destino al abastecimiento propio ${ }^{14}$.

Mucho más precisa y reiterativa es la prohibición de comprar carnes en un radio de cinco leguas alrededor de Burgos. En 1388, el monarca extendia a la ciudad el decreto que habia impuesto durante su estancia en las Cortes de Briviesca impidiendo que los regatones compraran cualquier tipo de viandas en un entorno de la Corte de cinco leguas ${ }^{75}$. Durante el siglo $x v$ esta ley también se hace extensiva, de forma explicita, a los carniceros y a la compra de carries en Burgos y en un radio de la misma magnitud. En diversas ocasiones se veda la compra de cabritos, corderos, terneras, carneros, gallinas, pollos, pollas, anserones, «ni otra carne alguna" en este espacio. Unas veces, la prohibición se refiere a un tipo determinado de ganado; otras, atañe a todas las carnes en general ${ }^{76}$. En algunos momentos, pocos, la restricción se eleva a un radio de 10 ó 15 leguas $^{77}$.

${ }^{3}$ Sólo poseemos alguna noticia aislada como la prohibición a los carniceros de saca de sebo para su venta en el exterior (AMB, Actas, 1458, fol. 107).

${ }_{74}$ "Ordenaron que qual quier que traxiere ganado a la çibdat o a sus términos, que no fuere para mantenimiento de la dicha çibdat, que no se pueda detener ende más de un dia e sy más se detouiere, que dende ay adelante que lo pueda tomar la dicha çibdat para mantenimiento e prouisión della al preçio que entendiere la dicha çibdat que sea razonable». (AMB, Actas, 1445, fol. 32).

is "...bien sabéis que en las Cortes de Brivisca ordenamos que los regatones no comprasen viandas algunas en la Corte y en cinco leguas a derredor para venderlo a regateria, porque la nuestra Corte fuese abastada a menores precios... es nuestra merced que dicho ordenamiento se use en Burgos y hasta las cinco leguas en derredor... tan bien en el tiempo que la Corte esté alli como cuando no esté alli..." (AMB, Actas, 1388, fol. 16. Carta de 1388II-20). El ordenamiento del rey se vuelve a repetir en 1391 (Idem, 1391, fol. 20). Esta medida también se observa en otros lugares (Vid., por ejemplo, de Santos Canalejo, E. C., La Historia Medieval de Plasencia..., pág. 449, referida aqui a la caza; o Bennassar, B., Valladolid en el Siglo de oro..., pág. 62).

"Que ningún carniçero ni regatón sea osado de salir andar fuera de la çibdad en término de çinco leguas, ni en la çibdad, otrosy cabritos, ni corderos, ni carneros, gallinas, pollos, pollas ni anserones, ni otra carne alguna so pena..." (AMB, Actas, 1411, fol. 18). Que los carniceros no compren terneras en la ciudad ni dentro de cinco leguas (Idem, 1429, fol. 43). Notificación a los carniceros de que nadie compre carnes en Burgos ni en cinco leguas alrededor (Idem, 1480, fol. 87). Las ordenanzas concejiles en este sentido son constantes.

$"$ Que nadie compre ternera fuera de Burgos, diez leguas enderredor (AMB. Actas, 1471, 
Esta limitación debe tener una lectura en un doble sentido. En principio, el objetivo perseguido aparece transparente desde los primeros instantes. Lo señala el rey en su carta de 1388: adquirir suministros a menores precios ${ }^{78}$. Se trata de evitar el acaparamiento, la especulación y el encarecimiento de los productos por la presencia de la reventa y los regatones. No es raro, pues, que, de forma perseverante, se impida a los carniceros la adquisición de carnes con objeto de "tornarlo a revender en Burgos»; o que, en todo caso, se les imponga la obligación de despachar las mercancías asi compradas según el precio de coste ${ }^{79}$. Por consiguiente, la medida tiene un propósito inicial que emparenta con el que se propone la veda de saca de productos de las ciudades: evitar el alza de precios. Pero, como contrapartida, este precepto obstaculiza el abastecimiento de los carniceros en el alfoz y en la comarca de Burgos y se relaciona con la necesidad de desplazarse a lugares más distantes para proveerse de animales de todo tipo ${ }^{80}$. La intensidad con que se reiteran tanto las disposiciones con este fin como las penas en las que incurren los carniceros es una buena muestra de esa dificultad y de la reincidencia en la transgresión de la norma. Por eso, tampoco faltan, en momentos de más imperiosa necesidad y como recurso para evitar una posible esca-

fol. $\left.30^{\circ}\right)$. Penas a ciertos carniceros que han comprado carneros "dentro de las quince leguas" (Idem, 1483, fol. 28).

${ }^{78} \mathrm{Vid}$. n. 75. La eliminación de intermediarios y acciones especulativas no beneficia al productor sino al consumidor de las aglomeraciones urbanas. Es otra muestra más de la situación de privilegio, reforzada por el control municipal del mercado, que presenta la ciudad frente al entorno rural (KuLA, W., Problemas y métodos..., pág. 463)

${ }^{79}$ Nadie compre cabrito dentro de cinco leguas de Burgos "para revender en Burgos" (AMB, Actas, 1465, fol. 37). No se pueden traer terneras compradas en un radio de 10 leguas "para las revender en Burgos, salvo el que la traxiere de parte de ella a los que la quisieren al precio que le costó, sobre juramento que haga de ellom; en caso contrario, perderá la ternera (Idem, 1471, fol. 30'). Queja contra los carniceros que actúan contra las ordenanzas de Burgos, comprando carnes dentro de las cinco leguas y tornándolas a revender; si alguien ha actuado de esta forma, que pierda las carnes o las dé a los vecinos de la ciudad a) precio que le costaron (/dem, 1480, fol. 90). "Ordenaron e mandaron que ninguna persona que sea, para lo tornar a rebender, no compre en esta çibdad ni çinco leguas en derredor, carneros ni bueyes, ni vacas ni cabrones, ni cabritos, ni ovejas, ni corderos, ni conejos, ni perdiçes, ni otra caça alguna, ni quesos, ni gallinas, ni capones, ni pollos, ni otras aves algunas, so pena...». Que el regatón que traiga tales cosas a la ciudad presente testimonio de cómo lo compró fuera de ese espacio; de lo contrario, pierda los mantenimientos (Idem. 1497, fol. 114).

${ }^{80}$ No podemos olvidar que el Concejo de Burgos contaba con unos términos y un alfoz de reducida extensión. En un documento de 1559 se aseguraba que esta ciudad atiene muy corta jurisdicçión y de muy pocos lugares, pequeños y pobres, y la jurisdicçión que tiene por lo más largo se estiende dos leguas y aún por algunas partes no las tiene..." (BONACHIA Hernando, J. A., El señorio de Burgos durante la Baja Edad Media (1255-1508). Valladolid 1988 , págs. 21 y ss.). 
sez, las franquicias temporales de la ley ${ }^{81}$. En definitiva, esta norma, que regula las importaciones del más inmediato entorno, introduce elementos de contradicción en la politica intervencionista del Concejo: frente a la priorización del principio que lleva a preveer y limitar en lo posible cualquier contingencia que provoque una presión inflacionista, se debilita el que aspira a procurar un abastecimiento fácil, regular y estable del mercado local.

Pero, en segundo lugar, esta limitación también puede interpretarse en el sentido de provocar la atracción hacia el núcleo urbano de la producción de los alrededores. Los intercambios tienden a concentrarse en el más importante mercado de la comarca, tanto para los ciudadanos como para los campesinos. Como ha estudiado muy bien $\mathrm{H}$. Casado ${ }^{82}$, toda la circulación de bienes se dirige hacia las orillas del Arlanzón. Las instituciones mercantiles burgalesas, feria y mercado, asi como la mayor demanda urbana, unos precios más altos y una adecuada red de comunicaciones, ejercen un efecto centralizador en la comercialización de los excedentes campesinos, aminorando a su vez la actividad mercantil en otros lugares de la región. Pero a la atracción que ejerce el mercado urbano, se une también una determinada política concejil, que imposibilita comprar carnes en los alrededores o que prohibe salir de la ciudad a adquirir los productos y vituallas antes de que lleguen a su lugar reglamentado de venta ${ }^{83}$. Es dificil conocer el nivel de fluidez de intercambios existente entre la ciudad y las aldeas circundantes. Con toda probabilidad, el campesino de los entornos acudia al mercado burgalés a comprar muchas provisiones necesarias para su mantenimiento; pero, además, no tendrá más remedio que acercarse a la ciudad si quiere vender sus excedentes, sobre todo si no puede utilizar intermediarios o la actividad de éstos encuentra muchas dificultades. En definitiva, se promociona el abastecimiento directo y se penaliza la reventa.

8) El 20 de febrero de 1481 los carniceros alegan que no podrian abastecer las carnicerias durante el poco tiempo que quedaba hasta Carnestolendas si tuvieran que ir a buscar las carnes "fuera de los limites que la ordenanza de la ciudad dispone". Ante dicha realidad, la ciudad les dispensa de la norma, pero sólo durante este periodo de tiempo y sin que tal medida signifique la derogación de la Ordenanza (AMB, Actas, 1481, fol. 16). En enero de 1488 se da una nueva licencia a los carniceros para que «hasta Carnestolendas puedan comprar ganados en la Tierra» (/dem, 1488, fol. 138).

${ }^{82}$ Casado Alonso, H., Señores, mercaderes..., págs. 262-265.

${ }^{83}$ Que nadie compre fuera de Burgos ni de sus puertas cabritos, corderos, gallinas, capones u otras aves, conejos, liebres ni caza de lo que se viniere a vender a la ciudad (AMB, Actas, 1476, fol. 15). A Pedro de Almendras, carnicero, se le embargan cuatro de los puercos que tenía, por cuanto les adquirió fuera de Burgos cuando venian al mercado a venderse (ldem, 1478, fol. 6) 


\section{EL CONTROL SOBRE LA VENTA}

Una vez que los productos han llegado a la ciudad, el control municipal es aún más intenso. Toda la actividad mercantil —desde la fijación de los lugares de venta, como ya se ha visto, hasta el establecimiento de los precios, pasando por la utilización de pesos y medidas, la inspección de la calidad de los productos o los deberes y derechos de los comerciantes-, todo, en definitiva, escapa del control de los particulares y es mediatizado por la politica intervencionista del Concejo.

\section{A) El sistema de obligados}

Como sucede en otras ciudades medievales y como también seguirá ocurriendo durante el siglo xVI, Burgos recurrirá para el suministro y comercio de la carne al sistema de "obligados»: la gestión de venta se deja en manos de particulares que se obligan, mediante contrato, a abastecer ciertos productos al consumidor, a unos precios de venta determinados, con unas condiciones previamente estipuladas y durante un periodo de tiempo también establecido pero variable, con la contrapartida de la exclusividad.

Esta es la primera caracteristica del sistema: su adjudicación con "carácter monopolista”. La eliminación de la competencia aparece como contraprestación otorgada por el Concejo al compromiso de abastecimiento y de contención de precios que supone aceptar unas tasas establecidas por contrato ${ }^{84}$. El sacrificio y venta de carne constituye un monopolio garantizado por la autoridad municipal, tanto a través de las disposiciones contractuales, como en otras normas concejiles de carácter complementario - por ejemplo, mediante la utilización preferente, y a veces exclusiva, de los pastos municipales-. La condición se repite con frecuencia y de forma muy significativa en los convenios suscritos por los obligados, con fórmulas diferentes entre unos y otros, pero siempre con el mismo espiritu anticompetitivo ${ }^{85}$.

84 Aguade, S. y Cabañas, M. ${ }^{a}$ D., "Comercio y sociedad." págs. 509 y 516.

3s Con compromiso que den ellos la carne "e no otra persona alguna" (AMB, Actas, 1433, fol. 148'). "Otrosy, que ninguna ni algunas personas, de qual quier estado o condiçión que sean, que no sean osados de vender ni matar carne ninguna para lo vender en la dicha çibdad, ni en sus arrauales ni términos, en los dichos quatro años, ni en alguno de ellos, so pena que pague cada una vegada que pueda paresçer o aberiguar mill mrs. e demás que pierda la carne, e esta pena que sea para el que esta renta arrendare, saluo aquel o aquellos quel arrendador mandare e para sy posiere que lo mate o venda." (AMB, Actas, 
Hay que observar, en segundo lugar, que el abastecimiento urbano por el procedimiento de obligados concierne únicamente al comercio diario. Asi figura en bastantes contratos, de forma explícita en unos casos, o implicitamente en otros a través de la fijación de penas por incumplimiento de las obligaciones ${ }^{86}$. No afecta, sin embargo, al mercado franco del sábado, del que está desvinculado y con el que se procura evitar interferencias: hasta el extremo de que inmediatamente después de su concesión por los Reyes Católicos en 1475, se tiende a prohibir o reducir la venta de carne durante ese dia, probablemente con la intención de eliminar competencia a los aportes foráneos y promocionar su atracción ${ }^{87}$.

\section{B) Los procedimientos del abasto de carne y su evolución}

Durante los dos últimos decenios del siglo XIV, las Actas del Concejo se limitan a presentarnos una actividad municipal reducida a establecer los precios de la carne y exigir un buen abastecimiento. El primer cuarto del siglo $\mathrm{xV}$, hasta 1427, constituye un periodo mejor conocido, durante el cual son los carniceros de Burgos quienes se comprometen a avituallar la ciudad, aceptando una condiciones previas establecidas por el Concejo e iguales para todos. La obligación se realiza tras llegar a un convenio

1436, fol. 15'. Condiciones de abasto de 1436); «..con tal condiçión que ninguno no sea osado de oy en adelante de vender ninguna carne sin nuestra licencia e espeçial mandado... (AMB, Actas, 1461, fol. 83) etc, etc. En 1463, los obligados se quejan ante el Concejo que aigunos, no siendo carniceros de la Corte, vendian vaca y carnero en el Rastro. Los oficiales ordenan a los infractores que, en adelante, no pesen más carne a rastro (/dem, Actas, 1463, fol. 75). La limitación de venta de la carne a favor de quienes la han contratado con el Concejo no aparece únicamente en los compromisos; asi, en 1476, se pregona una ordenanza en la que, entre otras cosas, se manda «que ningund carnicero non sea osado de vender ninguna carne, salvo los que se obligaron de dar carne a la çibdad" (/dem. Actas, 1476, fol. $\left.60^{\prime}\right)$

${ }^{86}$ Los obligados de 1432 se comprometen a udar carne abasto segund que lo ellos acostumbran de dar e matar cada dia» (AMB, Actas, 1432, fol. 72). Juan Sánchez de Estrada se obligará a "dar carne abasto de carnero e de vaca todos los días que fueren de carne...". Por cada día que incumpla la norma pagará una pena de $1.000 \mathrm{mrs}$. (Idem, 1436, fols. 14' y ss. Condiciones del arrendamiento de 1436). En 1485 se señala en el contrato que los bancos «estén de continuo en todos los dias de carne de mañana fasta la noche forneçidos de carne" (idem, Actas, 1485, fols. 14'-15). Pena por dia no abastecido de 300 mrs. en $14 \nmid 1$ (Idem, 1411, fol. 40), de $100 \mathrm{mrs}$. en 1427 (Idem, 1427, fols. 96-97), de $300 \mathrm{mrs}$. en 1463 (Idem, 1463, fol. 63) y otros.

87 En agosto de 1476 se ordena pregonar que ningún carnicero de Burgos pueda vender carne el sábado, por granado ni por menudo, salvo hasta el domingo por la mañana, "por que mejor el pueblo sea basteçido" (AMB, Actas, 1476, fol. 60'). Unos meses más tarde, se permite su venta los sábados por la tarde, después de comer (Idem, Ibidem, fol. 67'). En 1480 se les da licencia para que, durante agosto, puedan matar y vender los sábados, a los foráneos, cuatro vacas (ldem, 1480, fol. 66). 
entre las partes en materia de precios, o por imposición de la ciudad si no se ha conseguido un acuerdo. El compromiso puede ser realizado de forma conjunta por todos los carniceros, o a través de pequeños grupos que se obligan a abastecer una carnicería determinada. En estos momentos iniciales, los elementos centrales del acuerdo son, sencillamente, la exigencia de aprovisionamiento, los tipos de carne suministrados, la duración del abasto - normalmente, por un año, desde la fecha en que se ha realizado el acuerdo hasta Carnestolendas del año posterior- y, por supuesto, los precios de venta ${ }^{88}$.

Podria afirmarse que desde 1427 y hasta mediada la década de los Setenta se extiende un periodo distinto, caracterizado por una relativa indefinición, durante el cual no existe un procedimiento único para designar los obligados. Las quejas contra los carniceros y la convicción de que “llevan a peoria de cada año" a la ciudad, dieron lugar a que los oficiales buscaran formas y protagonistas nuevos del abastecimiento, no limitados a los integrantes de este oficio. A punto de finalizar el año 1426 las autoridades piensan ya en la posibilidad de "poner en almoneda" el suministro de carne. Este sistema será aplicado en algunas ocasiones a lo largo del siglo. Cuando se ponga en práctica, el procedimiento seguido será el común en estos casos:

1. Promulgación por las autoridades de las condiciones del arrendamiento, entre las cuales se incluyen, además de todas las directamente referidas al abastecimiento de carne, los requisitos y plazos para efectuar las pujas.

2. Pregones públicos de la subasta.

3. Realización de posturas, estableciéndose la competencia en torno a los precios, que deben ponerse a la baja.

4. Remate en el licitador que haya realizado la oferta de precios más reducidos y recepción de fianzas.

Los pregones suelen comenzar con bastante antelación al inicio del periodo de contratación y se efectúan durante varios dias; las posturas pueden durar algún tiempo, varios meses en ocasiones, aunque es normal que en las condiciones previas o en el mismo proceso de subasta se

${ }^{88}$ Pueden verse los casos de 1411 (AMB, Actas, 1411, fols. 3 y ss.), 1423 (Idem, 1429, fols. 123 y ss.) y 1426 (ldem, fol. 15' y ss.). 
fije la fecha final del plazo de licitaciones. La realización de posturas va acompañada del pago de un "prometido" ${ }^{89}$.

Este sistema se usará de forma escasa e irregular y, además, el inicio del procedimiento no significa que exista necesariamente un remate final en un particular. Durante este periodo es frecuente observar que, al mismo tiempo que se está realizando la almoneda, el Regimiento continúa entablando conversaciones con los carniceros con el fin de llegar a un entendimiento. En principio, el punto final del proceso es siempre desconocido y depende, por lo tanto, de la capacidad de acuerdo que exista entre el Concejo y los expendedores. Asi, en 1427, a pesar de haberse realizado algunas pujas, la obligación final es asumida por éstos; por el contrario, en 1436, y no obstante haberse producido algunos contactos con ellos, la subasta es rematada en el mercader Juan Sánchez de Estrada ${ }^{90}$.

Realmente, los principales protagonistas del abastecimiento a lo largo de la parte central del siglo son los carniceros de Burgos, a quienes, según se dice en alguna ocasión, parece preferir el Concejo sobre otros particulares ${ }^{91}$. La principal forma de adjudicación del suministro será a través de las "obligaciones" asentadas con ellos, sin realización de subastas, y tras igualar, si es posible, con los oficiales, o de lo contrario, recibir de ellos, las condiciones y, sobre todo, los precios.

Ahora bien, la casuística que se establece es enormemente diversa, pudiéndose establecer muchas variantes, sobre todo en aquellos momentos, muy comunes durante estos años, en que no se consiguen unos contratos de abastecimiento satisfactorios ni suficientes (Vid. Cuadro II). Por un lado, el monopolio podia tener un carácter total, comprendiendo el conjunto de las carnicerias municipales, o parcial, refiriéndose sólo a alguna de ellas o a un número determinado de tablas en una carniceria. Del mismo modo, los obligados podian ser uno o varios o bien el conjunto del oficio. Durante los primeros años, los carniceros se obligan en bloque a abastecer la ciudad, aceptando con su presencia masiva en el Ayuntamiento las condiciones puestas con o por la ciudad ${ }^{92}$. Desde 1450, sin

\footnotetext{
"En 1436 Juan Sánchez de Estrada pone la carne por un prometido de $1.000 \mathrm{mrs}$. (AMB, Actas, 1436, fols. 14' Ss.). En 1536-1537, Gregorio Guerra consiguió un prometido de 3.750 mrs. (Heanandez Esteve, E., Noticia del abastecimiento..., pág. 100).

go Los procesos ocurridos en estos dos años son significativos en todos los sentidos descritos (AMB, Actas, 1426-27, fols. 50 y ss. y 1436, fols. 9' y ss.).

${ }^{91}$ En 1445 proponen a los carniceros «si les plazia de tomar cargo de las carneçerias de la çibdat, de las basteçer de carnes a precios razonables, que por ser vecinos, faziendo lo que deuian, que más gelo darian a ellos que a otro alguno..." (AMB. Actas, 1445, fol. 25).

${ }_{92}$ Esos serían los casos de 1427, 1432, 1436 y 1439 (Vid. Actas de los años respectivos).
} 


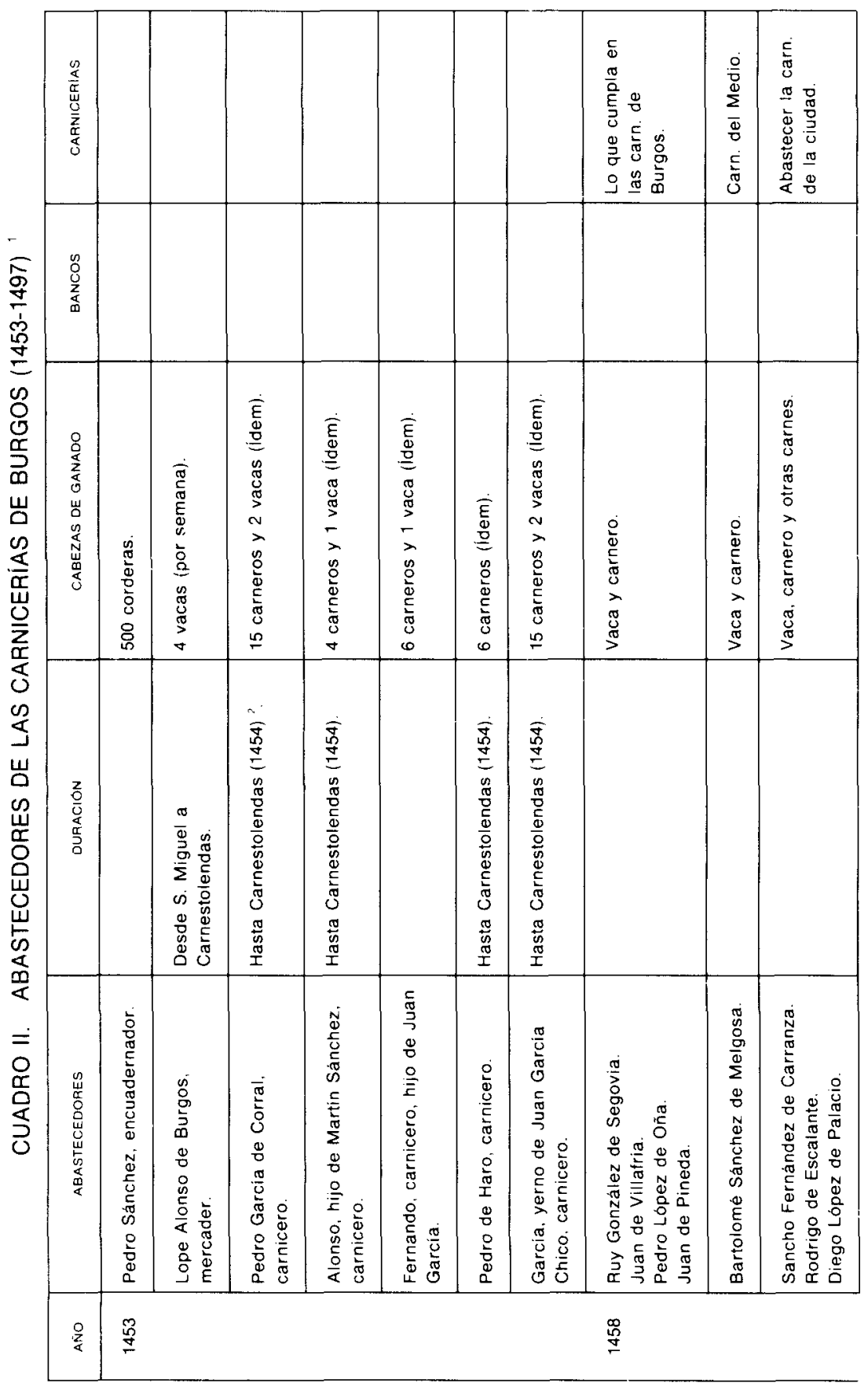


Abastecimiento urbano, mercado local y control municipal: ...

\begin{tabular}{|c|c|c|c|c|c|}
\hline 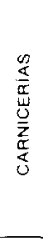 & 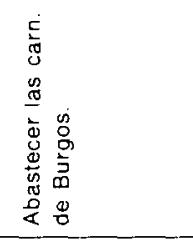 & 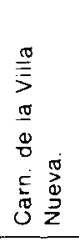 & 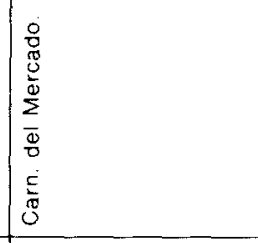 & & 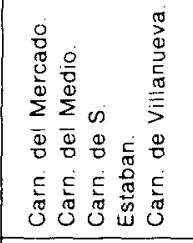 \\
\hline $\begin{array}{l}\text { on } \\
0 \\
\alpha \\
\infty\end{array}$ & & & 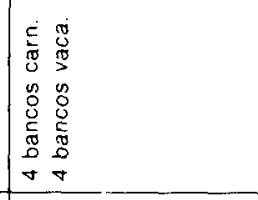 & & 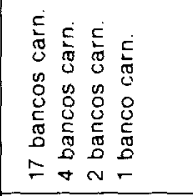 \\
\hline 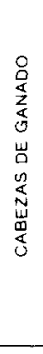 & 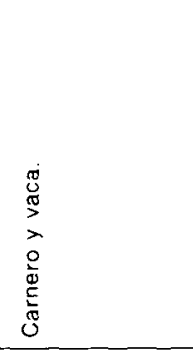 & 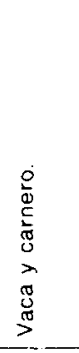 & 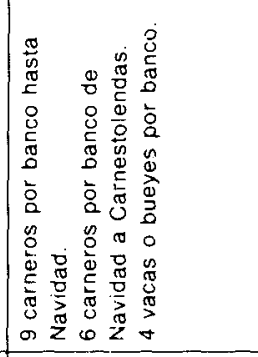 & & 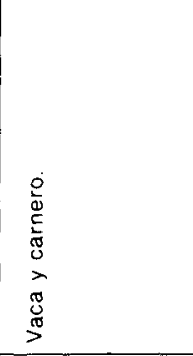 \\
\hline $\begin{array}{l}\frac{z}{z} \\
\frac{z}{u} \\
\underline{\alpha} \\
\frac{1}{\partial}\end{array}$ & 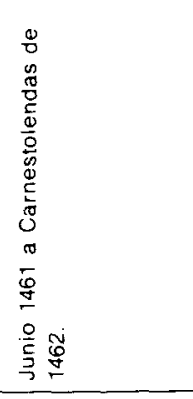 & 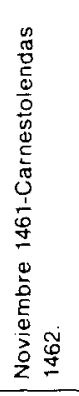 & 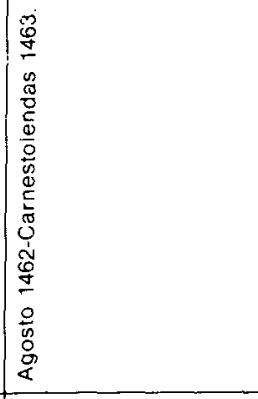 & & 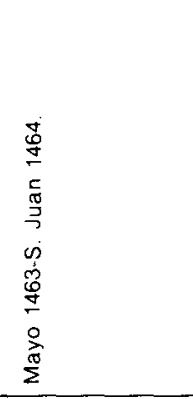 \\
\hline 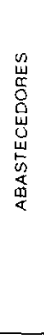 & 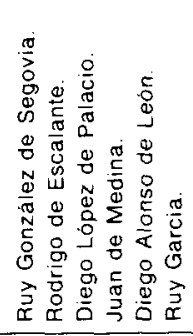 & 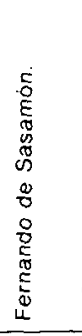 & 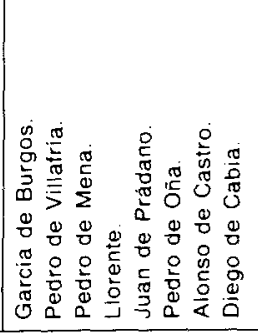 & 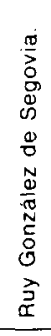 & 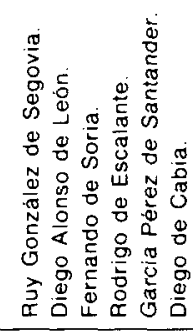 \\
\hline$\frac{8}{4}$ & $\underline{\bar{g}}$ & & $\stackrel{8}{q}$ & & $\frac{g}{q}$ \\
\hline
\end{tabular}




\begin{tabular}{|c|c|c|c|c|c|}
\hline 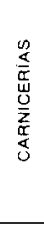 & 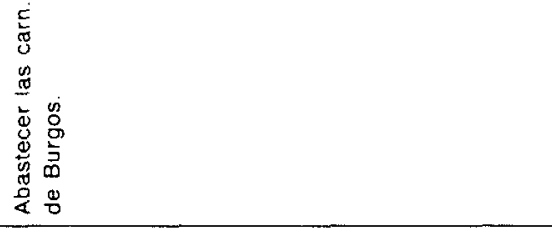 & 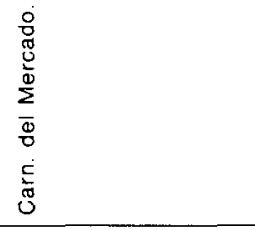 & 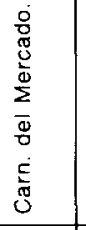 & & \\
\hline 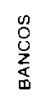 & & & & & \\
\hline 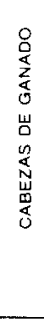 & 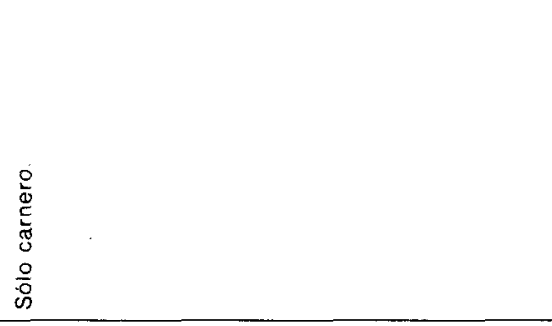 & 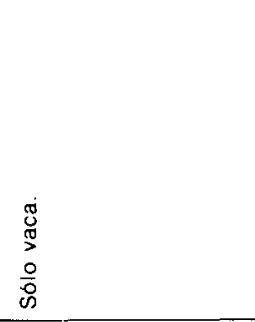 & $\begin{array}{l}\dot{0} \\
\stackrel{0}{0} \\
\stackrel{0}{0} \\
0\end{array}$ & 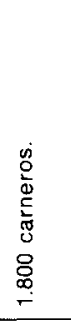 & 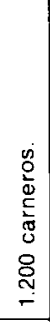 \\
\hline 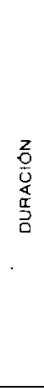 & 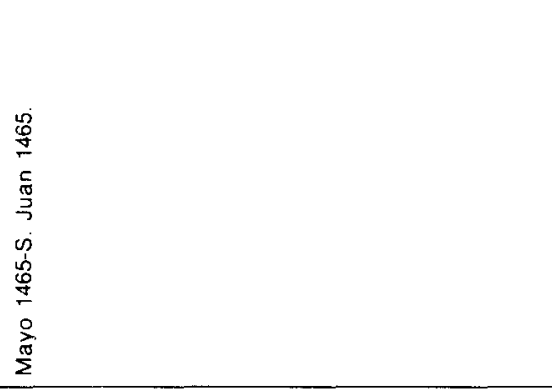 & 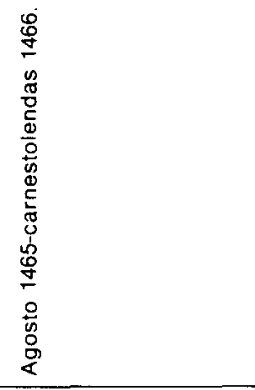 & 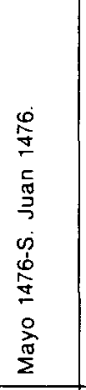 & 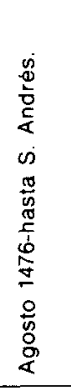 & 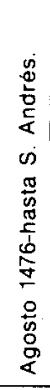 \\
\hline 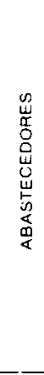 & 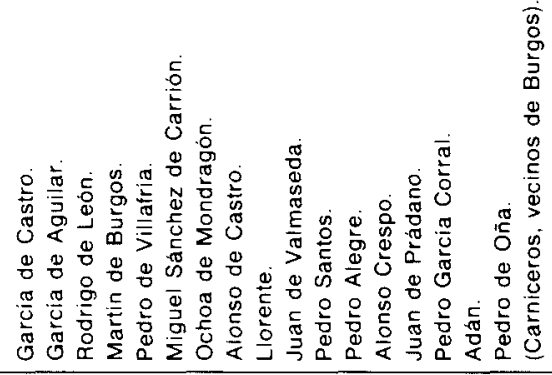 & 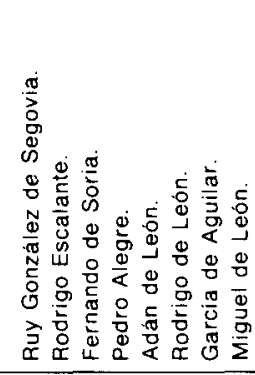 & 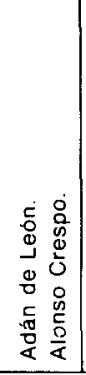 & 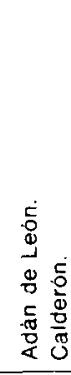 & 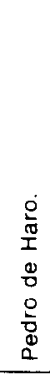 \\
\hline$\stackrel{\vec{z}}{\alpha}$ & \multicolumn{2}{|l|}{ 兽 } & \multicolumn{3}{|l|}{$\underline{z}$} \\
\hline
\end{tabular}


Abastecimiento urbano, mercado local y control municipal: ...

\begin{tabular}{|c|c|c|c|c|c|c|c|c|c|c|c|c|}
\hline 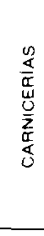 & & & 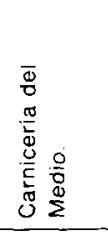 & & & & & 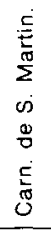 & & 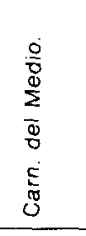 & 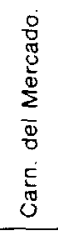 & 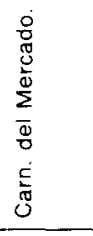 \\
\hline 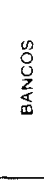 & & & & & & & & & 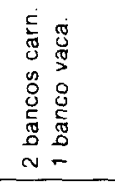 & 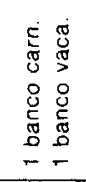 & 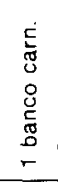 & 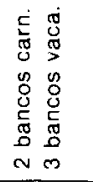 \\
\hline 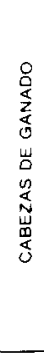 & 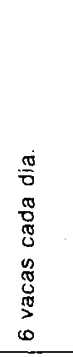 & 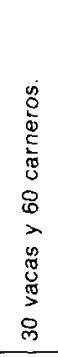 & 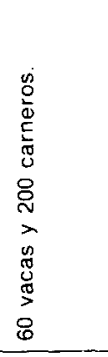 & 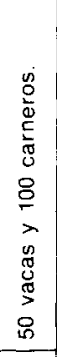 & 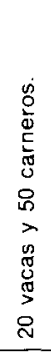 & 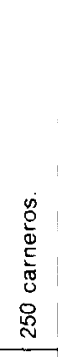 & 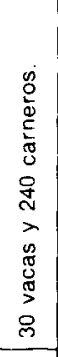 & 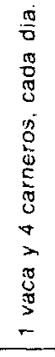 & 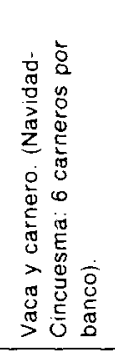 & $\begin{array}{l}\underline{E} \\
\stackrel{E}{\mathbf{v}} \\
\end{array}$ & 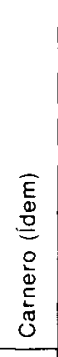 & 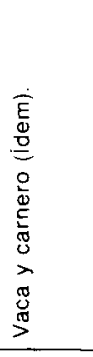 \\
\hline $\begin{array}{l}\frac{2}{0} \\
\frac{0}{0} \\
\frac{\alpha}{2} \\
0\end{array}$ & 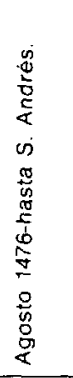 & 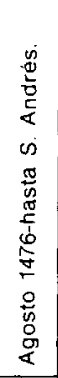 & 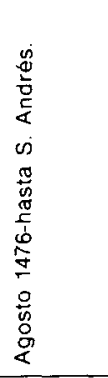 & 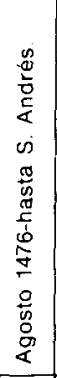 & 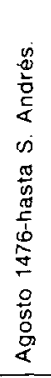 & 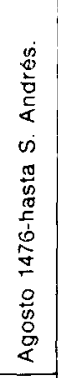 & 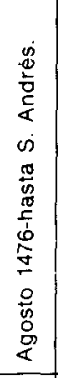 & 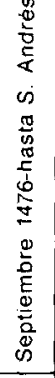 & 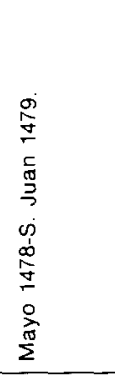 & $\begin{array}{l}E \\
\underline{\mathbb{D}} \\
\underline{\underline{\Xi}}\end{array}$ & 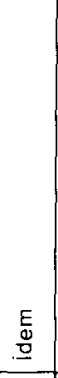 & 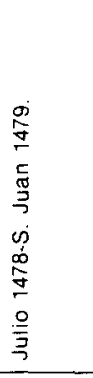 \\
\hline 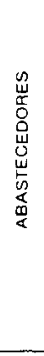 & 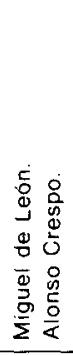 & 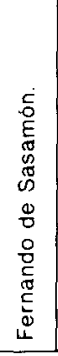 & 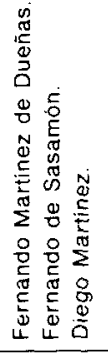 & $\begin{array}{l}0 \\
0 \\
0 \\
0 \\
0 \\
0 \\
0 \\
0 \\
0 \\
0 \\
\end{array}$ & & 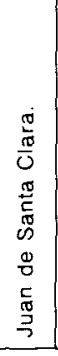 & $\begin{array}{l}0 \\
0 \\
0 \\
8 \\
0 \\
5 \\
0 \\
3 \\
\end{array}$ & 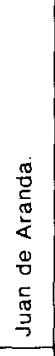 & 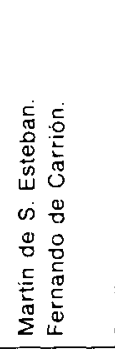 & 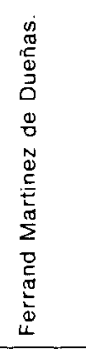 & 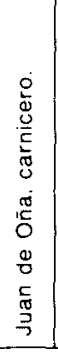 & 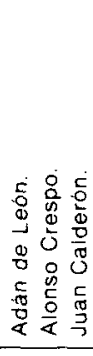 \\
\hline$\frac{J}{\alpha}$ & \pm & & & & & & & & 主 & & & \\
\hline
\end{tabular}




\begin{tabular}{|c|c|c|c|c|c|c|c|c|c|c|c|}
\hline 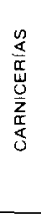 & & & & & & 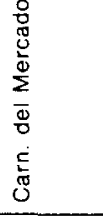 & & & & & $\begin{array}{l}\frac{0}{0} \\
\frac{0}{\Sigma} \\
\overline{0} \\
0 \\
\overline{0} \\
0 \\
0\end{array}$ \\
\hline 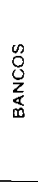 & 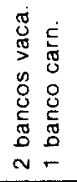 & 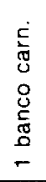 & 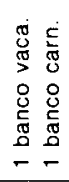 & 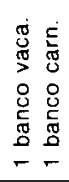 & 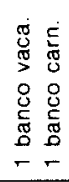 & 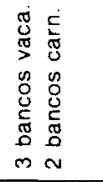 & 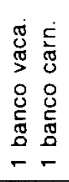 & 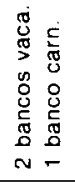 & 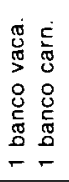 & 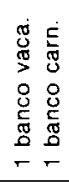 & 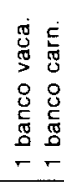 \\
\hline 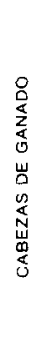 & 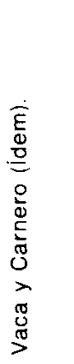 & $\begin{array}{l}0 \\
\stackrel{0}{0} \\
\frac{5}{0} \\
0\end{array}$ & 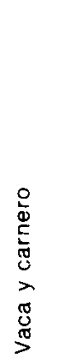 & $\begin{array}{l}E \\
\text { E } \\
\text { D. }\end{array}$ & $\begin{array}{l}\underline{E} \\
\stackrel{g}{0}\end{array}$ & 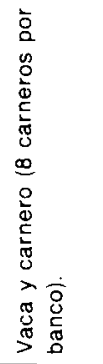 & 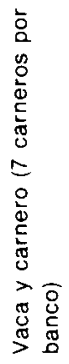 & $\begin{array}{l}E \\
E \\
\text { DO }\end{array}$ & 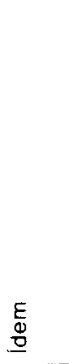 & $\begin{array}{l}\underline{E} \\
. \underline{\underline{\Xi}}\end{array}$ & $\begin{array}{l}\underline{E} \\
\stackrel{E}{\underline{D}}\end{array}$ \\
\hline 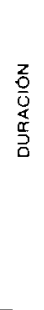 & $\begin{array}{l}\frac{0}{9} \\
\frac{9}{ \pm} \\
\frac{5}{5} \\
\frac{\pi}{3} \\
0 \\
0 \\
0 \\
0 \\
\frac{1}{5} \\
\frac{0}{3} \\
\frac{0}{3}\end{array}$ & $\begin{array}{l}\underline{E} \\
\underline{\mathbb{U}} \\
\underline{0}\end{array}$ & 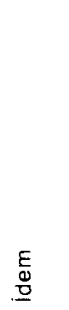 & $\begin{array}{l}E \\
\text { E. } \\
\text { DO }\end{array}$ & 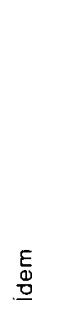 & 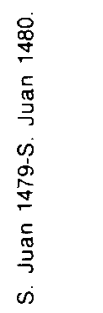 & E & $\begin{array}{l}E \\
\underline{D} \\
\underline{0}\end{array}$ & $\begin{array}{l}\underline{E} \\
\stackrel{\mathbb{D}}{\underline{D}}\end{array}$ & $\begin{array}{l}E \\
\underline{D} \\
\underline{D}\end{array}$ & $\begin{array}{l}E \\
E \\
0 \\
\underline{0}\end{array}$ \\
\hline 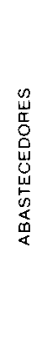 & 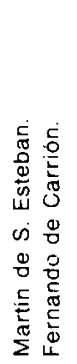 & 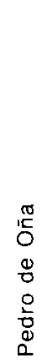 & 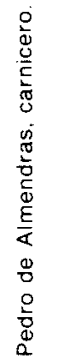 & 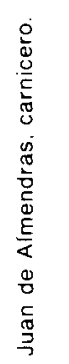 & 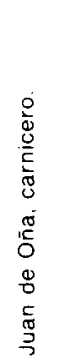 & 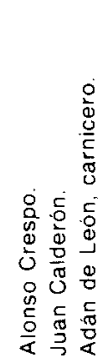 & 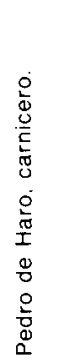 & 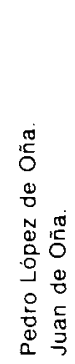 & 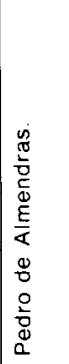 & 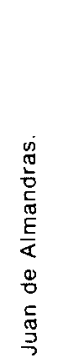 & 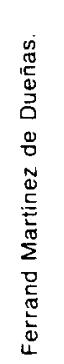 \\
\hline$\frac{z}{\alpha}$ & 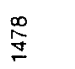 & & & & & $\begin{array}{l}0 \\
\stackrel{\sigma}{\sigma}\end{array}$ & & & & & \\
\hline
\end{tabular}


Abastecimiento urbano, mercado local y control municipal: ...

\begin{tabular}{|c|c|c|c|c|c|c|c|c|c|c|c|}
\hline 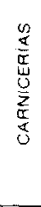 & 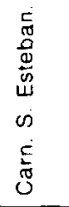 & 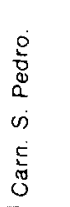 & 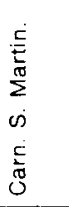 & 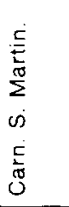 & 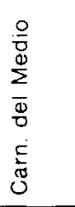 & & & & $\begin{array}{l}\dot{0} \\
\frac{0}{0} \\
0 \\
2 \\
\dot{0} \\
\dot{E} \\
\dot{0} \\
0\end{array}$ & 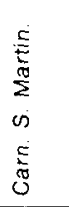 & \\
\hline 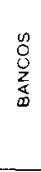 & 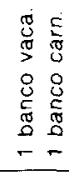 & 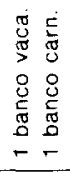 & 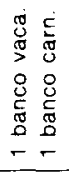 & 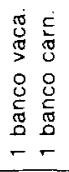 & 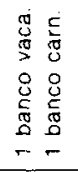 & 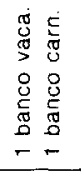 & 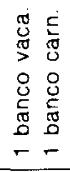 & 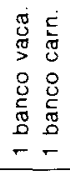 & 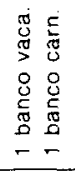 & 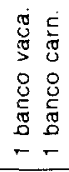 & \\
\hline 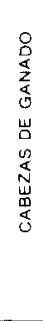 & 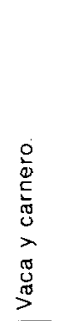 & 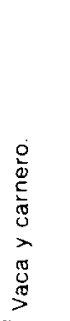 & 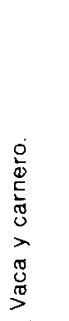 & $\begin{array}{l}\text { E } \\
\text { D. }\end{array}$ & $\begin{array}{l}E \\
\underline{D} \\
\underline{D}\end{array}$ & $\begin{array}{l}E \\
\underline{D} \\
. \underline{\Xi}\end{array}$ & 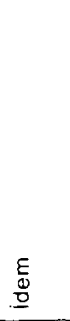 & $\begin{array}{l}\underline{E} \\
\text { Do } \\
\underline{D}\end{array}$ & $\begin{array}{l}E \\
\underline{D} \\
\text { E }\end{array}$ & $\begin{array}{l}E \\
\text { E } \\
\text { ID }\end{array}$ & \\
\hline 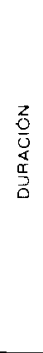 & $\begin{array}{l}E \\
\underline{D} \\
\text { IO }\end{array}$ & $\begin{array}{l}\underline{E} \\
\stackrel{D}{0}\end{array}$ & $\begin{array}{l}E \\
\text { ED } \\
\text { D }\end{array}$ & 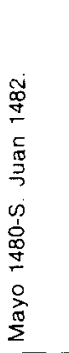 & 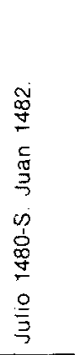 & 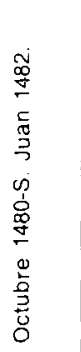 & 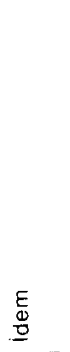 & $\begin{array}{l}\underline{E} \\
\stackrel{\underline{\sigma}}{o} \\
\underline{\underline{O}}\end{array}$ & 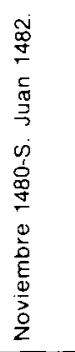 & $\begin{array}{l}\underline{E} \\
\underline{\underline{D}}\end{array}$ & \\
\hline 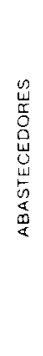 & 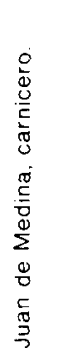 & 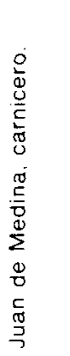 & 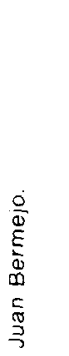 & 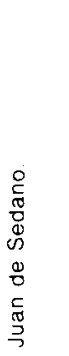 & 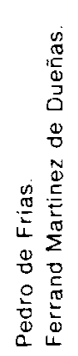 & 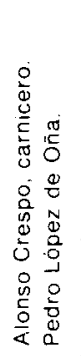 & 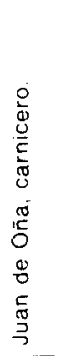 & 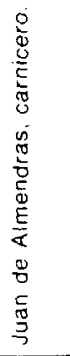 & 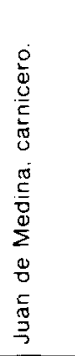 & 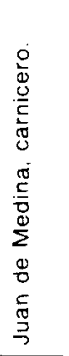 & $\begin{array}{l}.0 \\
0 \\
0 \\
0 \\
0 \\
0 \\
\frac{\pi}{0} \\
8\end{array}$ \\
\hline 总 & 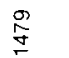 & & & $\Phi$ & & & & & & & \\
\hline
\end{tabular}




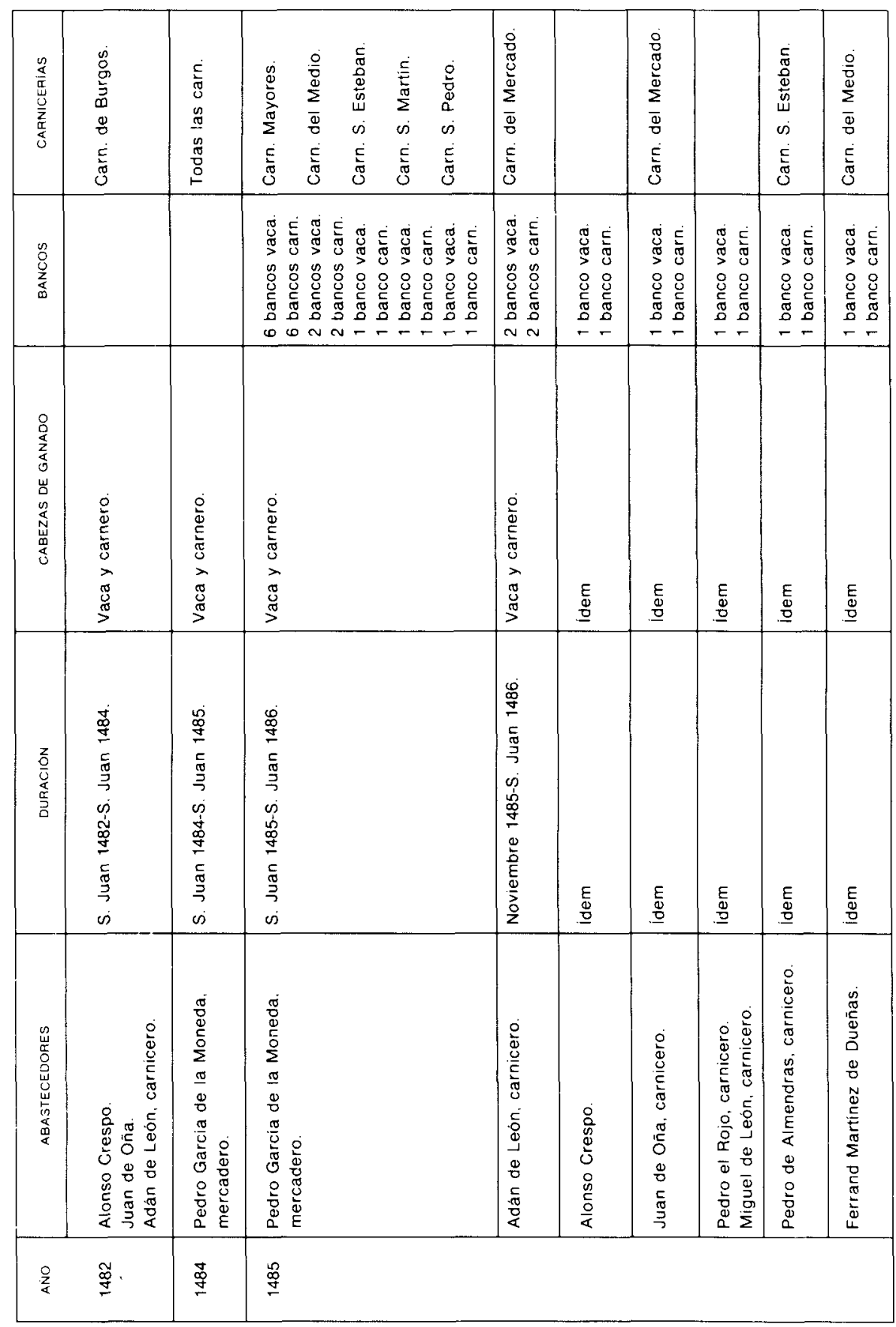


Abastecimiento urbano, mercado local y control municipal. ...

\begin{tabular}{|c|c|c|c|c|c|c|c|c|c|c|}
\hline 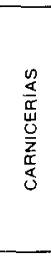 & 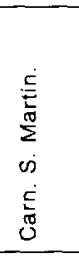 & 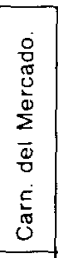 & 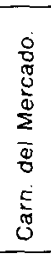 & & 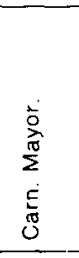 & 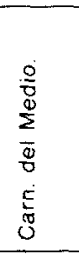 & & 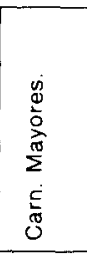 & 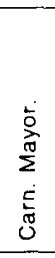 & $\begin{array}{l}\frac{1}{0} \\
\stackrel{0}{\pi} \\
\Sigma \\
\dot{L} \\
\dot{0} \\
0\end{array}$ \\
\hline 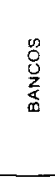 & 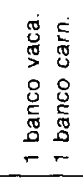 & $\begin{array}{l}0 \\
0 \\
0 \\
0 \\
0 \\
\end{array}$ & $\begin{array}{l}\dot{8} \\
\stackrel{0}{0} \\
\text { I } \\
-\end{array}$ & 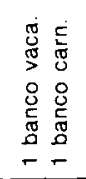 & 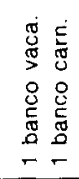 & 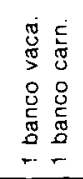 & 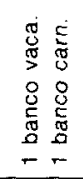 & 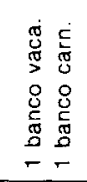 & 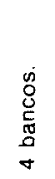 & 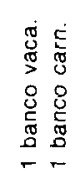 \\
\hline 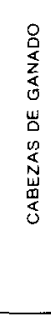 & $\begin{array}{l}\underline{E} \\
\underline{\underline{0}} \\
\end{array}$ & $\begin{array}{l}\stackrel{8}{0} \\
\stackrel{\pi}{>}\end{array}$ & 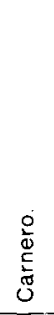 & 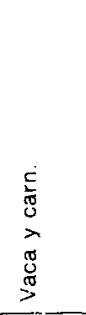 & $\begin{array}{l}\underline{E} \\
\underline{\underline{D}} \\
\end{array}$ & $\begin{array}{l}\underline{E} \\
\underline{\underline{\underline{D}}} \\
\end{array}$ & $\begin{array}{l}\underline{\underline{w}} \\
. \underline{\underline{0}} \\
\end{array}$ & $\begin{array}{l}\underline{\underline{z}} \\
\underline{\underline{\underline{z}}} \\
\end{array}$ & $\begin{array}{l}E \\
\text { E. } \\
\underline{D} \\
\end{array}$ & $\begin{array}{l}\underline{E} \\
\underline{\mathbf{g}} \\
\end{array}$ \\
\hline 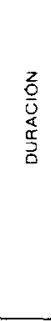 & $\begin{array}{l}\varepsilon \\
\underline{0} \\
. \underline{0}\end{array}$ & $\begin{array}{l}E \\
\underline{0} \\
\underline{\underline{J}}\end{array}$ & $\begin{array}{l}E \\
\underline{D} \\
\underline{D}\end{array}$ & 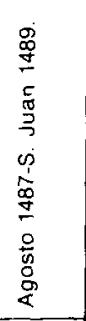 & $\begin{array}{l}\underline{\varepsilon} \\
\underline{\mathbb{a}} \\
\end{array}$ & $\begin{array}{l}\underline{E} \\
\stackrel{E}{\underline{o}} \\
\end{array}$ & $\begin{array}{l}\underline{\underline{\mathbb{v}}} \\
\underline{\underline{E}}\end{array}$ & $\begin{array}{l}\underline{E} \\
\stackrel{\mathbb{D}}{-} \\
\end{array}$ & $\begin{array}{l}E \\
\stackrel{\mathbb{D}}{\Xi} \\
.\end{array}$ & $\begin{array}{l}\underline{E} \\
\underline{\underline{D}} \\
\end{array}$ \\
\hline 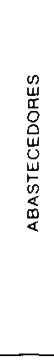 & 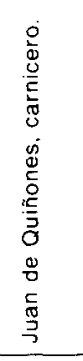 & 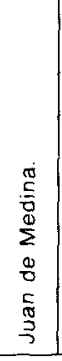 & $\begin{array}{l}10 \\
0 \\
0 \\
0 \\
0 \\
0 \\
0 \\
0 \\
0 \\
0 \\
\end{array}$ & 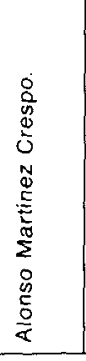 & 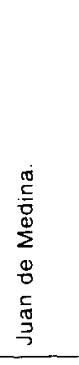 & 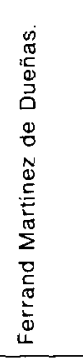 & $\begin{array}{l}\frac{0}{0} \\
\alpha \\
\bar{\alpha} \\
0 \\
\circ \\
0 \\
0 \\
0\end{array}$ & 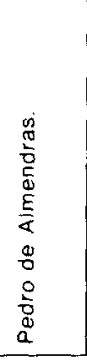 & 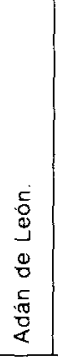 & 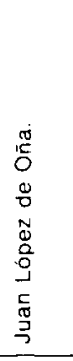 \\
\hline 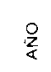 & 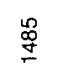 & & & 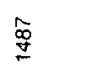 & & & & & & \\
\hline
\end{tabular}


JUAN A. BONACHIA HERNANDO

\begin{tabular}{|c|c|c|c|c|c|}
\hline 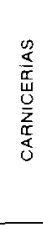 & 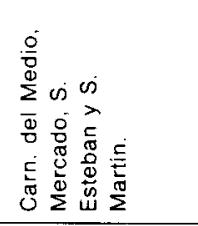 & 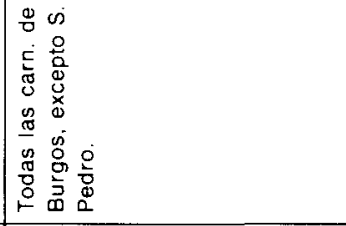 & 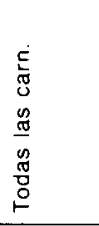 & 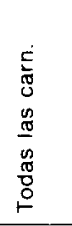 & 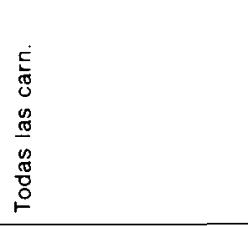 \\
\hline $\begin{array}{l}0 \\
0 \\
0 \\
0 \\
\varpi\end{array}$ & & & & & \\
\hline 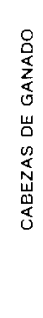 & 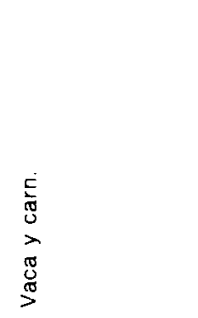 & 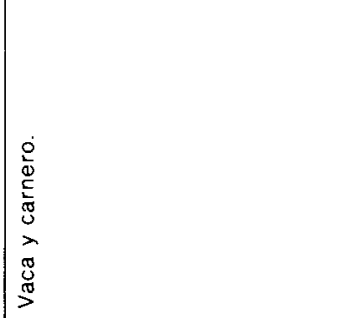 & 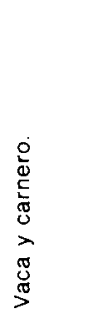 & 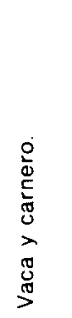 & 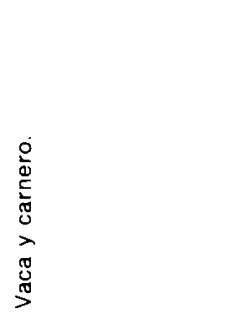 \\
\hline 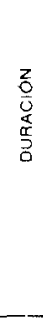 & 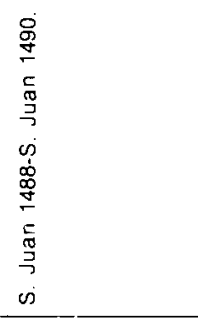 & 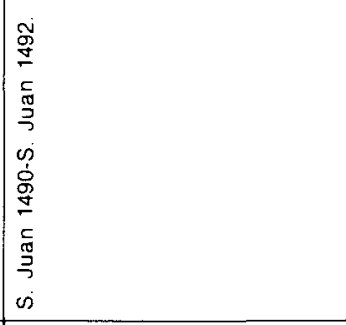 & 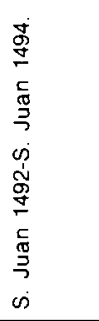 & 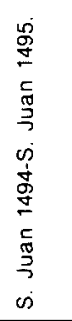 & 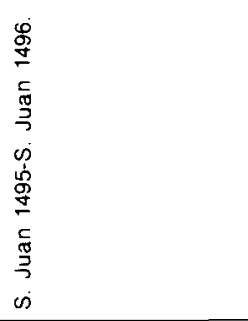 \\
\hline 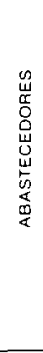 & 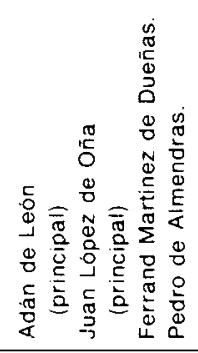 & 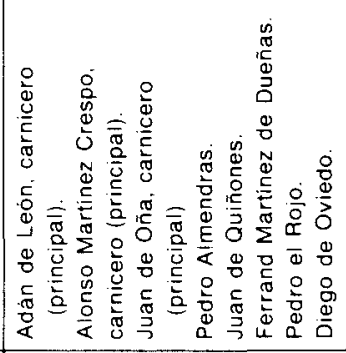 & 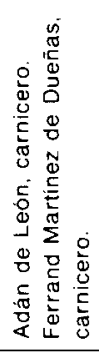 & 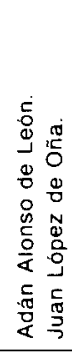 & 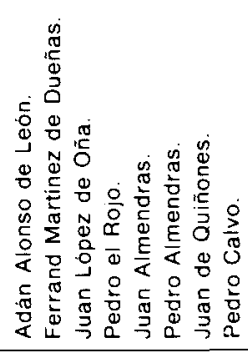 \\
\hline 孚 & \begin{tabular}{l}
$\infty$ \\
$\substack{\infty \\
\multirow{J}{*}{}}$
\end{tabular} & 桑 & 曽 & 䓫 & 㟢 \\
\hline
\end{tabular}


Abastecimiento urbano, mercado local y control municipal: ...

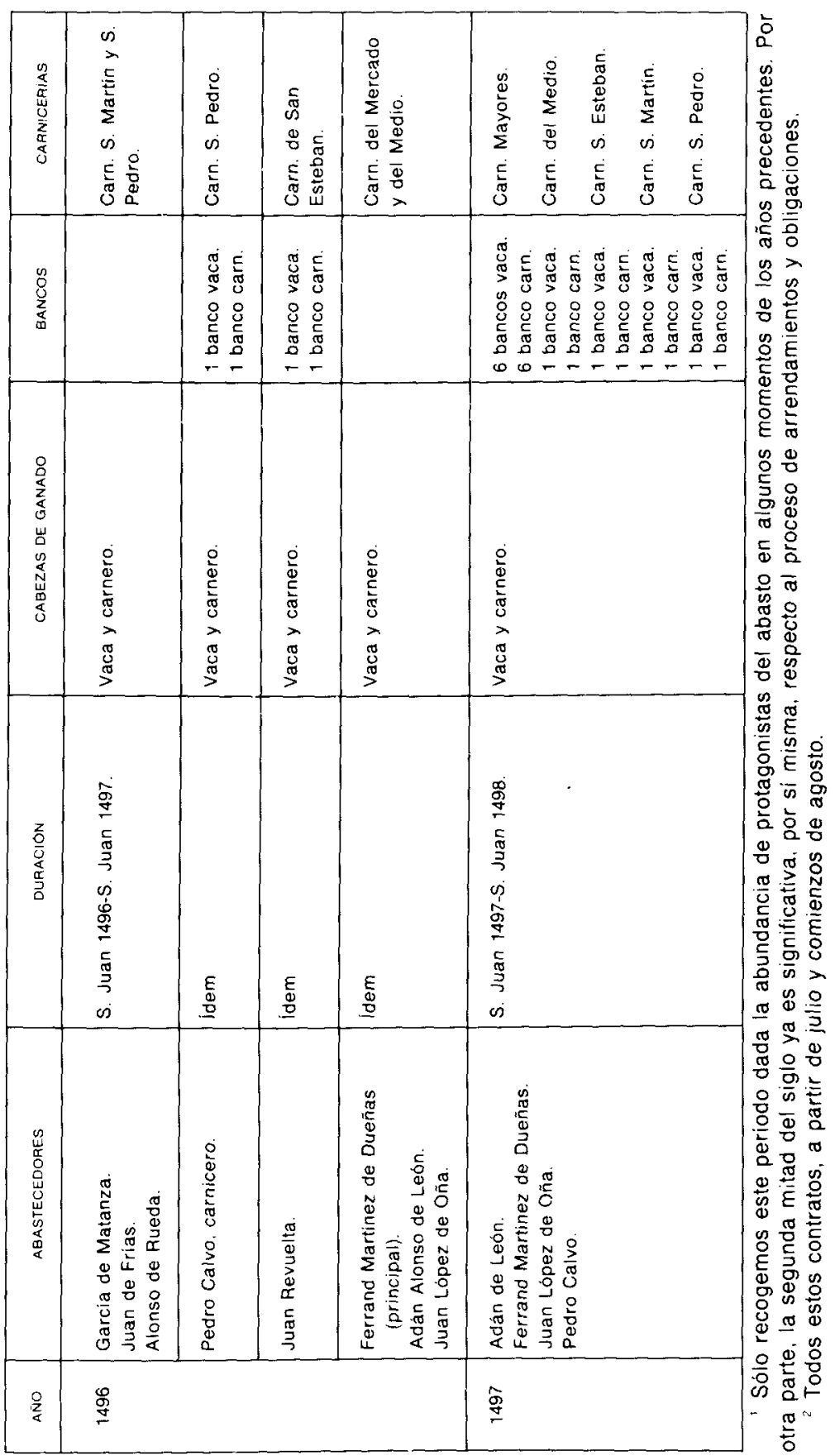


embargo, abundan las obligaciones individuales o de pequeños grupos. En tercer lugar, los contratos tienen una duración extremadamente variable. Aunque se observa una tendencia a fijar arrendamientos anuales, ello no invalida el hecho de que en bastantes ocasiones se firmaran por un tiempo inferior o superior. Asi, podremos encontrar convenios semanales ${ }^{93}$, mensuales ${ }^{94}$, o plurianuales ${ }^{95}$. La fecha de referencia final de los contratos, principalmente en aquellos que cubren plazos largos, es el dia de Carnestolendas, esto es, el comienzo de la Cuaresma. No obstante, se contempla en los últimos años una transformación dirigida a instituir la fecha final de la obligación en el dia de San Juan de junio ${ }^{96}$. Por último, los tipos y cantidades de carne contratada son también diversos. Las obligaciones pueden referirse, de forma general, a dar abasto de vaca y carnero; otras veces, conciernen a un tipo exclusivo de carne; en ocasiones, indican la aportación de un número determinado de cabezas, establecido en su totalidad, por dias o semanas, o por bancos (Cuadro II).

Los contratos parciales, tanto por la manera fragmentaria de proveer las carnicerías como por el espacio de tiempo cubierto, aminoran los problemas de abastecimiento pero en absoluto solucionan las dificultades. En cualquier caso mejoran la situación provocada en aquellos años en los que ni siquiera hay obligados, por falta de subastadores en las pujas y desacuerdo con los carniceros ciudadanos. En tales casos, el Concejo intentará paliar los apuros abastecedores mediante la emisión de ordenanzas y la búsqueda de medidas alternativas ${ }^{97}$.

El último cuarto de siglo mantiene rasgos de la época anterior (monopolios fragmentados, número de obligados por contrato...), pero se tiende a una mayor ordenación de los sistemas de arrendamiento $y$, por lo tanto, a una mayor clarificación de sus caracteristicas. Con una cierta antelación al comienzo del periodo de abastecimiento, el proceso se inicia prácticamente siempre de la misma manera: se pregona quién desea abastar de carne la ciudad, se entablan conversaciones con las personas

${ }^{93}$ En 1447, por ocho dias. Es un caso excepcional, debido a una persistente situación de desacuerdo sobre los precios entre ambas partes. Los mismos protagonistas intentan aligerar la solución "por quanto no se podrian juntar cada dia sobre el poner de la carne..." (AMB, Actas, 1447, fol. 101).

${ }_{94}$ En 1432, por tres meses y medio (Desde 19 de julio hasta 31 de octubre) (AMB, Actas, 1432, fol. 72). A veces, por menos tiempo aún (Vid. Cuadro II, los casos de 1465 y 1476).

95 En 1433: de mayo de 1433 a Carnestolendas de 1436 (AMB, Actas, 1433, fol. 148).

96 Sólo en 1476, se establece la techa de San Andrés (30 de noviembre). Tiene que ver con un momento de crisis en el abastecimiento (duración corta del contrato) y con los ritmos de pastoreo del ganado y consumo de las personas

${ }_{97}$ Sobre tales medidas se hablará más adelante. De todas las formas, pueden verse las dificultades ocasionadas por la falta de abastecedores en los años 1441 y 1447. 
Abastecimiento urbano, mercado local y control municipal: ...

que quieren contratar las carnicerías y se nombran diputados del Concejo para concertar los términos del compromiso. Aunque hay algunas subastas con remate final ${ }^{98}$, se perfila una nitida y dominante tendencia a acordar precios y condiciones con los carniceros propensos a realizar el avituallamiento. No obstante, continúan surgiendo problemas entre el Concejo y los proveedores; en cualquier caso, con el fin de evitar situaciones de escasez por desajustes de esta indole, se contempla una mayor fluidez de los mecanismos habilitados para la toma de acuerdos y la concesion de las obligaciones.

Por otro lado, también hay una mayor simplificación en lo que concierne a la duración y las fechas de los contratos. Salvo en algunos momentos concretos, como resultado de la falta de acuerdos o de previsión, las obligaciones ocupan un ciclo anual o plurianual, tomándose definitivamente como punto de inicio y final el dia 24 de junio, festividad de San Juan. El carnero y la vaca actúan como elementos de referencia principal del resto de las carnes. La cantidad aportada se resume en la frase "dar abasto suficiente", especificándose en su caso las tablas obligadas en cada carniceria y, a lo sumo, el número mínimo de cabezas que deben ser sacrificadas y pesadas por dia y por banco.

Los contratos, aun siendo de naturaleza parcial, tienden a cubrir en conjunto la mayor parte o la totalidad de los despachos municipales, siempre con el propósito obvio de soslayar problemas de carestía. Este objetivo primordial de la politica municipal da lugar a que, en los casos de incumplimiento de las obligaciones, el Concejo pueda "quitar" las carnicerias o tablas contratadas. En mayo de 1485 , Pedro Garcia de la Moneda contrató con la ciudad el abasto de 22 bancos repartidos por todas las carnicerias de Burgos, por un plazo de un año. Sin embargo, pocos meses después, a comienzos de noviembre, él y su fiador alegaban que ueran perdidos por servir a la ciudad y no podian cumplir lo que están obligados". Además de proceder a su embargo por incumplimiento de contrato, el Concejo traspasó inmediatamente el abastecimiento a diversos carniceros de la ciudad, que cubrieron el servicio por tablas ${ }^{99}$. Es decir, las prioridades de la politica comercial de la ciudad priman sobre la observancia de los contratos en todos sus términos. Este tipo de ac-

En 1482, con una duración inicial de tres años (AMB, Actas, 1481, fol. 66 y ss.) y 1484 por un año (ldem, 1484, fols. 10 y 26). En ambos casos participa en la licitación Pedro Garcia de la Moneda, mercader, el único personaje no-carnicero que aparece en este periodo como proveedor de todas las carnicerias municipales.

94 AMB, Actas, 1485, fol. 14', 39 y ss. Idem, 1486, fol. 19. En 1481 se había producido un caso similar con otro carnicero, aunque referido en esta ocasión únicamente a dos bancos (Idem, 1481, fol. 44). 
tuación, aun por motivos diferentes, no es exclusiva de este periodo, pudiéndose encontrar algún precedente en años anteriores. En 1458, dos hermanos carniceros, Fernando de Castro y Garcia Sánchez, que habian tomado las carnicerias el año anterior, se quejaron de ciertas irregularidades y condicionaron su permanencia en el servicio a su rectificación por el Concejo. Finalmente y por mutuo acuerdo dieron por nulo el compromiso y los oficiales entregaron el abasto a diversos carniceros ${ }^{100}$. En 1462, ante las exigencias de Ruy González de Segovia, las autoridades otorgaron parte de la carniceria, por bancos, a un grupo de ocho carniceros ${ }^{101}$.

Por último, se advierte también una interesante evolución del sistema de obligados en lo que se refiere a sus protagonistas. En las primeras décadas del siglo los carniceros aceptaban las condiciones municipales y se obligaban en bloque. En 1411, 17 carniceros prometieron dar abasto «por si y por los otros, que dijeron vendrian a obligarse»; finalmente realizaron el compromiso 30 individuos ${ }^{102}$. En 1433, fueron 23 los carniceros que se obligaban "de mancomún" ${ }^{103}$. Más o menos desde mediados del Cuatrocientos, sin embargo, no se presentan unidos a las obligaciones, que realizan individualmente o en pequeños grupos. Además, se está imponiendo de modo progresivo una tendencia a la concentración del abastecimiento en unos pocos individuos. Como se observa en los Cuadros II y III, los contratos de los últimos 22 años se centralizan mayoritariamente en cinco personas -Pedro de Almendras, Alonso Crespo, Adán Alonso de León, Juan López de Oña y Ferrand Martinez de Dueñas-, siendo los tres últimos quienes más participan en los arrendamientos, quienes más volumen de despacho controlan y los que, en los últimos momentos, aparecen como "principales» de los convenios. Parece, pues, denotarse, una clara inclinación - que habria que ratificar en años venideros-, a reunir en unas pocas manos el control del mercado de la carne.

\section{C) Los agentes comerciales}

Como se ha comprobado en lineas anteriores, el Concejo utiliza un sistema de prioridades a la hora de otorgar el abasto y expendición de carne. En el momento de establecer contactos o llegar a acuerdos - que giran sustancialmente alrededor de los precios del producto-, siempre

\footnotetext{
100 AMB, Actas, 1458, fols. 16'-23'

101 AMB, Actas, 1462, fols. 106-107

102 AMB, Actas, 1411, fols. 40-40'.

${ }^{103}$ AMB, Actas, 1433, fols. 148 y ss.
} 
Abastecimiento urbano, mercado local y control municipal: ...

se da preferencia a los carniceros. Hay un caso excepcional que avala esta predilección por los integrantes del oficio. En 1428, tras no haberse llegado a ningún convenio con los carniceros («rebeldes contra la ciudad en no querer venir a buena igualanza»), tomó el abasto el regidor Pedro Sánchez de Frias. Sin embargo, tras una oferta realizada por aquéllos en diciembre de ese mismo año, rápidamente surgieron voces solicitando su perdón a la vez que la restitución de las carnicerias. Tras largas discusiones, asi se hizo, después de fijar el pago de una satisfacción y diversas contrapartidas al arrendador cesante ${ }^{104}$.

No es éste, sin embargo, el caso más normal. Contrariamente, cuando Concejo y carniceros no consiguen un avenimiento - fenómeno nada infrecuente por otro lado-, los oficiales acuden a cualquier otra persona o grupo de personas, sean vecinos de la ciudad o foráneos, carniceros o no, siempre en orden a asegurar un buen abastecimiento.

No faltan muestras, en caso de necesidad, de este recurso a "omes carniceros de fuera parte", como se señala en $1411^{105}$. A alguno le vemos actuar en Burgos: en 1452, las autoridades ciudadanas tuvieron que recordar que Pedro Martinez de Segovia, carnicero foráneo, tenía licencia municipal para ejercer el oficio y, en consecuencia, ordenaron que se le devolvieran las prendas que se le habian tomado por cortar y vender vaca y carnero en un banco de la ciudad ${ }^{106}$. Otras veces se hacen propuestas en el Regimiento de entregar las tablas a "quien mejor barato feciere a la çibdat", como se pretendia en $1447^{107}$, o se toma la decisión de arrendarlas «a los dichos carniçeros o a otros si fallaren que farian mejor mercado a la çibdad, agora sea de la çibdad, agora de fuera", tal como se ordena en $1495^{108}$.

Por norma general aunque no exclusiva, los arriendos por almoneda pública que conocemos durante el periodo estudiado suelen tener como rematantes a individuos que no son carniceros de profesión. Ese es el caso de Juan Sánchez de Estrada, mercader, licitador del abasto de 1427

${ }^{104}$ AMB, Actas, 1429, fols. 5 y ss

ios AMB, Actas, 1411, fol. 3. En 1496 se tantea ia posibilidad de que un vecino de Becerril tome la carniceria de Burgos (/dem, 1496, fol. 90). Vid. para otros casos, págs. 93-94 de este trabajo.

${ }_{106}$ AMB Actas, 1452, fols. 11 y 12

${ }^{107}$ AMB, Actas, 1447, fol 114.,

${ }^{108}$ AMB, Actas, 1495, fol. 59'. En 1441, ante las dificultades de abastecimiento por las que atravesaba la urbe, se solicitó que "diesen en ello alguna vía, agora por manera de renta - como por prestido que prestasen las vezindades o por otra qual quier manera" (/dem. Actas, 1441, fol. 23). Otro caso similar, en 1486 (ldem, 1486, fol. 25). 
y adjudicatario de la subasta de $1436{ }^{109}$, o del tambièn mercader Pedro Garcia de la Moneda, a quien le vemos pujando sin éxito, en 1481, frente a los más poderosos carniceros de la ciudad, y obteniendo el remate $-y$ fracasando más tarde- en el arriendo de 1485-1486. Pero el ejemplo más significativo es el del regidor Pedro Sánchez de Frias, una persona con fuertes intereses en esta rama de la alimentación ${ }^{110}$, a quien se arrendaron las carnicerias en 1428 por un periodo de 4 años, pero que, por las causas que hace poco hemos apuntado, apenas se mantuvo en su puesto hasta mediados de marzo de 1429. El ejemplo es interesante por lo que representa, ya que es el único momento a lo largo de todo el siglo en que se advierte a un oficial del Regimiento participando activamente en el abastecimiento de carne a la ciudad. A partir de ahi nunca se constata la presencia de integrantes del Ayuntamiento en la provisión de las carnicerias. De hecho, su injerencia en estos asuntos es mal vista por una buena parte de los miembros del Ayuntamiento y acabará siendo prohibida por el monarca.

A principios de 1436, Pedro Sánchez de Frias propuso que se pusiese a subasta, a la baja y por cuatro años, el avituallamiento de carne en Burgos. Alvar Garcia de Santamaria no opuso ninguna objeción pero condicionó el arrendamiento al hecho de que ningún alcalde, regidor, merino ni escribano mayor participara en él. Su argumento se basaba en el principio de que no podian ser juez y parte en caso de que se produjeran incumplimientos ya que, además, se vería en peligro la ejecución de las penas ${ }^{111}$. Tanto Pedro Sánchez como Juan Sánchez de Estrada - quienes curiosamente ya habian participado algunos años antes en arrendamientos de la carne- arguyeron que no era justo introducir un impedimento de esa naturaleza, puesto que los oficiales podian efectuar pujas más baratas que otros licitadores y beneficiar con ello a la ciudad. En la discusión acabaron interviniendo las collaciones, a través de sus procuradores - Juan Sánchez era uno de ellos-, y sostuvieron la opinión de que el abastecimiento debia ser puesto por cualquiera que diera más provecho a los vecinos, aunque fuera regidor o alcalde. Como sabemos, fue éste

${ }^{109}$ Procurador de las vecindades, fiador de los arrendadores de las rentas de Burgos (1427) o arrendador él mismo de otras rentas, como la de la carne (1436-1439), se trata de un personaje que, durante el segundo cuarto del siglo $x \mathrm{v}$, tiene una participación bastante activa en la vida politica del Ayuntamiento

110 Vid., págs. 98 y 103 de este estudio.

111 "que le pareçía que el alcalde o el regidor que auia de ser juez para aquel que la arrendase fazerie complir e guardar las condiçiones con que arrendaba que no deuia ser arrendador en la tal renta, ni el fiel de la çibdat ni otra persona alguna non esecutaría ni osaria esecutar pena alguna en el alcalde ni en el merino ni en el regidor aunque en ella cayese" (AMB, Actas, 1436, fol. 10). 
Abastecimiento urbano, mercado local y control municipal: ...

último quien finalmente remató la subasta y firmó el contrato con la ciudad ${ }^{112}$.

Pero las reticencias de Alvar Garcia y otros componentes del Ayuntamiento - la "mayoria era de su opinión» se había dicho en los debates de 1436 - tuvieron su fruto poco tiempo después. En 1441, el monarca Juan II prohibió bajo graves penas que ningún oficial, "ni sus lugartenientes, ni otros por ellos", pudiera vender viandas y cosas por menudo en Burgos. Las razones esgrimidas fueron prácticamente las mismas que las expuestas por Alvar Garcia ${ }^{1: 3}$. Esta ley permaneció en vigor en el futuro y sólo en casos de extrema necesidad fue levantada la prohibición para que las autoridades municipales pudieran hacerse cargo de las carnicerias ${ }^{114}$.

¿Quiénes eran los carniceros? Este concepto, tal como le hallamos en las fuentes, tiene dos contenidos diferentes. Evidentemente se refiere a aquellos profesionales cuya labor es el sacrificio, tajo y pesaje de las carnes en los bancos públicos. Pero también concierne a los carnicerosabastecedores, personas cuya función es proveer las tablas y que pueden o no practicar el oficio. Ciertamente, no es necesario que el individuo que expende ccincida con el mismo que abastece, aunque muchas veces ambos conceptos se mezclan y confunden en un mismo hombre. Por ejemplo, cuando, a comienzos de siglo, los carniceros de Burgos se hacen cargo, en común, del abasto de carne; o, por ejemplo, en aquellas personas que toman un número reducido de despachos para abastecer. En ocasiones semejantes, el carnicero podria realizar a la vez las dos funciones: la de abastecedor y la de vendedor ${ }^{115}$.

112 AMB, Actas, 1436, fols. 9' a 28 '.

113 "... me es fecha relaçión que algunos ofiçiales del regimiento desa çibdad o otros por ellos han usado e usan de vender pan e vino e carne e pescado por menudo, de lo qual diz que se recresçe daño a los vezinos e moradores de la dicha çibdad, asy por se non vender las tales cosas por los pesos ni a los preçios que se deuen vender, como porque los executores que la dicha çibdad pone no se atreven a los prendar quando por lo tal deuen ser prendiados, e sy algunas vezes ovieren de fazer las tales prendas les son defendidas; de lo qual se ha recresçido algunos escándalos e cada que algunos regidores de la dicha çibdad en ello querian proveer, que los otros regidores a quien tañe, por sy e asy mesmo con fauor de algunos parientes que tiene el dicho regidor gelo enbargan, por manera que en esta parte no se ha guardado ni guarda lo que cunple a mi seruiçio e a pro común de la dicha çibdad..." (AMB, Actas, 1441, fols. 79-79'; Carta regia de 1441-X-15, Burgos).

${ }^{114}$ En 1447, ante la gran falta de carne que habia en Burgos, y dado que nadie queria tomar las carnicerias, acordaban «alçar qual quier juramento que tengan fecho alcaldes y regidores e lo dan por ninguno, para que las puedan ellos o qual quier dellos tomar abasteçer..." (AMB, Actas, 1447, fol. 105')

${ }^{115}$ En 1476, sólo pueden vender carne los que se han obligado a darla a la ciudad (AMB, Actas, 1476, fol. 60'). Es un ejemplo claro de concurrencia de las dos funciones. El dato 
Pero es absurdo pensar que cuando una sola persona, o un pequeño grupo a lo sumo, se hace cargo del abastecimiento, se dedique a realizar simultáneamente, aunque sea carnicero de oficio, ambas labores: proveer $y$, al mismo tiempo, matar, cortar y pesar en alrededor de veinte bancos. En Burgos, a fines de la Edad Media, un carnicero no tiene por qué ser, necesariamente, un comerciante de carne al por menor.

Esa diferencia aparece, en algún momento, citando a éstos últimos como "carniceros mayores" o "carniceros principales» "16. ¿Quiénes actúan entonces como expendedores?. La información en este sentido es bastante limitada. En 1461, al obligarse seis carniceros a abastecer las carnicerías municipales, el Concejo se comprometió a apremiar al resto de "los carniçeros que pesan la dicha carne en esta dicha çibdad e lo tienen por ofiçio que, pasándoles su derecho acostumbrado, sean tenidos de lo pesar" por los obligados ${ }^{117}$. Un año después tuvieron que insistir en ello puesto que ningún carnicero queria cortar carne a los "carniceros mayores" ${ }^{118}$. Si esta situación se hubiera repetido en otras ocasiones a lo largo del siglo, podriamos considerar que los "carniceros menores" estaban forzados a cortar y pesar la carne provista a los bancos por los abastecedores. Sin embargo, hay otras informaciones, principalmente cuando se trata de arrendamientos realizados por subasta, que llevan a creer que los obligados se encargaban de todo el proceso, contratando sus propios expendedores, sin que fuera imprescindible la presencia de los carniceros. Al evaluar la reparación económica que había que otorgar a Pedro Sánchez de Frias por el abandono de las carnicerías que tenía arrendadas, se estableció, entre otros cargos, que se le entregaran 15.000 mrs. en concepto de salario por el trabajo realizado por "él y los suyos", y que los carniceros que se hicieran cargo del abasto le adquirieran en un precio razonable los "pertrechos de carniceria" que habia comprado a causa del contrato y que, al dejar el arriendo, ya no le eran útiles ${ }^{119}$ Pedro Sánchez, al arrendar la carne, se habia hecho cargo de todo el proceso que va desde el abastecimiento hasta la venta. Algo similar puede deducirse de la mención permanente a sus "ofiçiales» que Pedro García de la Moneda hace en el contrato suscrito en $1485^{120}$.

coincide, por otra parte, con un año en que la provisión de ganado se realiza con caracteres especiales y por un amplio numero de carniceros (Vid. Cuadro II).

${ }^{116}$ AMB, Actas, 1462, fol. 101'. Idem, 1485, fol. 30.

AMB. Actas, 1461, fol. 83.

${ }_{118}$ AMB, Actas, 1462, fol. 101'

'19 AMB, Actas, 1429, fols. 24-24'.

120 AMB, Actas, 1485, fol. 14. 
Denominaciones como "mis oficiales», «mozos», «criados», que asoman a la luz de vez en cuando, obligan a considerar la más que probable existencia de todo un grupo de individuos asalariados, banqueros o tablajeros, que trabajaban al servicio de los principales abastecedores ${ }^{121}$. Todo conduce a juzgar que, paralelo al proceso de división del trabajo, ha tenido lugar una creciente estratificación social en el interior de la profesión. La capacidad económica de los carniceros es muy diferente. Frente a la presumible potencia de gentes como Adán de León, Ferrand Martinez de Dueñas o Juan de Oña, otros se ven abocados al abandono del oficio, como Francisco de Roa en $1481^{122}$, o apenas participan de modo esporádico en el abasto de la ciudad (Vid. Cuadro ili). Por otra parte, esa diferenciación tendria un reflejo en su posición de fuerza e influencia en el seno de su organización corporativa ${ }^{123}$. Por ejemplo, tanto Adán de León como Juan de Oña aparecen casi de modo omnipresente como compromisarios de los carniceros a la hora de dilucidar debates o igualar precios con el Concejo ${ }^{124}$.

Organizados a veces en compañías ${ }^{125}$, la información que nos llega encamina hacia la hipótesis de la presencia de individuos, dentro del oficio, más acomodados, de mayores niveles de riqueza, con toda probabilidad medios o importantes propietarios de ganado, que abastecen a otros carniceros secundarios, a cuyo cargo corren las labores en las tablas, o que se sirven para ello de asalariados. Si a esto unimos, como se ha visto, la tendencia a centralizar el control del abasto en unas pocas ma-

${ }^{121}$ Su presencia está muy claramente atestiguada en los inicios del segundo tercio del siglo XVI (Hernandez Esteve, E., Noticia del abastecimiento..., págs. 46, 77-79, 103). En el período estudiado, además de los "oficiales" de Pedro Garcia de la Moneda, también tenemos conocimiento de los "mozos" de Antón Garcia, un peraire dedicado a abastecer a la urbe en los años centrales del sigio (AMB, Actas, 1453, fol. 41'), los "criados" de Adán de León (/dem, 1490, fol. 163), y, en general, los “mozos" y “criados» de los carniceros (/dem, 1486, fols, $35-35$ y 1490 , fol. 133).

122. AMB, Actas, 1481, fol. 44

${ }^{123}$ En 1426 es citado el pendón de los carniceros, junto a otros y en último lugar, al establecerse el orden que se ha de llevar en las procesiones (AMB, Actas, 1426, s. tol.). No obstante, no conocemos ninguna otra cosa sobre su estructura y organización. La pieferencia del Concejo hacia los carniceros de Burgos, la forma de acordar precios y condiciones, y acontecimientos como el de 1428-1429 pueden hacer creer en la existencia de un gremio bastante influyente. Sin embargo, todos esos sintomas pueden estar referidos simplemente al interés municipal por los que son considerados unos mejores canales de comercialización de la carne

${ }^{124}$ AMB, Actas, 1481, fol. 32; Idem, 1492, fol. 163; Idem, 1494, fols. 19' y 64 bis

${ }^{126}$ En 1426 varios carniceros actuan "por sí y por su compañia" (AMB, Actas, 1426, fol. 31'). Ruy González de Segovia habla en nombre de él y su compañia (Idem, 1462, fol. 119'). Por otro lado, las formas de realizar los contratos a finales de siglo llevan a pensar en una organización de este tipo 
CUADRO III

\begin{tabular}{|c|c|c|c|c|c|c|c|c|c|c|c|c|c|c|}
\hline NOMBRE DHI ABASTECHDOH & 1478 & 1479 & 1480 & 1482 & 1484 & 1485 & 1487 & 1488 & 1490 & 1492 & 1494 & 1495 & 1496 & 1497 \\
\hline Juan de Almendras & $x$ & $x$ & $x$ & & & & & & & & & $x$ & & \\
\hline Pedro de Almendras & $x$ & $x$ & & & & $x$ & $x$ & $x$ & $x$ & & & $x$ & & \\
\hline Pedro Calvo & & & & & & & & & & & & $x$ & $x$ & $x$ \\
\hline Juan Bermejo & & $x$ & & & & & & & & & & & & \\
\hline Juan Calderón & $x$ & $x$ & & & & & & & & & & & & \\
\hline Fernando de Carrión & $x$ & & & & & & & & & & & & & \\
\hline Alonso Crespo & $x$ & $x$ & $x$ & $x$ & & $x$ & $x$ & & $x$ & & & & & \\
\hline Pedro de Frias & & & $\mathrm{x}$ & & & & & & & & & & & \\
\hline Juan de Frias & & & & & & & & & & & & & $x$ & \\
\hline Pedro Garcia de la Moneda & & & & & $x$ & $x$ & & & & & & & & \\
\hline Pedro de Haro & & $x$ & & & & & & & & & & & & \\
\hline Adán de León & $x$ & $x$ & $x$ & $x$ & & $x$ & $x$ & $x$ & $x$ & $x$ & $x$ & $x$ & $x$ & $x$ \\
\hline Ferrand Martinez de Dueñas & $x$ & $x$ & $x$ & & & $x$ & $x$ & $x$ & $x$ & $\mathrm{x}$ & & $x$ & $x$ & $x$ \\
\hline Juan de Medina & & $x$ & $x$ & & & $x$ & $x$ & & & & & & & \\
\hline Miguel de León & & & & & & $x$ & & & & & & & & \\
\hline García de Matanza & & & & & & & & & & & & & $x$ & \\
\hline Diego de Oviedo & & & & & & & & & $x$ & & & & & \\
\hline Juan de Oña & $x$ & $x$ & $x$ & $x$ & & $x$ & $x$ & $x$ & $\mathrm{x}$ & & $x$ & $x$ & $x$ & $x$ \\
\hline Pedro de Oña & $x$ & $x$ & $x$ & & & $x$ & & & & & & & & \\
\hline Juan de Quiñones & & & & & & $x$ & & & $x$ & & & $x$ & & \\
\hline Pedro el Rojo & & & & & & $x$ & $x$ & & $x$ & & & $x$ & & \\
\hline Alfonso de Rueda & & & & & & & & & & & & & $x$ & \\
\hline Martin de S. Esteban & $x$ & & & & & & & & & & & & & \\
\hline Juan Revuelta & & & & & & & & & & & & & $x$ & \\
\hline Juan de Sedano & & & $x$ & & & & & & & & & & & \\
\hline
\end{tabular}


Abastecimiento urbano, mercado local y control municipal: ...

nos, habria que deducir que, al igual que ocurre en otras ciudades castellanas, se está produciendo un proceso de diferenciación en el seno de este sector de la alimentación entre abastecedores, carniceros-comerciantes y asalariados ${ }^{126}$.

\section{D) Contratos de abastecimiento y legislación complementaria}

Los contratos suscritos por los carniceros $u$ otras personas contienen las condiciones con que debe ser realizado el abastecimiento. Sus componentes no se diferencian excesivamente de los que se encuentran en otros lugares, ofrecen una notable regularidad a lo largo de todo el siglo en sus partes más sustanciales y, en esencia, son siempre los mismos. Tales condiciones serán reforzadas, a su vez, por algunas leyes concejiles que se promulgan de forma periódica, orientadas a canalizar la actuación de los carniceros -evitando abusos o haciendo respetar sus derechos- $y$, en último término, a promover la defensa del consumidor.

Los elementos que encontramos en un contrato son los siguientes ${ }^{127}$ :

1. Obligación de dar abasto de carne, vaca y carnero por excelencia, estableciéndose a lo largo del contrato si se ofertará otro tipo de ganado (oveja, cabrón. corderos, etc...).

2. Asignación de las carnicerias que deben ser abastecidas, determinando, en su caso, el número de tablas por carniceria, y, en ocasiones, la cantidad de cabezas que deben ser vendidas como minimo en cada banco.

3. Se estipula igualmente el periodo de duración del contrato.

4. Determinación de los umbrales de precios de la vaca y carnero, utilizando como unidad de medida la cuarta. Este es el componente fundamental de los compromisos suscritos, en torno al cual han girado todos los debates con las autoridades municipales. Los pre-

\footnotetext{
${ }^{126}$ Aguade, S., y Cabañas, M. ${ }^{a}$ D., "Comercio y sociedad...", págs. 503, 511 y 516 . Lo que ya no está tan claro es su vinculación a las grandes familias del Patriciado aunque, por lo que ocurre en otros lugares, asi podria ser. Sin embargo, los nombres de estos carniceros no son muy conocidos entre las grandes familias burgalesas. En cualquier caso, seria necesario hacer un estudio prosopográfico completo y profundizar más aún en el estudio del siglo xv burgalés, sobre todo de su segunda mitad.

${ }^{127}$ Habida cuenta del número relativamente importante de contratos de obligación que conocemos eliminaré, salvo en casos más puntuales, el aparato erudito. Remito, en general, a las Actas Municipales del siglo xv.
} 
cios pueden ser fijos para todo el tiempo del contrato, o variables según diversas épocas del año. Tanto el volumen de abasto, como la venta de cabezas y menudos de los carneros y los precios de la carne experimentan oscilaciones anuales coincidentes con el ritmo estacional, el ciclo de pastoreo de los ganados y los periodos religiosos. El momento de fractura se situa el 1 de noviembre (Festividad de Todos los Santos) o en Navidad y Año Nuevo, es decir, durante el periodo invernal. Por lo general, y con las lógicas excepciones, se observa que, a partir de esas fechas, los precios suben, las cantidades exigidas disminuyen y se permite pesar con el carnero la cabeza y algún otro menudo.

Si en el convenio se estipulan precios para otras reses se toman como referencia los que se han establecido para la vaca y el carnero. Así, ovejas, corderos, cabras y cabrones se ponen al precio de la vaca. Por el contrario, las terneras y los lomos de las reses vacunas se valoran como el carnero. Además, los lomos deben ser vendidos a peso y nunca a ojo. Son estos últimos dos tipos de carne que se incluyen en los contratos con mucha frecuencia durante la segunda parte del siglo, con fórmulas bastante similares ${ }^{128}$. De vez en cuando tambièn se fija el precio de las turmas (criadillas) de los carneros cojudos.

Éste y el primero son elementos que se hallan estrechamente relacionados; ambos son los componentes fundamentales del concierto establecido, en función de las líneas de actuación establecidas por la politica comercial del Concejo: alcanzar un abastecimiento abundante o suficiente y mantener los precios en niveles asequibles.

5. Se fijan las condiciones de comercialización de las diferentes partes de los animales muertos, regulándose la venta de cabezas y menudos. Este aspecto adquiere una especial regularidad en los decenios finales del Cuatrocientos. Como norma habitual, se permite pesar, con la vaca, los «mentales», lengua, y «rizos» de la cabeza, los lomos internos y riñones, pero no otro menudo alguno.

128 Por citar algunos ejemplos, en 1484: “que los lomos de las dichas vacas no se vendan a ojo saluo a peso e al precio del carnero" (AMB, Actas, 1484, fol. 26). En 1485: "podamos vender e vendamos las terneras que de nuestros ganados se ovieren que se trayeren para matar a la çibdad e los lomos que se sacaren de las dichas bacas al peso, al preçio del carnero, e no a ojo ni en otra manera alguna" (/dem, 1485, fol. 14'). En 1490: "con condiçión que las terneras de sus ganados e de las que compraren fuera de las çinco leguas e los lomos de las vacas lo puedan pesar e pesen a peso de carnero en todo el dicho tiempo" (/dem, 1490, fol. 153'), etc.. 
Abastecimiento urbano, mercado local y control municipal: ...

Con el carnero, por el contrario, no se puede pesar cabeza, lengua, hígado, corazón, riñones ni otra entraña o asadura, "salvo la canal del dicho carnero linpia, cortando la cabeça junto con el tuétano" ${ }^{129}$. En el último caso se hacen excepciones con la cabeza e higado en el segundo periodo del contrato (desde los Santos o Navidad), o en las visperas y fiestas de Navidad, Pascua Florida y Pascua de Resurrección, fechas en que si es permitida su venta ${ }^{130}$.

6. Se establecen, a la par, algunos otros compromisos. Por ejemplo, los carneros cojudos sólo pueden ser sacrificados entre Pascua de Resurrección y el dia de San Juan. A partir de esa fecha, su muerte está totalmente prohibida, pudiéndose matar únicamente carneros castrados ${ }^{131}$. Del mismo modo, es una norma muy reiterada en los contratos el compromiso de los obligados de "correr las vacas» durante una época determinada del año - desde Cincuesma (Pascua de Pentescostés) hasta el día de San Miguel de septiembre-, en dias concretos de la semana -miércoles y sábados-, y a lo largo de un circuito urbano establecido en torno a la zona del Mercado Menor.

Es menos frecuente que se determinen otras disposiciones como la prohibición de mercar carne en un entorno de cinco leguas ${ }^{132}$, o la de no pesar vaca en el banco del carnero y viceversa ${ }^{133}$.

7. Son muchas las ocasiones en que se incluye en los contratos la regulación del monopolio de la carne, prohibiendo a cualquier otra persona la matanza y venta del producto en los bancos contratados o, cuando menos, supeditando tales actividades a la licencia de los obligados.

129 AMB, Actas, 1485, fol. 14'. O "hasta la nuez del cogote" según expresión de 1461 (Idem, 1461, fol. 44). Se trata de una práctica corriente en muchos lugares (ARGENTE DEL CASTHLO, C., La ganaderia medieval..., pág. 266).

136) En 1465, la exención es explicita y alude principalmente a la negativa incidencia que tiene sobre el consumidor: "...con que podamos pesar e pesemos las cabeças de los dichos carneros e los fígados, con que al que diéremos cabeça por contrapeso le non demos fígado e al que diéremos figado le no daremos cabeça, ni pesaremos más de una cabeça de cada carnero e que repartiremos las dichas cabeças e figados lo mejor que podremos en los dichos pesos, porque la gente común sea lo más releuada que ser pudiese ser" (AMB, Actas, 1465, fols. 51-51').

131. Al igual que en Alba de Tormes y otros lugares, debido a la creencia, según J. M." Monsalvo, de que ello era un agente de enfermedad (El sistema politico..., pág. 468, n. 89).

132 AMB, Actas, 1450 , fol. 42'.

${ }^{133}$ Con el fin de evitar fraudes (AMB. Actas, 1478, fol. 59'). 
8. En todos los contratos se fijan las garantias dadas por los firmantes -carniceros obligados y Concejo-y las penas por incumplimiento de contrato.

Simultáneamente la autoridad concejil emite, haciendo uso de su capacidad normativa, una legislación complementaria que a veces reincide en algunos de estos aspectos ${ }^{134}$, y que, en general, tiende a regular los derechos y responsabilidades de los carniceros, asi como las normas con que deben ser ofrecidos los productos al público consumidor. Cuestiones que afectan, como se vió, a la circulación de las mercancias ${ }^{135}, y$, por supuesto, a su venta. Dos asuntos parecen centrar los desvelos de los oficiales: la intervención sobre la calidad del producto y el control sobre la utilización de pesos y medidas. La prevención de la calidad de la mercancia se une frecuentemente a una preocupación por la higiene. Se ha observado que una de las motivaciones centrales de los traslados de las instalaciones de carniceria fue concretamente la salubridad y prestancia de la ciudad. Calidad y limpieza son requisitos que el Concejo procura regular. Se obligó a los carniceros a cortar las piezas según un orden establecido ${ }^{136}$, a no tener las cabezas ni las asaduras del ganado muerto en los mismos bancos donde se realizaba el pesaje y la venta de las piezas ${ }^{137}$, a limpiar los suelos después de matar y desollar ${ }^{136}$, a no ensuciar las calles ni los ríos con la sangre, tripas, panzas y despojos del ganado sacrificado ${ }^{139}$, a tener los perros atados, sin que hicieran mal a nadie ${ }^{140}$, a no hinchar artificialmente la carne ${ }^{141}$, etc. Es muy riguroso, igualmente, el control establecido por el municipio sobre las pesas utilizadas, una atribución genuinamente caracteristica de los Concejos medievales ${ }^{142}$. En Burgos se emplea como unidad de peso la "Cuarta", equivalente a 42,5 onzas, y la "media cuarta» ${ }^{43}$. Con el fin de evitar irre-

${ }^{134}$ Como la obligación de correr las vacas (AMB, Actas, 1462, fol. 99'); no pesar con los carneros cabeza, higado ni pulmón (Idem, 1441, fol. 38; Idem, 1485, fol. 10); vender o no carneros cojudos (/dem, 1458, fol. $\left.71^{\prime}\right)$, o la prohibición de expender en lugares no públicos (ldem, 1476, fol. 60)

${ }^{135}$ Vid. págs. 104 y ss.

136 AMB, Actas, 1453, fol. 53.

133 AMB, Actas, 1430, fol. 104. Idem, 1481, fol. 43

${ }^{138}$ AMB. Actas, 1453 , fol 56

139 AMB, Actas, 1493, fol. 99'; Idem, 1496, fols. 102 y 164; Idem, 1497, fol. 64

14. AMB, Actas, 1480 , fol 62.

${ }_{141}$ AGS, Cámara-Pueblos, leg. 4, fol. 116 (Burgos, 1476-I-20).

142 VV. AA., Bizcaya..., págs. $341-344$

${ }^{143}$ Según aparece establecido en el contrato suscrito por seis carniceros en 1463 (AMB, Actas. 1463 , fol. 63). Aunque no significa que ésta fuera la equivalencia que existió a lo largo de toda la centuria. En 1488-1489, por ejemplo, se hicieron nuevas pesas de carniceros, obra 
gularidades y fraudes, las medidas utilizadas por los carniceros debian ser contrastadas con los pesos-patrón de la ciudad, custodiados en la Cámara de los fieles, y marcadas con el sello de Burgos ${ }^{144}$.

Otros controles del Concejo atañen a la venta de ganado vivo en el Sarmental -venta libre "a jerqueria"- y a la participación y limitaciones impuestas en este mercado a los carniceros, con el propósito primordial de entorpecer cualquier actividad que propiciara la reventa y el alza de precios ${ }^{145}$; al horario de trabajo: los bancos deben estar abastecidos desde la mañana a la noche ${ }^{146}$; y a los dias de matanza y venta, actividades en las que repercutian motivaciones de variada indole religiosa, climática y económica ${ }^{14}$.

Con el fin de promover el correcto cumplimiento de la normativa municipal y evitar la comisión de abusos y fraudes ${ }^{148}$, el Concejo habilitó los cauces pertinentes de vigilancia y castigo de los infractores. Cuando la ocasión lo requeria, se producia la supervisión directa del funcionamiento de las carnicerías por parte de los cficiales concejiles. Su intervención se observa principalmente en materia de abasto, quebrantamiento de precios $y$, en menor medida, control de la calidad de los productos ${ }^{149}$. Junto a esa actuación inmediata de la autoridad, el Concejo se ha dotado de una infraestructura de oficios estrictamente reglamentados y vinculados a las

que fue controlada por los propios oficiales del Concejo (AMB, Actas, 1488, fol. 189). Por otra parte, las pesas de Burgos eran distintas a las de otros lugares, lo cual tampoco es ninguna originalidad. Asi, y tal como se asegura en un contrato de 1483, la pesa de Valladolid y Aranda era menor que la de nuestra ciudad. Io cual deberia ser tenido en cuenta a la hora de fijar los precios si la operación se hacia con referencia a los que estuvieran vigentes en tales villas (AMB, Actas, 1483, fols. 37-37'). Vid., sobre todas estas cuestiones, KULA, W., Las medidas y los hombres. Madrid, 1980

${ }_{144}$ AMB, Actas, 1458 , fols. 44',60' y 63'. Idem. 1488, fol. 189.

${ }_{145}$ AMB, Actas, 1439 . fol. 23 ; Idem, 1445, fol. 12; Idem, 1461, fol. 40 ; Idem, 1476, fol. 24 ' Idem, 1478 , fol. 27

${ }^{146}$ AMB, Actas, 1485, fol. 14

${ }^{14 /}$ En el primer caso ya se señala en muchos contratos que las tablas deben estar abastecidas los "dias de carne". En este sentido incidirian negativamente los dias de abstinencia y, sobre todo, el periodo cuaresmal -el dia de Carnestolendas abre siempre un paréntesis en el consumo de carne por la población-, pero no, por ejemplo, el descanso dominical (AMB, Actas, 1441, fol. 25). En el siguiente aspecto, ya se ha observado la incidencia del invierno o la época de regeneración primaveral de los pastos en la minoración de las exigencias de venta de carnero. En lo que concierne a las motivaciones económicas, hablamos en su momento de la repercusión que pudo tener la presencia del mercado franco en Burgos en las actividades carniceras de los sábados (Vid. pág. 109).

${ }_{148}$ Precisamente eso fue lo que condujo a la regulación y vedamiento de participación de los oficiales en las tareas de avituallamiento de la carne.

${ }_{149}$ AMB, Actas, 1458, fols. 2 y 11 , en lo que se refiere al control de la obligación de abasto de las tablas; Idem, 1450, fol. 101, sobre desvio de precios; /dem, 1458, fol. 87 y otros, sobre la calidad de las carnes. 
actividades del comercio interior: son los "fieles de los cuatro". Custodios de su propia cámara, donde se reúnen y guardan las pesas y medidas reglamentarias que los comerciantes debian confrontar con las suyas, su cometido consiste, en general, en velar por el buen funcionamiento y justo orden del mercado urbano. Su intervención sobre las carnicerías se precisa en la vigilancia de venta de las partes prohibidas de los animales (cabezas, corazón, higado...) ${ }^{150}$ y, sobre todo, en la corrección de las infracciones de pesos y medidas ${ }^{151}$ : en algun momento se llega a disponer que los fieles "no ayan que ver sobre los carniceros salvo en el peso" ${ }^{152}$. Las penas que recaen sobre los infractores - aparte de las que derivan de los derechos de los fieles por su actuación ${ }^{153}$ _ son variadas, en función del delito cometido: pecuniarias, azotes, privación del oficio, expulsión de la ciudad o prohibición de uso de los pastos municipales.

Es precisamente éste, en compañía del monopolio de venta, el más importante privilegio que disfrutan los encargados de las carnicerias. Junto a la disposición de todo un amplio conjunto de deberes, los obligados gozaron de un tratamiento de favor en una cuestión tan crucial como el pasto de sus ganados. La normativa municipal acostumbró a garantizar el alimento de los animales destinados a los bancos de carniceria, permitiendo el uso de los ejidos, prados y pastos municipales, una práctica que tampoco en este caso es exclusiva del Concejo burgalés ${ }^{154}$. Sin ese servicio era dificil encontrar personas que aceptasen responsabilizarse de las carnicerias y su aprovisionamiento. Un privilegio de esta indole permitía abaratar los costes del mantenimiento de las reses adquiridas para el avituallamiento e impedir elevaciones de precios por este motivo, con lo cual tambièn se beneficiaba, indirectamente, al consumidor ${ }^{155}$. Asi, ya en 1411, se ordena que los carniceros de la ciudad entren, pazcan y anden con sus ganados por los pastos y ejidos que hay alrededor de la ciudad, más aún al estarse produciendo ciertas usurpaciones y abusos por los lugares y granjas comarcanos ${ }^{156}$. En 1490, al tener lugar ciertos

150 AMB, Actas, 1480 , fol. 41 ; Idem, 1490, fol. 164; ldem, 1497, fol. 86

151 AMB, Actas, 1453, fol. 37; Idem, 1490, fol. 163.

15. AMB, Actas, 1447, fol. 101'

:5.3 $48 \mathrm{mrs}$. por mal peso y $4 \mathrm{mrs}$. por venta de cabeza e higado, según un testimonio de 1453 (AMB, Actas, 1453, fol, 101').

154 Argente del Castillo, C., La ganaderia medieval..., pág. 271. Aguade, S., y Cabañas, M." D., Comercio y sociedad..., págs. 512-3. Marin Garcia, M. A. A., Las carnicerías y el abastecimiento..., pág. 78. Martin CEA, J. C., El mundo rural..., pág. 317. Bennassar, B., Valladolid en el Siglo de oro..., págs. 58 y ss. de Santos Canalejo, E. C., La historia medieval..., pág. 342, etc, etc...

iś Casado Alonso, H., Señores, mercaderes..., pág. 223

156 AMB, Actas, 1411, fol. 28. 
Abastecimiento urbano, mercado local y control municipal: ...

problemas de abastecimiento con los carniceros e implicarse las vecindades en la búsqueda de nuevos abastecedores, solicitaron éstas que los antiguos obligados expulsaran todos sus ganados, mayores y menores, fuera de los términos de Burgos, dejando los pastos libres y desembargados para los rebaños de los nuevos responsables de la carne ${ }^{157}$. Por otro lado, los carniceros burgaleses, necesitados de pastizales para sus animales, aparecieron con gran frecuencia al frente de sus manadas por los términos de Lara y su Tierra, jurisdicción dependiente del señorio burgalés ${ }^{158}$.

Podia ocurrir, y era lo más normal, que estas autorizaciones no estuvieran incluidas en las cartas de contratación o en las condiciones de los arrendamientos de las carnicerias ${ }^{159}$, pero el Concejo acostumbró a regular su concesión mediante posteriores acuerdos con los "obligados". Inevitablemente hubo abusos de los carniceros, al introducir cabezas de ganado en exceso o al permitir su entrada en las tierras cerealisticas y viñedos, y provocar con ello cuantiosos daños ${ }^{160}$. Las autoridades del municipio tuvieron que esforzarse para evitar estos delitos. Pero también tuvieron que actuar para proteger los rebaños de los carniceros de la competencia de pastos de ganaderos foráneos que, sin permiso alguno, utilizaban los términos burgaleses para alimentar sus animales. Medidas como la de 1465, ordenando acotar el soto y dehesa de Castañares "salvo para los carniçeros que basteçieran las carneçerias de la çibdad" fueron muy necesarias ${ }^{161}$.

La legislación concejil orientó su actuación en este terreno en tres sentidos. En primer lugar regulando la presencia de rebaños foráneos. En mayo de 1411 los oficiales ordenaron a los fieles de los términos de la ciudad que todos los ganados de personas de fuera, "salvo de los carniceros", que se encontraren en los términos y ejidos de la ciudad fueran prendidos y degollados. Unos meses más tarde, en septiembre, otorgaron poder a seis carniceros, vecinos de Burgos, para vigilar los pastos de la ciudad e impedir "que no entren a paçer, rozar ni cortar las personas comarcanas de los lugares de enderredor de Burgos", pudiendo prender

157 AMB, Actas, 1490, tol. 133.

158 Bonachia, J. A., El señorio de Burgos..., págs. 274-5.

159 Salvo en las de 1436 (AMB, Actas, 1436, fols. 14' y ss.).

${ }^{160}$ Ordenanza para los fieles de los términos, el vino y el pan acerca de los ganados de los carniceros: si les hallan haciendo daño en pan o en vino, tratándose de rebaños superiores a las 100 cabezas, paguen $6 \mathrm{mrs}$. si es de dia y $12 \mathrm{mrs}$. de noche. más el coste del daño, con el doblo, al dueño de los sembrados (AMB Actas, 1427, fol. 123).

161 AMB, Actas, 1465, fol. 53'. 
y degollar sus reses, de dia y de noche, si contravenian el mandato ${ }^{162}$. En 1490 los vecinos y moradores de Cortes solicitaron que les fuera reexpedido un documento extraviado según el cual los habitantes de esa aldea $y$ de Burgos tenian derecho a meter en un prado acotado sus ganados de labor, así como los carniceros sus vacas de matar, pero señalando claramente que «no entrasen dentro otros ganados ningunos... ${ }^{163}$.

El segundo campo de actuación se orientó hacia la contingentación del número de cabezas, es decir, la limitación cuantitativa de los derechos de pasto de otros ganaderos con el fin de reservar los espacios de pastizal para cubrir las necesidades de los animales de los carniceros. En 1431, hubo una protesta de los carniceros quejándose de que los vecinos de Villimar, Cortes y Villatoro traian ganados excesivos por los términos de Burgos de tal forma que ellos «no abian dónde apaçentar los ganados que tenían para el basteçimiento de la dicha çibdat». La decisión final de las autoridades consistió en limitar a 100 las cabezas de ovejas, corderos y carneros que los vecinos de tales barrios podian llevar por los términos de Burgos, siempre que, además, fueran de su propiedad ${ }^{164}$. En 1458 , la cantidad ha sido disminuida a 60 cabezas. A finales de siglo, ese es el número máximo de reses que se permite traer, salvo en el caso de que se reúnan en un mismo rebaño, conducido por un solo pastor, los animales de dos propietarios, pudiéndose llegar entonces a la suma de 90 unidades ${ }^{165}$.

Por último, el Concejo desarrollará, como ocurre en muchisimos otros núcleos castellanos, una ardua e infructuosa lucha contra la roturación de tierras baldias. Una política en la que los carniceros participaron de forma muy activa, procurando presionar en favor de sus derechos e intereses. Pero lo cierto es que, a fines del $x v$, la comarca burgalesa ha sufrido una intensa explotación y el proceso roturador continúa avanzando ${ }^{166}$. Los motivos de preocupación del Concejo son indiscutibles: la escasez de tierras de pastizal incide negativamente en las posibilidades de encontrar carniceros que se comprometan a avituallar la urbe y, por supuesto, repercuten en el encarecimiento del consumo. La situación, en la primera mitad del Quinientos, era ya extremadamente dificil; como se señalaba a

AMB, Actas, 1411, fols. 14 y 28

${ }_{163}$ AMB, Actas, 1490, fol. 137

${ }^{164}$ AMB, Actas, 1431, fol. 6. En 1436, poco después de que Juan Sánchez de Estrada firmara su contrato de obligación con la ciudad, los oficiales autorizaron a los procuradores y al propio obligado para que pudieran tomar prendas a cualquier persona que trajera por el término de la ciudad más ganados de los permitidos por la Ordenanza (Idem, 1436, F 38 ').

AMB, Actas, 1480, fols. 5, 43 y 47. Idem, 1488, fol. 157.

${ }^{166}$ Casado Alonso, H., Señores, mercaderes.., págs. 224 227. 
Abastecimiento urbano, mercado local y control municipal: ...

comienzos de 1536, «la çibdad tenía muy pocos ganados e pastos para ellos, e a esta causa en cada un año se tenía mucha fatiga en buscar carniçeros e personas que se obliguen a dar abasto de carnes en esta dicha çibdad, y demás de no se hallar en el cuerpo della ni de fuera parte quienes se quieran obligar a ello", si se hallaban, era con condicion de pagar "por quarta tres maravedís más que vale en los pueblos de la comarca de la dicha çibdad" 167.

\section{LA REGULACIÓN MUNICIPAL DE LOS PRECIOS}

El Concejo fija los precios máximos de venta de los productos o regula los mecanismos de determinación de las tasas. Al precio de las carnes se llega por varios caminos:

a) Mediante imposición del Concejo, a través de las disposiciones y el ordenamiento regular cotidiano, siempre que no se consiga llegar a un acuerdo previo con los carniceros y abastecedores. Este recurso, puesto en práctica con bastante frecuencia, se observa con mayor intensidad durante los primeros decenios del periodo estudiado, mientras aún no se encuentra plenamente definido el sistema de obligados, $y$, sobre todo, en los años en que no se cubren o se tardan en cubrir las necesidades de abastecimiento, principalmente en los periodos de inestabilidad politica y monetaria.

b) Mediante las pujas, en los momentos en que el avituallamiento de carne es decidido en almoneda pública. El remate de la subasta se otorga al licitador que ofrece precios más bajos al consumo. Es, pues, la competencia entre diversos subastadores la que fija unos precios que se deciden a la baja. Eso significa, igualmente, que obtiene el remate el individuo que conseguirá menores márgenes de ganancia. Por lo tanto, y habida cuenta del desequilibrio que se establece entre abastecimiento-precios-ganancia del comerciante, no extraña que existan años en que los pregones no obtienen ninguna respuesta ${ }^{168}$.

167 Hernandez Esteve, E., Noticia del abastecimiento..., pág. 9.

is El año 1441 ofrece problemas de dificil solución a las autoridades del Concejo. No se encuentran proveedores de ninguna forma. En un momento determinado en que algunas vecindades solicitan que las carnicerias se pongan en subasta - ya que "alguno saldria que se obligaria abasteçer la ciudad de carne»-, los oficiales responden que hacia ya cuatro o cinco meses que se habian lanzado pregones y nadie habia venido a poner precios (AMB, Actas, 1441, fol. 25). 
c) Tras convenio entre el Concejo y los carniceros que se interesan por realizar el abastecimiento. En las últimas décadas del siglo XV se ha logrado, incluso, una cierta ordenación del proceso de fijación de los precios en situaciones concretas. Cuando los contratos se firman por dos años o más, se señalan las tasas del primer año y se designan compromisarios encargados de determinarlas en el futuro, «según la abundancia o esterilidad de los años venideros" "169. Tanto en este caso como en el anterior, los precios subastados, acordados o, en la peor de las situaciones, impuestos, son condición elemental de los contratos.

La finalidad de esa politica de precios máximos y asequibles que sigue el Concejo de Burgos es la misma que imbuye, en todo momento, la perseguida y puesta en práctica por otros municipios medievales castellanos y europeos: se trata de tener alimentos bastantes pero también baratos, al alcance de las más amplias masas del vecindario urbano. En definitiva, como se ha dicho ${ }^{170}$, la tasación de precios es una garantía de paz social. La resolución de las necesidades alimenticias de la población, asi como de sus problemas sanitarios y de salubridad, se engloban en una politica del patriciado urbano de control social, traducida en un amplio conjunto de medidas tendentes a reducir en lo posible los riesgos politicos y sociales latentes en un medio urbano permanentemente expuesto a la carestia, la escasez, el hambre o las epidemias. En relación con esos objetivos de orden social, cobertura de las necesidades de alimentación y estabilidad de los precios, es donde hay que ubicar otras prácticas, contradictorias por definición ya que contradictorios son los objetivos perseguidos y los intereses representados, como la regulación de la reventa: una reglamentación que está inmersa en un debate permanente por encontrar el equilibrio entre, por un lado, los negativos efectos

${ }^{169}$ Por ejemplo, en 1492, Adán de León y Ferrand Martinez de Dueñas han obtenido el abastecimiento para los dos años que se extienden entre San Juan de 1492 y San Juan de 1494. A punto de finalizarse el primer periodo, el 17 de junio de 1493, se reúnen Pedro Orense, como representante del Concejo, y el carnicero Adán, y determinan los precios que regirán durante el segundo año (AMB, Actas, 1493, fol. 56'). En cualquier caso, este sistema tarnpoco es una garantía segura de acuerdo y abasto. Alonso Crespo, Juan de Oña y Adán de León se obligaron para el periodo 1482-1485. Cuando debieron acordar con el regimiento los precios para el ejercicio 1483-1484, fue éste último quien, en el último momento, acabó imponiendo unos umbrales de precios, mientras que a la vez, y por la persistente falta de acuerdo, ambas partes acabaron considerando nulo el contrato para el último año, quedando, en consecuencia, libre el acceso a las carnicerias para cualquier otro interesado (AMB, Actas, 1483, fols. 37-37'y 57)

${ }^{170}$ Bafel, Y., La ciudad medieval. Sistema social-Sistema urbano. Madrid 1981, págs. 241 y ss. 
de la regatonería - acaparación, desabastecimiento, origen de tensiones inflacionistas- $y$, por otro, la necesidad que se tiene de ella como mecanismo ocasional de regulación del mercado. O que se contempla, del mismo modo, en la defensa de la capacidad productiva y autoabastecedora de los vecinos. La cría de ganado porcino es un buen indice de los delicados equilibrios que el Concejo debe sostener en multitud de ocasiones: esta vez entre las condiciones de higiene y salubridad de la urbe y la defensa de las capacidades de autoabastecimiento de un buen número de vecinos burgaleses. Las autoridades no pueden permitir que las piaras de cerdos deambulen sueltas por la ciudad, originando molestias e incrementando la suciedad de las calles, pero tampoco pueden ordenar la desaparición absoluta de este tipo de ganado, según ordena el monarca en un primer instante, puesto que, como se dice en algún momento, "muchos pobres se mantenían en los criar" ${ }^{171}$. La solución finalmente acordada, que se mantuvo a lo largo del siglo con muy leves variantes, fue su salida diaria, bajo el cuidado de un porquero, a los montes extramuros de la ciudad, y su regreso, por la tarde, en las últimas horas del día, para ser inmediatamente encerrados en las pocilgas de sus propietarios.

El Concejo ejerce una intervención determinante en el sector alimenticio y establece unos precios políticos cuyas oscilaciones están constantemente bajo su control. Ahora bien, si en la fijación de las tasas de venta participa decisivamente la política fiscalizadora del Regimiento, eso no implica que no actuen sobre ellas otros factores ajenos, de indole objetiva. En este sentido, aunque los precios medievales no están rigurosamente regidos por la ley de la oferta y la demanda, no puede olvidarse su influjo: a una oferta baja correspone una presión alcista, y al contrario. En 1481 un alcalde solicita a Juan de Oña, uno de los carniceros obligados, que se reúna con él para que entre ambos diluciden un nuevo precio de la carne, puesto que "segund la muchedumbre de las carnes es razón que se abaxe e ponga en razonable preçio». En el extremo contrario, los "fortunosos" tiempos que han corrido durante los años anteriores han provocado escasez de carnes en 1486 y ello dió lugar a que los oficiales

${ }^{17}$ AMB, Actas, 1429, fol. 73'. En 1495, se prorroga el plazo de matanza de los cerdos más allá del dia de San Martin, debido a las adversas condiciones climáticas existentes — "hasta aqui no ha hecho invierno salvo tiempo humido e caluroso e no ha avido disposición de matar los puercos»- y la solicitud se hace por compasión hacia los pobres «por que no se pierdan» (AGS. Cámara-Pueblos, leg. 4, fol. 100). Esta circunstancia y la abundancia de propietarios de ganado porcino en Burgos dio lugar a que la Ordenanza municipa fuera frecuentemente incumplida. Las cabezas que anduvieran por la ciudad durante el dia podian ser matadas por cualquier persona que las encontrara. Sin embargo, en 1480, se asegura que esta pena no se ejecutaba debido a la solidaridad manifestada entre los vecinos, "por no hacer daño uno a otro" (AMB, Actas, 1480, fol. 53"). 
discutieran y finalmente decidieran pujar los precios a los proveedores ${ }^{172}$. Del mismo modo, también debe influir el valor de compra del producto. al cual habria que añadir los costes de transporte, gastos fiscales, de manutención, alojamiento y salario de los agentes y pastores encargados de la compra y del traslado del ganado, etc.. ${ }^{173}$. Por eso son frecuentes las peticiones de información realizadas por las autoridades acerca de los precios vigentes en otros lugares. En 1445, por ejemplo, se enviaron mensajeros a Medina del Campo para conocer los precios de la carne ${ }^{174}$; y en 1493, por citar otro caso, acordaron enviar a saber cuál era el valor de la mercancía en Zamora, Ávila, Medina, Salamanca y Palencia ${ }^{175}$.

Además, el Concejo debe compatibilizar el objetivo prioritario de defensa del consumidor con otros intereses contrapuestos que también repercuten en la decisión que se tome sobre el precio final. Por una parte, están los que conciernen a los comerciantes, que se traducen en la necesidad de encontrar unos márgenes de "ganancia razonable". La inevitable discusión que se sucede año tras año, entre los carniceros y el Concejo, en torno a los precios, es un índice ilustrativo, tanto de la relevancia que juega este factor en la estipulación definitiva de los umbrales máximos de venta, como de la persistente presión ejercida por los proveedores sobre la administración municipal. Al fin y al cabo un acuerdo definitivo sobre los precios implica la consecución de un más que previsible seguro de abastecimiento urbano. Por el contrario, la ausencia de una decisión final incidirá, salvo que se habiliten otros recursos más costosos para la ciudad, en la escasez del artículo en el mercado ${ }^{176}$.

El esfuerzo del Concejo se debia orientar a conciliar los beneficios de los expendedores con la tasación de precios máximos, teniendo siempre como horizonte último el objetivo de no descuidar la provisión urbana y la alimentación del ciudadano. En último término, pues, el oficio de carnicero es considerado por la administración municipal tanto más un ser-

${ }^{172}$ En arnbos casos, como se desprende del Cuadro IV, se produce, respectivamente, el descenso o el alza de los precios (AMB, Actas, 1481, fol. 32'. Idem, 1486, fols. 22 y 26).

$1 / 3$ Hernandez Esteve, E., Noticia del abastecimiento.., págs. 25 y ss.

'1/4 AMB, Actas, 1445, fols. 23 y 31'.

17 AMB, Actas, 1493, fol. 48.

${ }^{1 / 6}$ En 1429, los procuradores de la ciudad apremiaban a los oficiales para que decidieran la torma de realizar el avituallamiento, de manera que «si entendian ponerlo al almoneda que lo pusiesen, e si entendian ordenar algo sobre ello que lo ordenasen luego, porque la çibdad fuese basteçida de carne e no obiese falta" (AMB, Actas, 1429, fol. 25). En 1447 discutian sobre la escasez de carne que habia en Burgos porque nadie queria tomar las carnicerias de la ciudad para abastecerlas; y observan que, si no se llegaba a un acuerdo. habia peligro de que la ciudad estuviera sin carne (Idem, 1447, fs. 101 y 105). En 1461. constataban que la falta de carniceros repercutia en las dificultades de abastecimiento que estaba atravesando la urbe (/dem, 1461, fol. 36). 
vicio público que una empresa lucrativa. El bien colectivo adquiere primacia sobre el provecho particular del abastecedor; las ganancias deben ser justas, pero no desproporcionadas. No obstante, quien fija esos márgenes de beneficio no es el mercado ni el comerciante, sino la autoridad pública municipal que es quien decide los precios. La negativa de los proveedores a cortar y vender carne puede ser castigada, en consecuencia, con la privación del oficio y la expulsión de la ciudad. En marzo de 1411 , los oficiales municipales querian poner "precios razonables" para los tiempos del Carnal, pero los carniceros se oponian a abastecer la ciudad porque, en opinión de aquéllos, buscaban uganancias muy desaguisadas" y "sus provechos singulares". Después de un mes de debates, los comerciantes se negaron rotundamente a ofrecer la carne según el precio estipulado por el Concejo, a pesar de que la autoridad consideraba que se habian establecido tasas adecuadas y habia comprobado que "tenian en ello ganancia y lo podian bien dar". La actitud de rechazo de los abastecedores fue considerada como un perjuicio "contra la ciudad y su pueblo» y un «menosprecio de la ciudad y sus regidores». La decisión final de los oficiales fue la privación, durante dos años, a cierto número de carniceros, del oficio "de vender y tajar carne, por si ni por otro, en la ciudad, en sus carnecerias ni las de los términos" " ${ }^{177}$.

Los comerciantes se muestran permanentemente dispuestos a servir a la ciudad, pero su condición inexcusable es que se les permita obtener "Caudal y ganancia" ${ }^{178}$. A veces ocurre, como en 1411, que las posturas son irreconciliables. Hay ocasiones en que las protestas de los carniceros sobre la endeblez de los precios y las pérdidas que esto les ocasiona no tienen ningún efecto ${ }^{179}$. En otros momentos, sin embargo, su presión repercutirá en elevaciones de los precios. En noviembre de 1398 se quejaron de que, tal como estaban establecidas las tasas de venta, no podian dar abasto si no era a costa de «muy grand daño suyo». Los oficiales pujaron un 15 por 100 el precio del carnero y un 11 por 100 el de la vaca ${ }^{180}$. Semejante alza, y por idénticas razones, tuvo lugar en diciembre de 1462 con la cuarta del carnero ${ }^{181}$ En agosto de 1476, los integrantes del Regimiento se aprestaron a buscar acuerdos con los comerciantes porque «luego que sepan que pierden, como ahora ganan, dejarán de dar la carne». Efectivamente, los carniceros se negaron a abastecer si no se

AMB, Actas, 1411, fols. 3 a 20.

${ }^{178}$ AMB, Actas, 1423, fol. 126

${ }^{179}$ Como en julio de 1432 , en que los precios se sostienen según estaban establecidos en abril de ese mismo año (AMB, Actas, 1432, fol. 72).

${ }_{180}$ AMB, Actas, 1398, fol. 86

181 AMB, Actas, 1462, fol. 139' 
elevaban los precios. A la postre, ambas partes acordaron alzar $1 \mathrm{mrs}$ el del carnero ${ }^{182}$. Otro tanto ocurre en 1486 , por las pérdidas que han sufrido, debidas, en esta ocasión, a las calamidades naturales que han afectado al ganado ${ }^{183}$.

No hay que olvidar, por otro lado, que la politica comercial del Concejo se realiza también en función de los intereses fiscales que afectan a la Hacienda municipal. Como ya indiqué al comienzo de este trabajo, la ciudad interviene indirectamente en los beneficios originados por el comercio de la carne, a través de los censos percibidos de los explotadores de los bancos; participa iguaimente en ellos mediante los derechos que recaen sobre la utilización de los pesos y medidas oficiales; pero también genera renta a través de las cargas fiscales con que se gravan las transacciones. Como muy acertadamente se ha apuntado, hay una explotación del comercio basada en las detracciones fiscales realizadas sobre el proceso mercantil o sobre los agentes del mismo ${ }^{184}$.

Los "derechos o rentas de las carnes", gravamen especifico que recae sobre la comercialización de este artículo en el mercado urbano, es uno de los componentes de las "Rentas de Barra y Portazgo", es decir del recurso tributario de mayor envergadura de la ciudad y sobre el que reposa toda la organización de las finanzas municipales. En ocasiones son los propios obligados quienes, junto al abastecimiento de las tablas, arriendan igualmente los derechos de la carne de la Hacienda. En 1436 , Juan Sánchez de Estrada se comprometia a pagar al mayordomo del Concejo la renta de la carne muerta de 1437, 1438 y 1439 a razón de 75.000 mrs. por año. En todo caso, sea cual fuere la forma de gestionar este recurso fiscaí, lo cierto es, como señala J. A. Pardos, que un sector muy importante del consumo resultaba mediatizado por la Hacienda concejil ${ }^{185}$. También afectó al mercado de la carne la imposición de sisas. Este impuesto indirecto, extraordinario en principio pero que adquirió rasgos de ordinariedad con el tiempo, recayó, como norma más usual en Burgos, sobre el vino. Durante el siglo $x v$ no fueron muy frecuentes las sisas múltiples impuestas sobre mantenimientos diversos, pero tampoco

1t:2 AMB, Actas, 1476, fols. 56' y ss.

183 AMB, Actas, 1486, fols. 22 y ss.

134 Aguade, S., y Cabañas, M. " D., "Comercio y sociedad...", pág. 507.

${ }^{185}$ Vid. Pardos Martinez, J. A., La renta de Alcabala vieja..., págs. 638-639. El dato referente a Juan Sánchez de Estrada en AMB, Actas, 1436, fols. 14' y ss. y 26-28. Hay que observar que muchos años, sobre todo en la primera mitad de siglo, las rentas de Barra y Portazgo fueron arrendadas "sin los derechos de la carne". Juan Sánchez de Estrada aparece, por ejemplo, como "arrendador de la carne", durante los años citados, al mismo tiempo que los arrendadores de las "rentas del Concejo". Sin embargo, en 1441, éstas últimas se pregonaron incluyendo ya en ellas las rentas de la carne. 
faltaron a lo largo de los años. De 1398 data una imposición sobre el consumo de carne viva, carne muerta, vino y vinagre. No obstante, hasta finales del Cuatrocientos - precisamente en el momento en que la Hacienda debe recurrir a una permanente multiplicación de sisas con el fin de respaldar la deuda municipal y tapar las brechas originadas en las arcas del fisco ${ }^{186}$ - , no volvemos a encontrar nuevas imposiciones sobre la carne. Es obvio que las sisas también tuvieron su reflejo en los precios: en 1398 supuso añadir 1 dinero en la cuarta del carnero y de la vaca ${ }^{187}$. Las condiciones de la sisa de 1494 establecian un coste de una blanca por cada cuarta de vaca o carnero y por cada libra de tocino vendidos a peso ${ }^{188}$. La misma cantidad fue la que repercutió en los precios de 1496 y 1497 al establecer una sisa que gravaba las cuartas de carnero, vaca, ternera, oveja, cordero y cabrón ${ }^{189}$. En este orden de cosas, parece indudable que el control y la centralización sobre la ubicación de los bancos de carnicería estaba motivado también por criterios de eficacia fiscal, al facilitar y simplicar a los arrendadores --aicabaleros, siseros, etc...y sus guardas la recaudación de los impuestos que gravaban las transacciones ${ }^{190}$.

Parece indiscutible que la finalidad primordial de la politica comercial del Concejo era la defensa del consumidor: le movian a ello motivaciones obvias de orden social. Pero también subyacian otros objetivos que se ajustaban a los intereses fiscales del municipio. Muchas ordenanzas y disposiciones legales emitidas por el gobierno de la ciudad para asegurar un buen abastecimiento y un control eficaz sobre las carnicerias, lo son también en función de la obtención de nuevas fuentes de ingresos - si no hay un aprovisionamiento regular las rentas quiebran - y del arbitraje de mecanismos apropiados para su percepción. En definitiva, la politica del Concejo se mueve secularmente sobre equilibrios muy precarios: entre la prohibición de una reventa especuladora e inflacionista por definición y la necesidad que se tiene de ella, en ocasiones, como elemento estabilizador del mercado urbano y mecanismo regulador de los dese-

${ }^{186}$ Sobre el recurso a la sisa en Burgos, su progresiva multiplicación y adquisición de caracteres ordinarios, su significado, etc..., PARdos, J. A., La renta de Alcabala vieja....

187 AMB, Actas, 1398, fol. 33

${ }^{188}$ AMB, Actas, 1494, fols. 212' y ss. La sisa de este año recayó sobre el trigo que se lievaba a los molinos, la harina que se vendía en el mercado, el pan cocido, el vino tinto. las carnes vivas y las carnes muertas. Por lo tanto, se estipulan las cantidades impuestas sobre las reses vendidas el dia del mercado: $5 \mathrm{mrs}$. por cada cabeza de carnero; $3 \mathrm{mrs}$. por oveja; $5 \mathrm{mrs}$. por cada cabra o cabrón; $10 \mathrm{mrs}$. por puerco; 1 real por buey o vaca; 15 mrs. por cada ternera o añojo; $3 \mathrm{mrs}$. de cada cordero o cordera extremeños.

${ }^{189}$ AMB, Actas, 1496, fol. 66. Idem, 1497, fol. 36.

${ }_{190}$ Vid. ก. 54 
quilibrios entre la oferta y la demanda; entre unos precios de tasa que no pueden ser elevados sin provocar protestas en la población y las «ganancias razonables" que hay que asegurar a los obligados si se quiere garantizar un abastecimiento suficiente; entre la defensa del poder adquisitivo de la población y una politica fiscal que, al gravar los artículos de consumo diarios y elevar el coste de la vida, repercute de forma más negativa precisamente sobre los consumidores.

Como se deduce de las Tablas de Precios del CuadrolV, las carnes que se tasan son básicamente la vaca y el carnero, es decir, aquellas que, se supone, se consumen con mayor frecuencia y abundancia. Eso no significa que no se estipulen los precios de otros animales (cordero, oveja, ternera, cabrito, cabra y cabrón), asi como los de algunas piezas concretas del ganado (turmas, tocino, lomos del vacuno). Ahora bien, esa tasación se realiza, normalmente, tomando como referencia las carnes anteriores, principalmente la de vaca. Por otro lado, ésta es siempre entre un 25 y un 40 por 100 más barata que la del carnero. Sólo la carne de las terneras y los lomos vacunos son vendidos al precio de este último animal.

En segundo lugar, los precios pueden oscilar en algunos contratos según la época del año en que se efectúe la venta. Asi, suelen descender ligeramente durante el verano hasta el inicio de los frios y la época invernal (Noviembre, Navidad), para elevarse más tarde durante todo el periodo que lleva hasta finales de la primavera y comienzos del estio. El fenómeno no habria que ponerle en relación con un aumento de la demanda por esas fechas, sino con unos mayores costes de mantenimiento soportados por el ganadero a causa de las mayores dificultades de alimentación que encuentra para sus animales: los ciclos de trashumancia, la rarificación de los pastos en invierno, la necesidad de su renovación durante los meses de primavera y la desaparición de muchas rastrojeras a partir del otoño, debido al inicio de un nuevo ciclo de cultivos, dificultan la labor de alimentación del ganado y elevan los gastos. Además también habria que tener en cuenta que la matanza del cerdo, a partir del dia de San Martír de Noviembre, introduce una fuerte competencia al resto de las carnes en el consumo familiar. Todos esos factores vendrian a explicar las variantes en las condiciones de contratación que observábamos en páginas anteriores: durante la temporada de invierno y primavera, hay unos precios más altos, una menor exigencia de la cantidad de cabezas de ganado que deben ser ofertadas por tabla o una mayor intensidad en la concesión de licencias para vender partes prohibidas de la res (cabeza e higado). Todas esas medidas se utilizan como medios de primar el compromiso de abastecimiento y la mayor inversión efectuada por el carnicero durante esos meses. 
En otros momentos, las fluctuaciones que se observan a lo largo de un año concreto se producen, no tanto por las razones climáticas y de cria del ganado arriba apuntadas, cuanto por motivaciones coyunturales de otro tipo. Tal ocurre con la incidencia desmesurada en el alza de los precios de las reformas monetarias realizadas por los monarcas y la inmediata politica de contención y disminución practicada por el Concejo. El sobresalto monetario provocado por Juan I en 1386 y 1387 con las transformaciones introducidas en el curso legal de los "blancos" se tradujo en un profundo desorden en la fijación de precios ${ }^{191}$ que, en nuestro caso concreto, tuvo su reflejo en una fortísima inflación del precio de la carne en 1388. Algo similar ocurrió en 1462. Inmediatamente después de la reforma efectuada en mayo por Enrique IV ${ }^{192}$, el precio del carnero se disparó al alza. Sin embargo, las tensiones inflacionistas originadas por las nuevas equivalencias monetarias fueron respondidas siempre por una rapidisima tendencia a la baja dirigida y provocada artificialmente por el Concejo a través de su política de tasación de precios ${ }^{193}$. Es en esos casos cuando el control del Concejo sobre los precios y su utilización politica actúa de una manera muy clara como mecanismo corrector de desequilibrios. Los fenómenos de acaparación de alimentos y elevación de precios que derivan del caos monetario alimentan inevitablemente el malestar urbano y las autoridades municipales se ven obligadas a evitar los riesgos de la inestabilidad social interna. El problema es especialmente grave si, como ocurre en 1462, las alteraciones monetarias y las tendencias alcistas coinciden con unos años - los que transcurren desde la década de los Cincuenta hasta los primeros momentos del reinado de los Reyes Católicos- en los que concurren una multitud de fenómenos (pestes, carestias, caída de las rentas municipales, presión fiscal, conflictos con el castillo, bandolerismo, luchas de bandos urbanos...) que traslucen la profunda desestabilización demográfica, económica y política por la que atraviesa el Reino, y en particular nuestra ciudad, a lo largo de esos años ${ }^{194}$.

Un somero repaso por la evolución de los precios nominales de la carne a lo largo del siglo, coincide con las apreciaciones sobre las ten-

is) Ladero Quesada, M. A., "La politica monetaria en la Corona de Castilla (1369-1497)", En la España Medieval, n."11, 1988, págs. 79-123, en concreto, pags. 88-90.

${ }^{192}$ Ladero Quesada, M. A., "Moneda y tasa de precios en 1462. Un episodio ignorado en la politica económica de Enrique IV de Castilla", El Siglo xv en Castilla: Fuentes de renta y politica fiscal. Barcelona 1982, págs. 114-142. Idem, “La política monetaria...», págs. 101-103.

${ }^{193}$ A partir de junio de 1462 , por ejemplo, se fija todo un proyecto de contención de precios dirigido por la Corona y articulado por el Concejo en el que intervendrán muy diversos protagonistas (AMB, Actas, 1462, fols. 91 y Ss.).

${ }^{194}$ Bonachia, J. A., Burgos en la Edad..., págs. 379-386. 
dencias generales de los precios y salarios expuestas por otros autores. En principio, se observa muy claramente que muestran una orientación secular al crecimiento, idéntica a la que se puede contemplar en otras localidades ${ }^{195}$, cuyas causas han sido sobredamente analizadas ${ }^{196}$. Por otro lado, también se encuentran bastante bien definidas las tres etapas que $H$. Casado ha esbozado para la coyuntura burgalesa ${ }^{197}$ :

a) Una primera fase de inflación muy débil, que se extiende desde comienzos de siglo hasta finales de los años Treinta, coincidiendo con una época de prosperidad urbana.

b) A partir de los años Cuarenta comienzan las dificultades y se inicia una etapa de fuerte alza que llega hasta comienzos del reinado de los Reyes Católicos. No son ajenas a ese proceso las continuas devaluaciones que sufre el maravedi ${ }^{198}$. Es la época de mayores presiones inflacionistas del siglo xv, constatándose una hiperinflación fortísima en los años Sesenta y Setenta, unas décadas de enorme inestabilidad en todos los niveles que, como se avanzó antes, resultan catastróficas para la ciudad ${ }^{199}$.

c) Una tercera fase, que ocupa los 25 primeros años del reinado de Fernando e Isabel, en la que los precios aparecen estabilizados, reflejando a su vez la normalización política y monetaria que se ha logrado durante el reinado.

\section{OTROS RECURSOS DE ABASTECIMIENTO}

Como hemos venido observando a lo largo de estas páginas, la búsqueda de obligados fue siempre un problema grave para el Concejo: y es que no siempre hubo personas, carniceros o no, dispuestas a encargarse del abastecimiento urbano. De nuevo surge el problema del equilibrio, muy dificil, entre el programa politico de un abastecimiento seguro y la

\footnotetext{
${ }^{195}$ Siempre refiriéndonos a los valores de las carnes. Monsalvo, J. M. ${ }^{a}$, El sistema politico..., págs. 484-486; Aguade, S. y Cabañas, M. ${ }^{a}$ D., "Comercio y sociedad...", pág. 50; M. $^{\text {" }}$ Marin Garcia, M. ${ }^{a}$ A., "Las carnicerías y el abastecimiento...", págs. 95-99.

196 Mackay, A., Money, Prices and politics in Fifteenth-Century Castile. London, 1981

197 Casado Alonso, H., Señores, mercaderes..., págs. 303-308. Idem, “La construction à Burgos à la fin du Moyen-Age. Prix et salaires", Cahiers de la Mediterranée, 31, 1985, págs. 125-149.

198 Ladero Quesada, M. A., "La política monetaria....", págs. 95 y ss.

199 Vid. PARdos, Julio A., "La renta de Alcabala vieja...".
} 
fijación de unos precios que fueran asequibles a la capacidad adquisitiva del vecindario. Año tras año se entraba en una dinámica de muy dificil solución. Da la impresión de que la tasación de precios era algo irreconciliable -o muy dificil de aunar - con las ganancias deseadas por los obligados. Los riesgos eran importantes y los beneficios escasos. Epidemias y desastres naturales ${ }^{200}$, guerras, conflictividad e inestabilidad política ${ }^{201}$, reformas de la politica monetaria de los gobernantes del reino, incidian negativamente en la actividad de unos abastecedores cuya inversión en las empresas de avituallamiento implicaba unos costes elevados. Según el minucioso y modélico estudio realizado por E. Hernández Esteve, aunque referido al año 1536-1537, habria que sumar al precio de compra del ganado los gastos derivados de la satisfacción de gravámenes fiscales (portazgos, alcabalas...), de los costes de transporte, del mantenimiento y salario de los individuos (agentes y pastores) encargados de la adquisición y conducción de las reses, asi como de las costas de las carnicerias (alquileres y censos, salarios de los tablajeros, etc.) ${ }^{202}$. No es extraño, pues, que en 1441 los «bollicios" del Reino repercutieran en la falta de licitadores al cargo; o que los cambios monetarios provocados por el monarca en 1462 afectaran gravemente a la estabilidad de los precios y a la labor de los carniceros. La variabilidad de contratos y las dificultades con las que se encuentra el Regimiento burgalés en el periodo central del siglo están en consonancia con los difíciles tiempos que atraviesa la ciudad y la falta de garantias y los consiguientes riesgos que afrontan los abastecedores en su labor.

Si los precios se abarataban, los carniceros no obtenian ganancias o éstas eran muy escasas; y si no se obtenia provecho de esta actividad, nadie o muy pocos estaban dispuestos a contratar el abastecimiento, con lo cual volvia a recorrer la ciudad el fantasma de la escasez. Bueno era que se estableciera un sistema monopolístico de mercado; pero eso sólo aseguraba la eliminación de la competencia, no la rentabilidad de un negocio sometido a unos umbrales máximos de precios ${ }^{203}$. No fue, por 10 tanto, nada infrecuente que se hiciera extremadamente complicado y difícil encontrar individuos que se obligasen a proveer la ciudad. Sólo hace

${ }^{200}$ Como los «fortunosos" tiempos de 1486 (AMB, Actas, 1486, fol. 22) o las calamidades de 1491 (Idem, 1491, fols. 36 y ss). Hernandez Esteve, E., cita el contagio y muerte, en 1536 , de una partida de carneros comprados en Tarifa (Noticia del abastecimiento..., pág. 11).

201 En 1441, los oficiales reconocen ante los procuradores de las vecindades que, "segund los bolliçios que avian en este regno", no encontrarian persona que quisiera obligarse a abastecer de carne a la ciudad (AMB, Actas, 1441, fol. 25).

${ }^{202}$ Hernández Esteve, E., , Noticia del abastecimiento..., págs. 25-48, 107 y ss.

${ }^{203}$ Gonzalez Jiménez, M., El Concejo de Carmona..., págs. 270-271. 
falta echar un rápido vistazo por las Actas municipales para obtener un vivo testimonio de una dinámica que, de forma casi inevitable, se repite ejercicio tras ejercicio.

Es posible que el sistema de obligados no fuera un seguro perfecto de abastecimiento. No son extraños los requerimientos o las protestas lanzadas hacia los carniceros para que observen sus compromisos de avituallamiento, como tampoco son infrecuentes las amenazas y las penas que se imponen por su falta de observancia ${ }^{204}$. Pero no deja de ser menos cierto que era el sistema más eficaz para procurar una satisfacción adecuada de la demanda de carne de la población urbana. $\mathrm{O}$, volviendo la oración por pasiva, si es evidente que los años contratados no ofrecen excesivos problemas, los "no obligados" se traducen automáticamente en escasez y carencia de la mercancia.

En estos casos el Concejo tuvo que recurrir a otros medios de abastecimiento para solventar o paliar cuando menos los efectos de la carestía. La autoridad urbana apeló, en repetidas ocasiones, a las amenazas contra los carniceros (privación del oficio, expulsión de la ciudad, anulación de los derechos de pasto...): no sirvieron de nada puesto que, una vez tras otra, los problemas vuelven a plantearse en las Actas en términos similares. Acudió también, como hemos comprobado, a la iniciativa privada, a contratos de suministro con pequeños ganaderos, a buscar abastecedores fuera de Burgos, a renovar con insistencia el recurso a la veda de compra en un entorno de cinco leguas, e, incluso, a alzar a los oficiales del Ayuntamiento la prohibición que les impedia efectuar negocios de abastecimiento. Eran remedios que, al menos, servian para tapar parcialmente las brechas originadas por un abastecimiento deficiente.

Pero no terminan ahí todos los recursos proyectados o puestos en práctica por el Concejo para atenuar sus dificultades. En abril de 1450 , debido a la gran carestía que padecia la ciudad, se propuso ofrecer libertad de mercado a todos aquellos que quisieran vender carne, ya fuera a peso o a ojo ${ }^{205}$. Otras veces, se exime de impuestos a las personas que han abastecido la ciudad en momentos críticos. En 1449-1450 varios individuos fueron liberados de la alcabala que les demandaban por los animales que habian traido a Burgos, por ruego de la ciudad, para su provisión ${ }^{206}$. Unos años después, en 1463, el Ayuntamiento efectuó diversos libramientos a favor de cinco carniceros, en concepto de devolución de la "barra» abonada por las reses vendidas en la ciudad "cuando es-

204 AMB, Actas, 1447, fol. 101'. Idem, 1478, fol. 27'. Idem, 1496, fol. 17.

aMb Actas, 1450 , fol. 48.

206 AMB, Actas, 1450, fols. 28, 32, 41: 
Abastecimiento urbano, mercado local y control municipal: ...

taba en necesidad de carne" y aún no se habian contratado obligados ${ }^{207}$ Más utilizado, aunque igualmente costoso para las finanzas municipales, fue el recurso a las subvenciones y ayudas a la importación y el abasto de carne. En 1432, los oficiales prometian a los carniceros un préstamo de $30.000 \mathrm{mrs}$. si se obligaban a tomar y proveer las carnicerías ${ }^{208}$. En 1463 pedian a los carniceros que vendieran la carne a los precios que estaban asentados, comprometiéndose a satisfacerles en el caso de que tuvieran pérdidas ${ }^{209}$. Para finalizar, en 1478 decidieron estudiar la compensación que debian otorgar a Adán de León por haber traido a Burgos 500 carneros $^{210}$. Alguna vez se llega a ordenar al "merino" que mate y haga vender las carnes si los carniceros no las quieren suministrar a los precios dispuestos ${ }^{211}$. Lo que ocurre en 1441, un año de especial carestia de carne en la ciudad, es muy expresivo. De forma sucesiva, el Concejo acudió prácticamente a todos los recursos que se han citado: puso en almoneda, sin éxito, la provisión de las carnes; subvencionó las pérdidas generadas por algunas operaciones de compra; amenazó con prisión a los comerciantes que se negaran a matar; recurrió a la adquisición de reses de propietarios privados (Condesa de Alba, Fernando Garcia Orense, Bartolomé Panero...); ordenó al merino que matara lo que fuere menester si los expendedores no daban abasto... Incluso, llegó a efectuar un repartimiento de $205.000 \mathrm{mrs}$. entre las collaciones, con el fin de financiar la compra de ganado ${ }^{212}$.

Es ésta otra medida que contemplamos en alguna ocasión: incapaz de resolver los problemas de abastecimiento con los carniceros, el Concejo involucró a las vencindades en la gestión de las carnicerias, a pesar del coste social que ello suponía. El interés que, a lo largo de todo el siglo, manifestaron las collaciones, a través de sus procuradores, por obtener un buen abastecimiento de carne, seguro y barato, es perfectamente razonable. Al cabo, ellos eran los consumidores y básicamente en función de sus intereses desarrollaban las autoridades su politica económica. Es lógico que muchas veces tuvieran una participación activa en las discusiones y que su objetivo prioritario fuera asegurar la provisión del pro-

${ }^{207}$ A razón de 27 dineros por carnero, para un total de 2.005 cabezas aportadas entre los cinco proveedores (AMB, Actas, 1463, fols. 12', 13, 62 y otros).

${ }^{205}$ AMB, Actas, 1432, fol. 60

209 AMB, Actas, 1463, fol. 61

210 AMB, Actas 1478, fol.28'. También se gestiona la financiación de las empresas de importación. En 1447 ordenaron devolver las 10 doblas que Francisco Martinez y Pedro González el Rico habian prestado cada uno a Fernando López de Yanguas para traer carne de la feria de Medina para abastecimiento de la ciudad (AMB, Actas, 1447, fol. 99).

21. AMB, Actas, 1447, fol. 109

212 AMB, Actas, 1441, passim. 
ducto, por encima de la naturaleza de las personas que se comprometieran a ello. Por eso, en 1436, ante la discusión entablada en el Regimiento sobre la conveniencia o no de que los oficiales intervinieran en el arrendamiento de la carne, su opinión era que pudiera realizar el suministro cualquier persona, fuera o no integrante del Concejo ${ }^{213}$. La defensa y promoción de sus intereses llevaria al procurador mayor a solicitar a los Reyes Católicos, en 1495, que se permitiera la participación del pueblo, a través de su persona, en la estipulación de precios que, hasta entonces, efectuaban exclusivamente los alcaldes y regidores ${ }^{214}$.

Pero una cosa era esa participación y otra muy distinta el hecho de que, a falta de carniceros, tuvieran que ser las propias vecindades quienes costearan y se hicieran cargo de la gestión de las tablas municipales. No faltaron los momentos en que se recurrió -o intentó recurrir - a este sistema. En 1441 el Concejo utilizó los fondos del Arca de Misericordia municipal y un préstamo de $205.000 \mathrm{mrs}$. que repartió entre todas las vecindades, para financiar la compra de carne (Cuadro $V$ ) ${ }^{215}$. En 1486, 1490 y 1496 (Cuadro V) las vecindades se comprometieron, en principio, y bajo diversas condiciones ${ }^{216}$, a abastecer los bancos de la ciudad que les fueran repartidos, buscando por su cuenta las personas que se habian de obligar. En todos los casos, este sistema de provisión se convirtió en un rotundo fracaso. Inmediatamente surgian voces discrepantes que preferian "comer la carne cara e como pudiese ser que no hacer emprestidos» ${ }^{217}$. Las negativas a asumir los préstamos y los repartos de las tablas eran instantáneas. La opinión general que acababa imponiéndose de modo mayoritario entre las vecindades era la de buscar carniceros o personas particulares que se hicieran cargo del abasto, aun a costa de la

${ }^{213}$ AMB, Actas, 1436, fol. 12:

${ }^{214}$ AGS, RGS, I-1495, fol. 278 (Madrid, 1495-l-10)

215 AMB, Actas, 1441, fol. 24

$\because$ En 1486, la condición que exigen es el destierro de los carniceros. En 1489, los oficiales tendrán que responder a cinco exigencias: privación del oficio mientras las vecindades tuvieran las carnicerias; expulsión de los ganados de los carniceros antiguos de los pastos municipales para que fueran utilizados por los nuevos abastecedores; traspaso de la alcabala a los nuevos carniceros; compromiso del Concejo de que durante 10 años no se tomarian como carniceros a los actuales sin consulta previa con los procuradores de las vecindades; $y$, por fin, liberación de la obligación de "correr las vacas". A todas ellas responden las autoridades positivamente, salvo a la tercera - «trabajarian en ellow- y a la última - "porque es preminençia de la çiudad"- La información de todos estos años, en AMB, Actas, 1486, fols. 25-38'; Idem, 1490, fols. 126-163; y 1496, fols. 64'- 69'.

${ }^{217}$ AMB Actas, 1441, fol. 25. En 1486, la collación de Santa María considera que es preferible dar las tablas a los carniceros que las quieran tomar antes que uandar en emprestidos" (Idem, Actas, 1486, fol. 36'). 
elevación de los precios ${ }^{218}$. El abastecimiento de los despachos de carne a cargo del vecindario y los repartimientos que debian efectuarse entre la población implicaban un pesado coste económico y social, que aún recaia de forma más grave sobre las collaciones más pobres: las alusiones de San Martín, San Pedro, Santa María la Blanca... a las dificultades que afrontaría la "gente pobre" de sus vecindades son enormemente expresivas ${ }^{219}$. Al final siempre terminó por imponerse una realidad: la incapacidad de las collaciones para gestionar debidamente las carnicerías y la necesidad de recurrir a la iniciativa privada.

En resumen, todos los procedimientos alternativos proyectados por el Concejo o no se llevaron a la práctica, o fracasaron, o, en el mejor de los casos, sólo sirvieron para mitigar las dificultades, pero nunca pudieron sustituir el sistema de obligados. Sin duda, éste fue el método más eficiente para promover y lograr el abastecimiento cárnico de la ciudad. La dificultad consistía en conseguir personas que estuvieran dispuestas a gestionarle. Por eso no extraña el profundo desosiego con que las autoridades municipales se enfrentaban cada año al aprovisionamiento de carne, un problema que parecia perennemente insoluble.

Han quedado en el tintero algunos otros aspectos vinculados al abastecimiento y consumo de carne en la ciudad del Arlanzón: la venta de carne viva, la cria de puercos, la caza, las caracteristicas del consumo de carne en un medio urbano y su reflejo socio-económico... Otras cuestiones, como la referida a la propiedad y derechos sobre las tablas e instalaciones carniceras o la concerniente a la diferenciación entre abastecedores, carniceros-comerciantes y asalariados, están planteadas, acordes con la información aportada por la documentación que se ha utilizado, en el nivel de hipótesis y quedan, por lo tanto, pendientes de solución. En conjunto, sin embargo, he procurado sistematizar aquellos datos, ya conocidos en parte, que reflejan los problemas de abastecimiento que, a

218 Es lo que se mantuvo en 1441 , como se ha visto en la nota anterior. Tambièn en 1486 alguna collación (Vieja Rua) sugiere que es preferible dar la carne a los carniceros, a cualquier precio, antes que de cualquier otra forma (AMB, Actas, 1486, fol. 37). En 1490, la vecindad de San Gil se opuso al reparto de bancos y opinó que se deberia dar 1 blanca más en el precio a los carniceros, aunque sólo fuera como pago por los servicios prestados (Idem, 1490, fol. 133). En 1496, el voto de las collaciones de San Llorente. San Nicolás y otras es "que se tomen los carniceros en el mejor precio que se pudiese hacer", pues ellas no estaban dispuestas a dar ningún banco (Idem, 1496, fol. 67').

${ }^{219}$ En 1486 los representantes de San Martin y San Pedro alegaban que ellos eran "gentes pobres", pero asumian lo que hiciera el resto de las vecindades (AMB, Actas, 1486, fol. 35). Diez años más tarde, los de Viejarrua, Santa María la Blanca y San Román decian que su "pobre gente" no daría más de un banco y éste sin garantias de ser bien abastado (Idem. Actas, 1496, fol. 67'). 
fines de la Edad Media, se generan en las ciudades castellanas en general y en Burgos en particular, la politica de estricto control de todas las instancias del mercado interior desarrollada por los Concejos y, en conexión con ello, las alternativas y sistemas aportados para su resolución. 


\section{CUADRO IV. TABLA DE PRECIOS DE LA CARNE}

Columna 1: carnero; Columna 2: vaca; Columna 3: cordero extremeño; Columna 4: oveja: Columna 5; cabra y cabrón; Columna 6: tocino: Columna 7: cabrito; Columna 8: ternera.

\begin{tabular}{|c|c|c|c|c|c|c|c|c|}
\hline FECHA & 1 & 2 & 3 & 4 & 5 & 6 & 7 & 8 \\
\hline $16-4-1379$ & $14 \mathrm{ds}$. & 1 mrs. & & & & & & \\
\hline Mayo/junio & $12 \mathrm{ds}$. & 9 ds. & & & & & & \\
\hline $17-9-1379$ & $13 \mathrm{ds}$ & $9 \mathrm{ds}$. & & & & & & \\
\hline 4-4-1388 & $8 \mathrm{bls}$. & 6 bls. & & & & & & \\
\hline $9-5-1388^{?}$ & 7 bis. & 5 bis. & 5 bls. & 5 bis. & 4 bis. & 4 bis. & & \\
\hline $26-5-1388$ & $6 \mathrm{bls}$. & $4 \mathrm{~b} / \mathrm{s}$. & & & & & & \\
\hline $8-7-1388$ & 5 bls. & 3 bls. & & 3 bls. & & & & \\
\hline $13-4-1398$ & $13 \mathrm{ds}$ & $8 \mathrm{ds}$. & 1 mrs. & & & & $15 \mathrm{ds}$. & \\
\hline $19-4-1398^{3}$ & $12 \mathrm{ds}$ & $8 \mathrm{ds}$. & & & & & & \\
\hline $2-5-1398^{4}$ & $12 \mathrm{ds}$ & $9 \mathrm{ds}$. & & & & & & \\
\hline $15-6-1398^{5}$ & $13 \mathrm{ds}$. & $9 \mathrm{ds}$. & & & & & & \\
\hline $30-11-1398$ & $15 \mathrm{ds}$. & 1 mrs. & & & & & & \\
\hline $22-4-1411^{6}$ & $20 \mathrm{crs}$. & 2 mrs. & & & & & & \\
\hline $5-5-1411$ & & $2 \mathrm{mrs}$. & $2 \mathrm{mrs}$. & 2 mrs." & & 2 mrs. & & \\
\hline $15-7-1411$ & $3 \mathrm{mrs}$. & $11 \mathrm{crs}$. & & & & & & \\
\hline $25-7-1411$ & $20 / 21 \mathrm{crs}$. & $\begin{array}{l}12 / 13 \\
\text { crs. }^{\circ}\end{array}$ & & & & & & \\
\hline $17-4-1423^{9}$ & $18 / 20 \mathrm{crs}$ & $\begin{array}{l}12 / 13 \\
\text { crs. }{ }^{10}\end{array}$ & $12 / 13 \mathrm{crs}$ & $12 / 13 \mathrm{crs}$ & $12 / 13 \mathrm{crs}$ & & & $\begin{array}{l}18 / 20 \\
\text { crs. }\end{array}$ \\
\hline $9-7-1426^{17}$ & $20 / 22$ crs. & $\mid \begin{array}{ll}14 & \text { crs. } / 5 \\
\text { bls. } & 13\end{array}$ & & $\mid \begin{array}{ll}14 & \text { crs. } / 5 \\
\text { bls. } & \end{array}$ & $\begin{array}{ll}14 & \text { crs./5 } \\
\text { bls. }\end{array}$ & & & \\
\hline $15-3-1427^{15}$ & $\begin{array}{l}19 \text { crs } / 3,5 \\
\text { mrs. }\end{array}$ & $\begin{array}{l}13 / 14 \\
\text { crs. }\end{array}$ & & & & & & \\
\hline $12-3-1429$ & 3 mrs. & $2 \mathrm{mrs}$ & & & & & & \\
\hline
\end{tabular}


JUAN A. BONACHIA HERNANDO

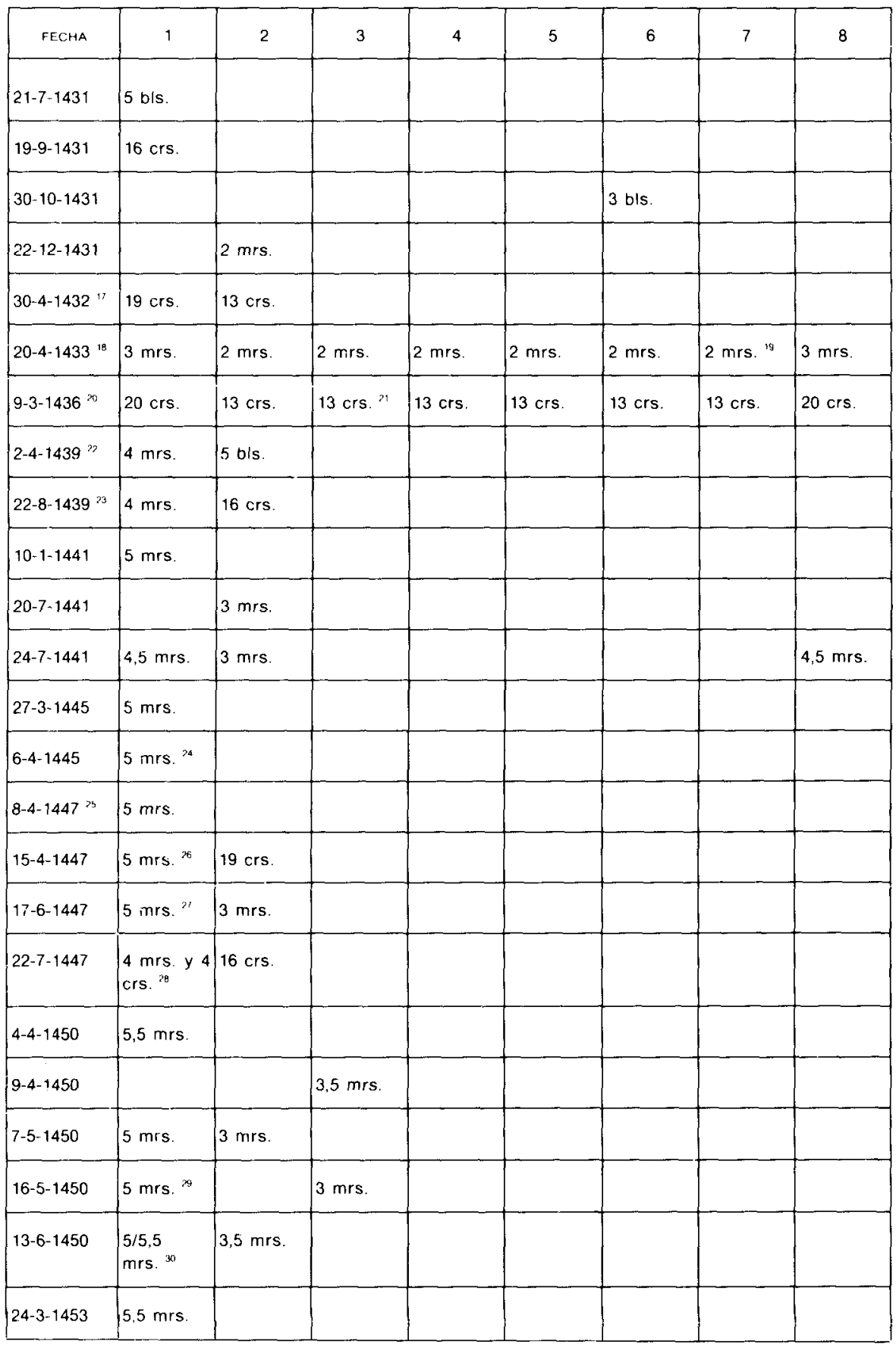

156 
Abastecimiento urbano, mercado local y control municipal: ...

\begin{tabular}{|c|c|c|c|c|c|c|c|c|}
\hline FECHA & 1 & 2 & 3 & 4 & 5 & 6 & 7 & 8 \\
\hline $5-4-1453$ & $5.5 \mathrm{mrs}$. & & & & & & & \\
\hline $30-4-1453$ & $5 \mathrm{mrs}$. & & & & & & & \\
\hline $1-5-1453$ & & & $19 \mathrm{crs}$. & & & & & \\
\hline $7-5-1453$ & $5 \mathrm{mrs}$. & & $19 \mathrm{crs}$. & & & & & \\
\hline $28-5-1453$ & $5 \mathrm{mrs}$. & $3,5 \mathrm{mrs}$. & $19 \mathrm{crs}$ & & & & & \\
\hline $5-7-1453$ & $5 \mathrm{mrs}$. & $3,5 \mathrm{mrs}$ & & & & & & \\
\hline $11-7-1453$ & $5 \mathrm{mrs}$ & $20 \mathrm{crs}$. & & & & & & \\
\hline $29-4-1458$ & & & $\begin{array}{l}3 \text { mrs., } 5 \\
\text { ds. }\end{array}$ & & & & & \\
\hline $30-6-1461^{37}$ & $7 \mathrm{mrs}$ & $4,5 \mathrm{mrs}$ & & $4,5 \mathrm{mrs}$. & $4,5 \mathrm{mrs}$ & & & \\
\hline 31-5-1462 & $10.5 \mathrm{mrs}$ & & $5,5 \mathrm{mrs}$. & & & & & \\
\hline 3-6-1462 & $6.5 \mathrm{mrs}$. & & $4 \mathrm{mrs}$. & & & & & \\
\hline $16-6-1462$ & & $\begin{array}{lll}4 & \mathrm{mrs} ., & 2 \\
\mathrm{crs} .\end{array}$ & & & & & & \\
\hline $21-8-1462$ & 6 mrs. ${ }^{33}$ & $\mid \begin{array}{l}4 \mathrm{mrs} . /^{34} \\
4 \mathrm{mrs} \text { y } 1 \\
\mathrm{crs} .\end{array}$ & & & & & & \\
\hline $30-12-1462$ & $6,5 \mathrm{mrs} .{ }^{35}$ & & & & & & & \\
\hline $15-1-1463$ & $7 \mathrm{mrs}$ & & & & & & & \\
\hline $1-2-1463$ & & & & & & 7 bls. & & \\
\hline 21-5-1463 & $7 \mathrm{mrs}$ & $5 \mathrm{mrs}$ & & & & & & \\
\hline $14-5-1465$ & $8 / 7 \mathrm{mrs} .{ }^{36}$ & & & & & & & \\
\hline $10-8-1465$ & & $5 \mathrm{mrs} .{ }^{37}$ & & & & & & \\
\hline $6-7-1471$ & $8 \mathrm{mrs}$ & & & & & & & \\
\hline $21-5-1476^{38}$ & $11 \mathrm{mrs}$. & & & & & & & \\
\hline $27-8-1476^{39}$ & $12 \mathrm{mrs}$. & & & & & & & \\
\hline
\end{tabular}


JUAN A. BONACHIA HERNANDO

\begin{tabular}{|c|c|c|c|c|c|c|c|c|}
\hline FEECHA & 1 & 2 & 3 & 4 & 5 & 6 & 7 & 8 \\
\hline $2-5-1478$ & & & & $7 \mathrm{mrs}$ & & & & \\
\hline $30-5-1478$ & $\mid \begin{array}{l}11,5 / 12 \\
\text { mrs. }\end{array}$ & $8.5 \mathrm{mrs}$. & & & & & & \\
\hline $9-6-1479$ & $13 \mathrm{mrs}$. & $9 \mathrm{mrs}$. & 9 mrs. ${ }^{44}$ & $9 \mathrm{mrs}$. & $9 \mathrm{mrs}^{13}$ & & & \\
\hline 5-6-1481 & $12 \mathrm{mrs}$ & $9 \mathrm{mrs}$ & & & & & & \\
\hline $31-8-1481$ & $11 \mathrm{mrs}$ & $8 \mathrm{mrs}$. & . & & & & & \\
\hline $21-6-1483$ & $10,5 \mathrm{mrs}$ & $7,5 \mathrm{mrs}$ & & & & & & \\
\hline $24-6-1483$ & 10,5 mrs. & $8 \mathrm{mrs}$. & & & & & & \\
\hline $5-3-1484$ & $10 \mathrm{mrs}$. & $7,5 \mathrm{mrs}$. & & & & & & \\
\hline $2-5-1485$ & $10.5 \mathrm{mrs}$ & $8 \mathrm{mrs}{ }^{47}$ & & & & & & $10,5 \mathrm{mrs}$. \\
\hline $18-5-1486$ & $\begin{array}{l}11,5 \\
\text { mrs. }\end{array}$ & $9 \mathrm{mrs}$. & & & & & & \\
\hline $4-6-1487$ 50 & $\begin{array}{l}12,5 / 13 \\
\text { mrs bi }\end{array}$ & $9 \mathrm{mrs}$. & & & & & & \\
\hline $27-5-1488$ & $\begin{array}{l}11 / 11,5 \\
\text { mrs }\end{array}$ & $8 \mathrm{mrs}^{53}$ & & & & & & \\
\hline $27-5-1490$ & $\begin{array}{l}10,5 / 11 \\
\text { mrs. }\end{array}$ & $\begin{array}{l}7,5 / 8 \\
\text { mrs. }\end{array}$ & & & & & & $\begin{array}{l}10,5 / 11 \\
\text { mrs. }\end{array}$ \\
\hline $15-6-1492$ & $12,5 \mathrm{mrs}$ & $9 \mathrm{mrs} .56$ & & & & & & \\
\hline $17-6-1493$ & $11,5 \mathrm{mrs}$. & $8 \mathrm{mrs}$ & & & & & & \\
\hline $16-5-1494$ & $11 \mathrm{mrs}$. & $7,5 \mathrm{mrs}$ & & & & & & \\
\hline $3-3-1495$ & $10.5 \mathrm{mrs}$ & $7.5 \mathrm{mrs}^{5}{ }^{5}$ & & & & & & to, $5 \mathrm{mrs}$ \\
\hline $5-5-1496$ & $11,5 \mathrm{mrs}$ & $8,5 \mathrm{mrs}$. & & & & & & \\
\hline $1-7-1497$ & $12 \mathrm{mrs}$ & $9 \mathrm{mrs}^{39}$ & & & & & & \\
\hline
\end{tabular}

'Pesos expresados en cuartas; el tocino en libras

- Precios establecidos hasta el Domingo de la Trinidad.

${ }^{3}$ Desde finales de este mes en adelante.

${ }^{4}$ Por adición de la sisa: un dinero por cuarta.

${ }^{5}$ Igualmente por adición de un dinero por cuarta a causa de la sisa.

${ }^{6}$ Hasta que sea merced de la ciudad. 
"Según que vale la vaca"

${ }^{8}$ Las cantidades más pequeñas, tanto en carnero como en vaca, hasta Navidad. Las más altas, desde Navidad a Carnestolendas.

${ }^{9}$ Por un año. hasta Carnestolendas de 1424.

10 Tanto en vaca como en carnero. la cantidad más baja hasta Navidad, y la más alta desde Navidad a Carnestolendas.

" "Ternera según carnero", "cordero extremeño, oveja, cabrón y cabra, según la vaca".

${ }^{12}$ Hasta Carnestolendas de 1427.

${ }^{13}$ Vid. notas 8 y 10.

"Precios de la oveja y cabrón, "según la vaca".

15 Desde Pascua de Resurrección de 1427 a Carnestolendas de 1428.

${ }^{16}$ Precios más altos para vaca y carneros, desde Navidad a Carnestolendas

Hasta Pascua de Cincuesma.

18 De 1 de mayo de 1433 a Carnestolendas de 1434 y de ahi en dos años.

19 "Las otras carnes a precio de vaca".

${ }^{20}$ Durante cuatro años.

"La ternera, como la cuarta del carnero; las ovejas, cabrones, cabras, corderos y libra de tocino, según la vaca.

22 "Por el tiempo que a esta cibdad ploguiese".

${ }_{23}$ Desde mediados de septiembre.

${ }^{24}$ Que no pesen cabeza, porque era mucho.

${ }^{25}$ Por ocho dias.

${ }^{26}$ Con cabeza.

"Sin cabeza ni menudos.

${ }^{28}$ Sin cabeza ni menudos.

29 Desde Pascua en adelante.

${ }^{30}$ El precio más barato hasta Año Nuevo; el más caro, desde Año Nuevo a Carnestolendas.

${ }^{31}$ A partir de aqui, vid. la duración de contratos y precios en Cuadro II.

${ }^{32}$ Hasta Todos los Santos sin cabeza ni menudos; desde Todos los Santos, con cabeza.

${ }^{33}$ Hasta Navidad, 9 carneros por banco, sin pesar cabeza ni menudos; Desde Navidad a Carnestolendas, 6 carneros por banco pesando cabezas.

${ }^{34}$ El primer precio hasta Navidad; el segundo, más alto, de Navidad a Carnestolendas.

35 "Y que se pesen las cabezas".

${ }^{36}$ La primera tasa, hasta finales de mayo, con cabezas y asaduras; la segunda, desde mayo

a San Juan, con cabeza pero sin asaduras.

it Los lomos de la vaca, a $8 \mathrm{mrs}$.

${ }^{38}$ Hasta San Juan.

${ }^{39}$ Hasta San Andrés.

to Desde mediados de septiembre a 5 de octubre.

${ }^{41}$ Precio más caro hasta Todos los Santos; se eleva a partir de entonces hasta San Juan.

${ }^{42}$ Los lomos de las vacas al precio del carnero.

${ }^{43}$ Los lomos de las vacas, al precio del carnero.

${ }^{44}$ Desde Pascua Florida hasta San Juan de 1480, al precio de la vaca.

4s Ovejas y cabrones, desde San Miguel a Carnestolendas, al precio de la vaca.

${ }^{46}$ Hasta San Juan de 1484.

47 Terneras y lomos de las vacas, al peso y precio del carnero.

48 Hasta San Juan de 1487.

${ }^{49}$ Que con el carnero pesen la cabeza.

${ }^{50}$ Hasta San Juan de 1488.

${ }^{51} 12,5 \mathrm{mrs}$. hasta fines de agosto; desde 1 de septiembre hasta San Juan a $13 \mathrm{mrs}$.

52 $11 \mathrm{mrs}$ : desde mediados de septiembre a mediados de noviembre del primer año y durante todo el segundo año.

${ }_{53}$ Los lomos de la vaca, al precio del carnero.

${ }^{54}$ Los precios más caros el primer año; los más baratos, el segundo. 
so Terneras y lomos de las vacas, al precio del carnero.

${ }^{56}$ Precios de la vaca y carnero vigentes para el primer año. Lomos de la vaca, a precio del carnero.

57 Los lomos de la vaca a precio del carnero.

s6 Ambas tasas, vaca y carnero, sin sisa (1 blanca).

${ }^{59}$ Los lomos de la vaca, a precio de carnero. 
Abastecimiento urbano, mercado local y control municipal:

\begin{tabular}{|c|c|c|c|c|}
\hline \multirow{3}{*}{ COLLACIONES } & 1441 & \multicolumn{3}{|c|}{1496} \\
\hline & \multirow{2}{*}{$\begin{array}{l}\text { REPARTIMIENTO } \\
\text { DE MRS PARA } \\
\text { "TRAER CARNE" }\end{array}$} & \multicolumn{3}{|c|}{ REPARIO DE EANCOS } \\
\hline & & TOTAL & VACA & CAFNERO \\
\hline San Juan & 20.000 & 3 & 2 & 1 \\
\hline San Gil & 15.000 & 3 & 2 & 1 \\
\hline San Llorente & 25.000 & 2 & 1 & 1 \\
\hline Santa Maria & 20.000 & 3 & 1 & 2 \\
\hline Santiago & 15.000 & 1 & --- & 1 \\
\hline San Nicolás & 30.000 & 3 & 1 & 2 \\
\hline San Esteban & 25.000 & 2 & 1 & 1 \\
\hline San Román & 25.000 & $3^{:}$ & 1 & 2 \\
\hline Viejarrua & $10.000^{3}$ & - . & $-\ldots$ & - \\
\hline San Martin & 15.000 & 4 & 2 & 2 \\
\hline Santa Maria La Blanca & 5.000 & - & - & - \\
\hline
\end{tabular}

- Junto a Viejarrúa y Santa Maria la Blanca.

2 "Sin los moros". 